\title{
MINERALOGIA E CRISTALOGRAFIA DO DIAMANTE DO TRIÂNGULO MINEIRO *
}

\author{
Cirano Rocha Leite \\ Faculdade de Filosofia, Ciências e Letras de \\ Araraquara, S. Paulo
}

\section{N D I C E}

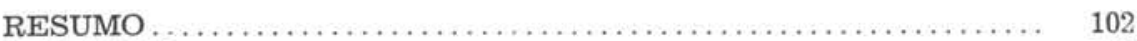

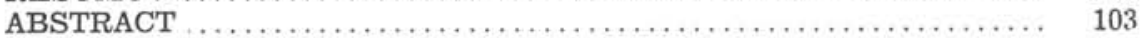

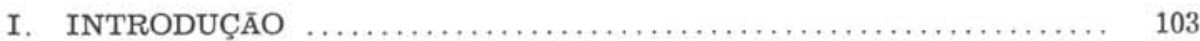

1. Histórico e trabalhos anteriores ..................... 104

2. Situação geográfica e geológica ........................... 104

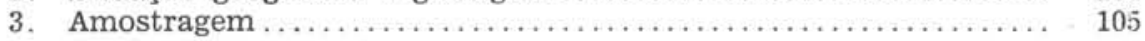

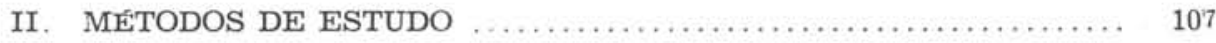

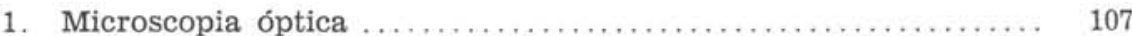

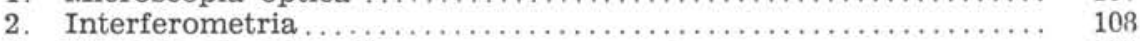

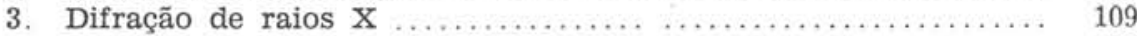

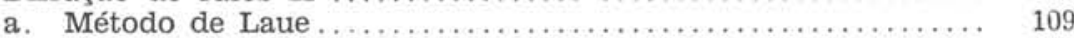

b. Método do pó ................................... 109

c. Método da precessão ...................................... 109

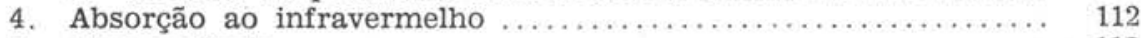

5. Fluorescência ................................. 112

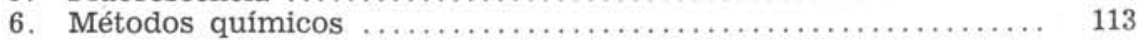

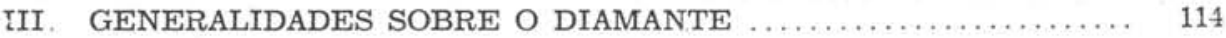

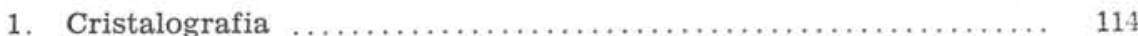

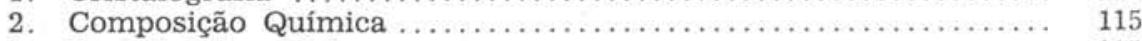

3. Propriedades Físicas ................................ 115

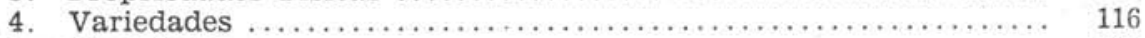

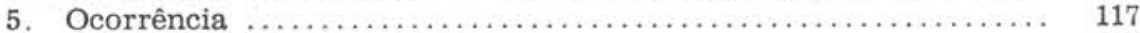

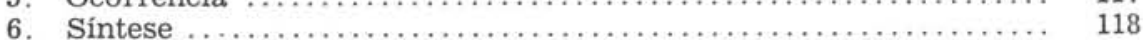

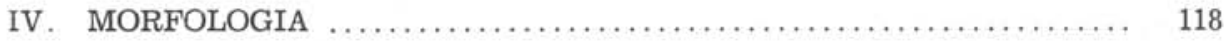

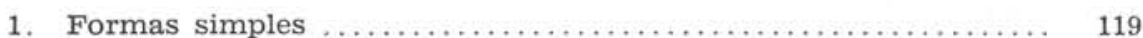

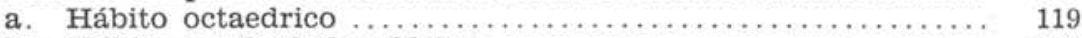

b. Hábito rombododecaédrico ........................ 120

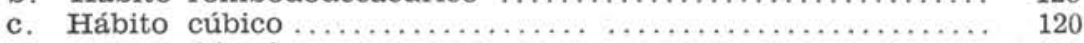

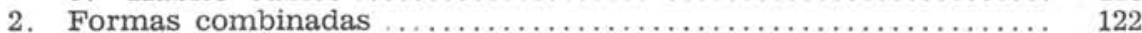

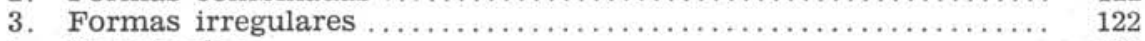

4. Germinados ...................................... 122

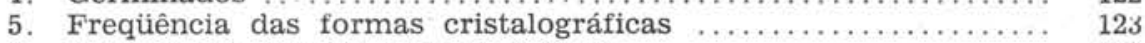

6. Origem das formas cristalográficas .................... 124

Tese apresentada em 1969 à Faculdade de Filosofia, Ciencias e Letras da Universidade de São Paulo para a obtençāo do título de Doutor em Ciências. 
V. FIGURAS E ESTRUTURAS DE SUPERFfCIE ................ 126

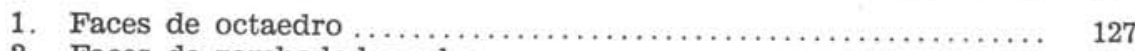

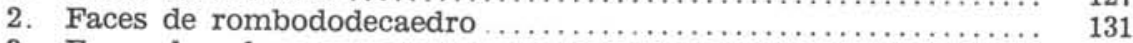

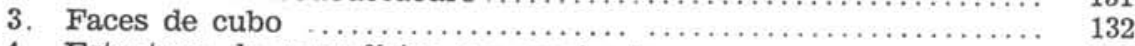

4. Estrutura de superfícies em geminados ................. 132

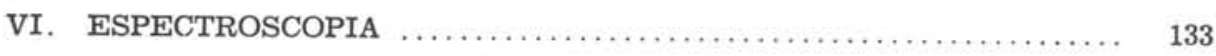

1. Espectrografia de absorção as irradiações infravermelhas ..... 133

2. Fluorescência ao ultravioleta .......................... 136

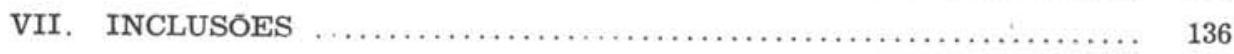

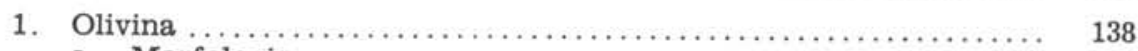

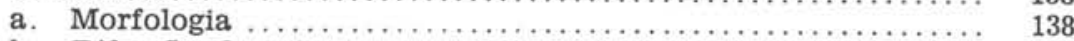

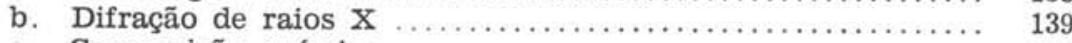

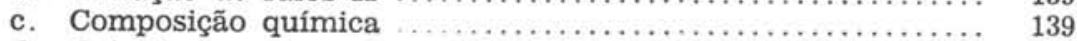

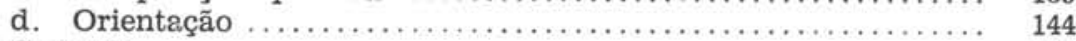

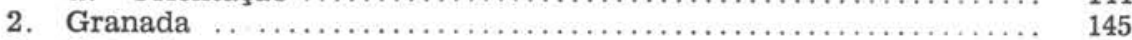

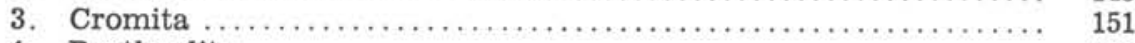

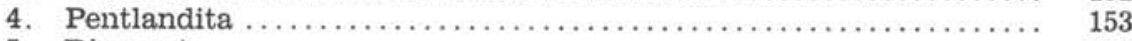

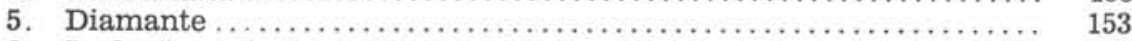

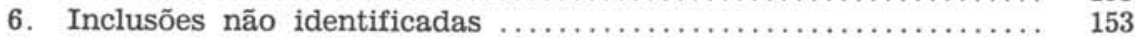

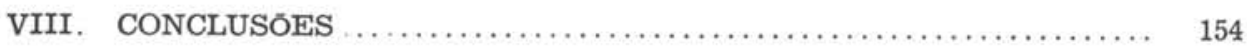

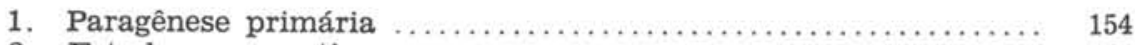

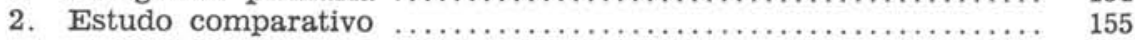

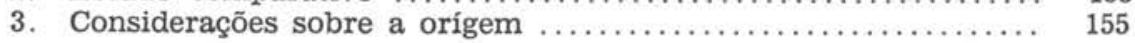

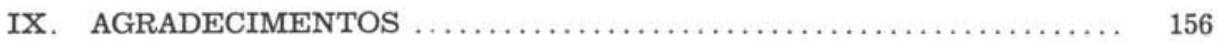

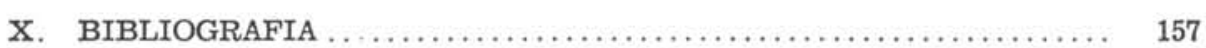

\section{RESUMO}

O presente trabalho procura caracterizar o diamante do Triângulo Mineiro, através de sua morfologia, figuras e estruturas de superfície, propriedades espestroscópicas (absorção ao IV e fluorescência ao UV) e, principalmente, pelas inclusões minerais, estudo que poderá conduzir, com maior segurança, os trabalhos geológicos futuros, em busca da matriz primária, ainda desconhecida

0 estudo morfológico revelou a predominância do hábito rombododecaédri$\mathrm{co}$, entre as formas simples presentes, sendo também freqüentes os geminados (33\% do total). A predominância da forma rombododecaédrica, com faces arredondadas, é explicada, aqui, como resultado de dissolução natural, em ambientes oxidantes. $\mathrm{O}$ rombododecaedro - forma de equilíbrio durante tal processo - foi deduzido pela variação de velocidade de dissolução, levando-se em conta a estrutura cristalina do diamante. As figuras de superficie são, em linhas gerais, as mesmas já observadas em diamantes de outras procedências, tendo-se notado sòmente algumas estruturas e figuras superficiais ainda não descritas. A origem destas figuras pode ser admitida como conseqüência de corrosão natural do diamante, o que se confirma pela sua presença em sólidos de clivagem.

Os diagramas de absorção ao infravermelho, acusaram uma freqüência anômala de diamantes do tipo Ib, raros entre os diamantes naturais. Esta observação deve ser confirmada por estudos futuros, e talvez constitua uma das principais características do diamante do Triângulo Mineiro.

As inclusões minerais, identificadas através da difração de raios X (método da precessão): forsterita, piropo, magnesiocromita e pentlandita, sugerem pro- 
cessos genéticos ligados ao magmatismo ultrabásico. A presença de efeitos secundários no hospedeiro (birrefringência anômala e fraturas de tensão, além do fato de estas inclusões ocorrerem epitàxicamente orientadas no diamante, afastam qualquer hipótese de preenchimento secundário.
A paragênese primária, indicando o equilíbrio

$$
\begin{gathered}
\text { forsterita }+ \text { espinélio }+ \\
\text { coesita } \longleftrightarrow \text { piropo }
\end{gathered}
$$

talvez permita estimar as condições de pressão e temperaturas ambientes durante a cristalização do diamante.

\section{ABSTRACT}

The purpose of this work is to characterize the diamond from the "Triângulo Mineiro" region (Minas Gerais) according to its morphological features; surface structures and surface figures; spectrographic properties (IV absorption and UV fluorescence) and specially by the recognition of its mineral inclusions. These crystallographic data may be important to guide, with greater sucess, the future geological work searching the diamond matrix-rock, until unknown in that region.

The morphological study revealed a predominance of the rhombododecahedral habit among the single forms presented by the diamond crystals. It is very frequent also the occurrence of diamond twinned crystals $(33 \%$ of the observed samples). The predominance of the rhombododecahedral habit, with both rounded faces and edges, is explained as a result of a natural dissolution process in a oxidizing media. The rhombododecahedral form was deduced here as the equilibrium form during that process. It was considered in that assumption the dissolution velocities changes, according to the diamond crystal structure.

The surface figures and surface structures are, on its general features, the same as the described ones on diamonds from other localities. Some of them, however, may be not still mentioned. The origin of some of those figures should be admitted as a result of crystal dissolution, by its presence on natural clivage surfaces.

The infrared absorption diagrams showed a anomalous occurrence of the type $\mathrm{Ib}$ diamonds. That kind of stone is very rare amongst the natural ones and that property may be the more remarkable characteristic of the diamond from the "Triângulo Mineiro".

The mineral inclusions, identified by $\mathrm{x}$-ray diffraction (precession method) forsterite, pirope, magnesio-chromite and pentlandite - sugests a genetic process very close to the ultrabasic rocks. The secondary effects observed on the host crystal (anomalous birefringence and tension fractures) and the epitaxic development of the inclusions in the diamond, indicates, on the other hand, that those minerals were enclosed during the diamond crystal growing.

The primary paragenesis, revealed by that syngenetic inclusions, sugests the equilibrium:

$$
\begin{aligned}
& \text { forsterite }+ \text { spinel }+ \\
& \text { coesite } \longrightarrow \text { pirope, }
\end{aligned}
$$

that may be applied to estimate the pressure and temperature conditions in the time of the diamond crystallization.

\section{INTRODUÇÃO}

Desde o século passado, procurouse elucidar o problema da origem do diamante brasileiro, principalmente através de métodos exclusivamente geológicos. As controvérsias que até hoje perduram talvez pudessem ser explicadas pela falta de um estudo mineralógico inicial, cujos resultados orientassem, com maior segurança, os trabalhos geológicos posteriores. 
Com o intuito de fornecer alguns dêsses elementos, ainda pràticamente omissos na literatura geológica nacional, elaborou-se o presente trabalho, que procura caracterizar o diamante do Triângulo Mineiro, através de sua morfologia, propriedades físicas e, especialmente, de suas inclusões minerais. Êstes dados poderão estabelecer, dentro de certos limites, as condições ambientes quando de sua formação, além de permitir a comparação dos diamantes de diversas áreas conhecidas.

\section{Histórico e trabalhos anteriores}

As ocorrências de diamante, em Minas Gerais, são conhecidas desde o início do século XVIII (Reis, 1959), e os núcleos iniciais de exploração desenvolveram-se na região de Diamantina, ao $\mathrm{N}$ do Estado. A legislação mineira da época, forçava a exploração clandestina em grande escala e muitos garimpeiros, para fugirem à fiscalização, embrenhavam-se mais para o interior, surgindo, assim, novos centros de garimpo, a W do Rio São Francisco, na região do Triângulo Mineiro.

Nessa área, o diamante encontra-se disseminado numa extensão de aproximadamente $100.000 \mathrm{~km}^{2}$ (Leonardos, 1956) e, talvez por essa razão, essas ocorrências não sejam tão conhecidas geològicamente, como na área de Diamantina. Contudo, mesmo assim, são inúmeros os estudos sôbre a geologia do diamante na região do Triângulo.

Derby (1882), estudando as ocorrências de Diamantina (São João da Chapada), relaciona os processos genéticos com rochas ácidas e extrapola essas considerações para os depósitos do Triângulo. No entanto, mais tarde (1898), sugere que as ocorrências de Água Suja (atual Romaria), e talvez os de Abaeté, possam ligar-se a eruptivas básicas. As jazidas de Água Suja já haviam sido anteriormente descritas por Campos (1891) e Hussak (1894).

Em 1906, Hussak tentou relacionar a origem do diamante, na região, com rochas de composição semelhante ao kimberlito: magnetita-piroxenito de $\mathrm{Ca}$ talão (Goiás) e a rocha tufácea de Uberaba. Porém, desde que essas rochas são estéreis em diamante, deixou o problema em suspenso.

Rimann (1915, 1917 e 1931) descreveu a ocorrência de chaminés ultrabásicas do tipo kimberlítico, na Serra da Mata da Corda e em diversos pontos do Triângulo, acreditando serem as responsáveis pelo diamante do oeste de Minas Gerais, no que foi apoiado por Maack (1926 e 1932).

Guimarães (1931, 1932 e 1934), e Bôa Nova (1932), contestaram as considerações de Rimann: as chaminés seriam, na realidade, lençóis de eruptivas básicas (rochas tufíticas e brechiformes), pobres em olivina e estéreis em diamante.

Freyberg (1932 e 1934), em estudo sôbre a geologia e recursos minerais da região, confirmou as observações de Rimann e Maack, com relação às chaminés da Serra da Mata da Corda, e supôs que o magma se haja manifestado em diversos períodos. Em primeiro lugar, teríamos os derrames, no Triássico e, posteriormente, no Cretáceo, as erupções, com as quais estariam ligadas as chaminés.

Guimarães (1965), utilizando elementos já citados em trabalhos anteriores, classifica, de modo geral, as ocorrências diamantíferas brasileiras, dentro de sequiência metamórfica, como depósito de epizona. Considera improvável que os processos genéticos, na região do Triângulo, estejam ligados a magmatismo básico ou ultrabásico.

Como se vê, de 1934 até o presente, o panorama permanece essencialmente o mesmo.

\section{Situação geográfica $e$ geológica}

A região do Triângulo Mineiro, compreende a área delimitada pelos Rios Grande e Paranaíba, estendendo-se, a E, 


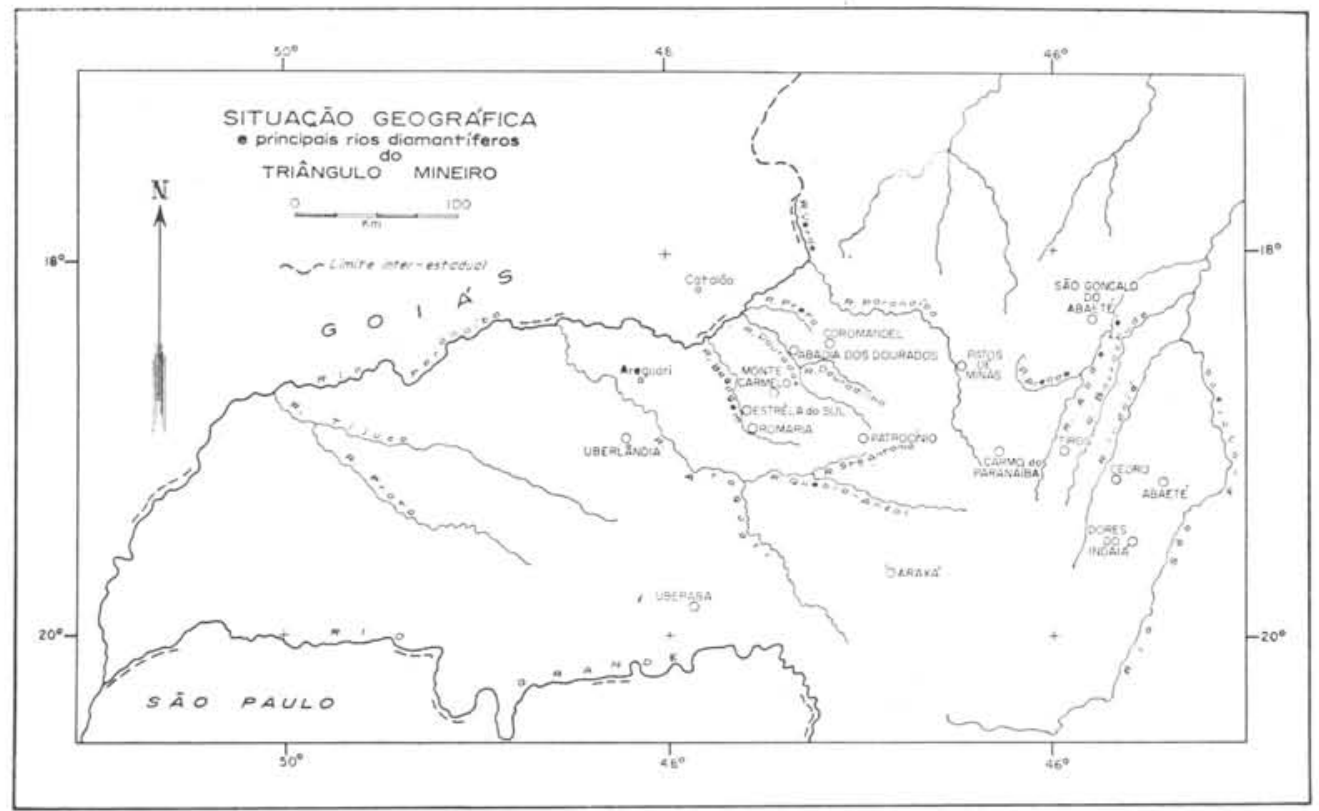

Figura 1 - Situação geográfica e principais rios diamantíferos do Triângulo Mineiro

até o Rio São Francisco e, ao S, até o paralelo de $20^{\circ}$, aproximadamente.

A drenagem da área se faz pelas bacias do Paraná ou do São Francisco, sendo o divisor formado pela Serra da Mata da Corda e Serra da Canastra. A altitude é variável entre 400 e $1200 \mathrm{~m}$ acima do nível do mar, e o relêvo é ligeiramente ondulado, tornando-se mais acidentado a E. O diamante é, aí, encontrado nas aluviões recentes dos rios ou terraços fluviais.

Os atuais centros de produção diamantífera e os principais rios explorados, estão representados na Figura 1.

A geologia da área (Hasui, 1967) é representada, predominantemente, pelas formações Cretáceas e Cenozóicas, assentadas, em discordância angular, sôbre o Complexo Cristalino.

A Tabela 1 mostra, resumidamente, a coluna geológica regional, podendo-se ver, no mapa geológico (Figura 2), a distribuição geográfica das unidades estratigráficas.

$\mathrm{O}$ Complexo Cristalino aflora a NE e a SE do Triângulo (Grupo Araxá e Grupo Canastra), aparecendo, ainda, na região do alto Paranaíba (Grupo Araxá, Grupo Canastra e Grupo Bambui). Sôbre êle, depositam-se as formações Eocretáceas (Formação Botucatu e Formação Areado), recobertas por eruptivas básicas (Formação Serra Geral) e ultrabásicas (Formação Patos). Os sedimentos fluviais da Formação Uberaba e Grupo Bauru (Neocretáceos), foram precedidos de vulcanismo alcalino, responsáveis pelos distritos de Tapira, Araxá, Salitre, Serra Negra e o de Catalão (em Goiás). Depósitos aluviais, coluviais e eluviais, inconsistentes, representam, na região, o Cenozóico.

\section{Amostragem}

A quase totalidade dos diamantes estudados foi adquirida de intermediários (compradores), em centros de comércio diamantário, o mais próximo possível dos garimpos: Araguari, Estrêla do Sul, Romaria, Monte Carmelo, Abadia dos Dourados, Coromandel, Patrocínio, Patos de Minas, São Gonçalo do Abaeté, Tiros, Cedro do Abaeté, Abaeté e Dôres do Indaiá. A aquisição direta, que seria ideal, para maior autenticidade da amos- 
TABELA 1 - Coluna geológica geral (segundo Hasui, 1967)

\begin{tabular}{|c|c|c|c|c|c|c|}
\hline \multirow{2}{*}{\multicolumn{2}{|c|}{$\begin{array}{c}\text { Unidade } \\
\text { Cronogeológica }\end{array}$}} & \multicolumn{3}{|c|}{ Unidade Litoestratigráfica } & \multirow{2}{*}{ Litologia e diacordâncias } & \multirow{2}{*}{ Ambiente } \\
\hline & & Grupo & Formações & Membro & & \\
\hline \multicolumn{2}{|l|}{ Cenozóico } & & & & $\begin{array}{l}\text { Areias inconsolidadas. Cas- } \\
\text { calhos, cangas limoníticas. } \\
\text { Depósitos de lagoas. }\end{array}$ & $\begin{array}{l}\text { Aluvial } \\
\text { Eluvial } \\
\text { Coluvial }\end{array}$ \\
\hline \multirow{6}{*}{ Cretáceo } & \multirow{3}{*}{ 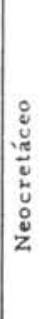 } & Bauru & & & $\begin{array}{l}\text { Arenitos e conglomerados } \\
\text { e, subordinadamente, a:- } \\
\text { gilitos, folhelhos papiráceos, } \\
\text { rochas silicosas e calcários }\end{array}$ & Fluvial \\
\hline & & & Uberaba & & $\begin{array}{l}\text { Arenitos a conglomerados e, } \\
\text { subordinadamente, argilitos } \\
\text { e siltito v vulcânicos. }\end{array}$ & Fluvial \\
\hline & & & & & Rochas alcalinas & \\
\hline & \multirow{3}{*}{ 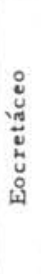 } & \multirow{3}{*}{ 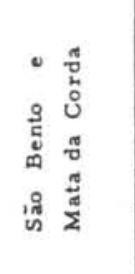 } & $\begin{array}{l}\text { Serra } \\
\text { Geral } \\
\text { Patos }\end{array}$ & & $\begin{array}{l}\begin{array}{l}\text { Basaltos e arenitos intertra } \\
\text { peanos }\end{array} \\
\begin{array}{l}\text { Derrames ultrabásicos e in - } \\
\text { tercalaçöes piroclásticas }\end{array}\end{array}$ & Continental \\
\hline & & & Botucatu & Botucatu & Arenitos & Eólico \\
\hline & & & Areado & & $\begin{array}{l}\text { Arenito } s \text {, siltitos, folhelhos } \\
\text { pirobetuminosos }\end{array}$ & Fluvial \\
\hline \multicolumn{2}{|c|}{$\begin{array}{c}\text { Pré-Cambriano } \\
(?)\end{array}$} & $\begin{array}{l}\text { Bambuí } \\
\text { Canastra } \\
\text { Araxá }\end{array}$ & & 77 & $\begin{array}{l}\text { Ardó sias, metasiltitos, arcó- } \\
\text { seos, calcários, filitose quart } \\
\text { zitos. Itabiritos, xistos, gnais } \\
\text { ses. Anfibolitos, granitos } \\
\text { pegmatitos }\end{array}$ & $\begin{array}{l}\text { Geo- } \\
\text { Sinclinal }\end{array}$ \\
\hline
\end{tabular}

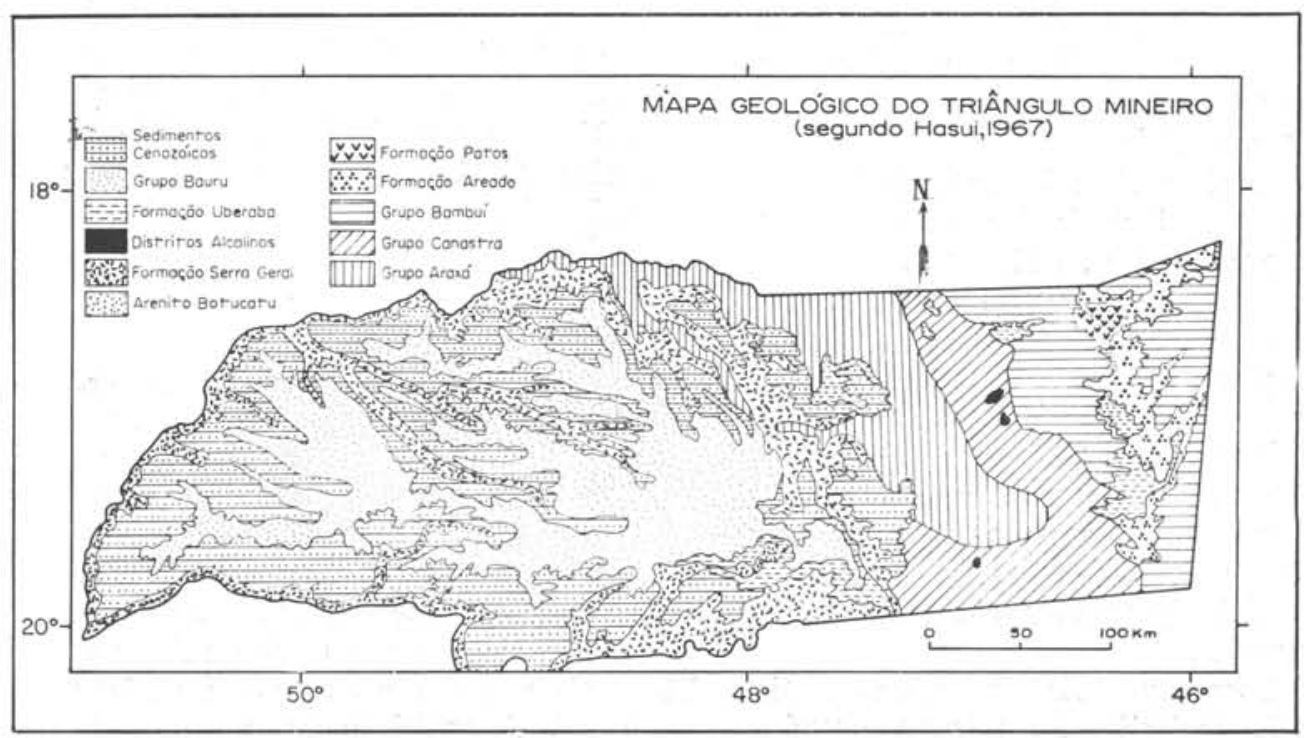

Figura 2 - Mapa geológico do Triângulo Mineiro (segundo Hasui, 1967). 
tragem, é quase impraticável: o garimpeiro só se desfaz do seu material, após um grande número de ofertas. No entanto, tôda a precaução foi tomada, com o intuito de não se contaminar o lote estudado, com diamantes de outras áreas diamantíferas mais distantes (Mato Grosso ou norte de Minas Gerais).

Desta forma, foi possível dispor de, aproximadamente, 230 amostras, tôdas elas do tipo industrial (diamantes com inclusões ou defeitos), e de pêso variável entre 0,05 a 2,00 quilates métricos.

A Figura 3 mostra a distribuição do material estudado, levando-se em consideração o pêso.

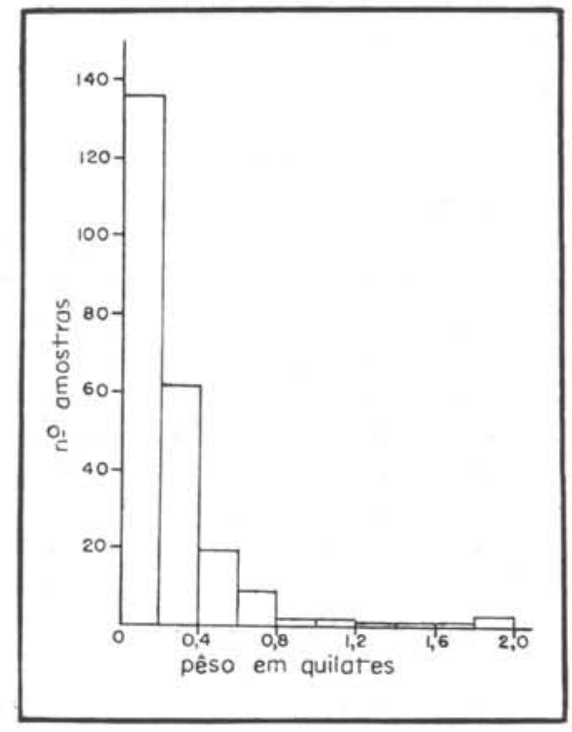

Figura 3 - Características da amostragem.

\section{MÉTODOS DE ESTUDO}

Na elaboração da parte experimental do presente trabalho, procurou-se, sempre que possível, aplicar métodos de estudo não destrutivos, com o objetivo de se preservarem as amostras, para trabalhos posteriores. Dentre êstes métodos, tentou-se, inicialmente, utilizar a microscopia de raios $\mathrm{X}$ (microrradiografia), que elimina os inconvenientes da reflexão total, quando o diamante é examinado à lupa ou ao microscópio, por luz transmitida. A microrradiografia já foi aplicada com êxito, no estudo de precipitados em diamantes (Shah e Lang, 1959). No entanto, o processo utilizado, topografia de raios X (Lang, 1958), requer a preparação prévia da amostra, em lâmina delgada, sendo, portanto, semidestrutivo. Diante disto, procurou-se empregar outros processos de microrradiografia: contacto, projeção ou câmara obscura (Poen, 1955), que possibilitam a radiografia de amostras brutas. Porém, a grande transparência do diamante aos raios $\mathrm{X}$, permitindo que a radiação difratada pelo cristal também impressione o filme, prejudica o contraste das radiografias, o que impediu, por enquanto, a aplicação dêste método no presente estudo. Talvez, em amostras mais favoráveis, com faces planas e paralelas, a microrradiografia possa ser utilizada, com sucesso.

A goniometria de reflexão também foi tentada, no estudo morfológico do diamante, sendo utilizado o aparelho teodolítico, de dois círculos. As medidas dos ângulos diedros foram, no entanto, impraticáveis, pois com exceção da face de octaedro, as faces das demais formas se apresentam sempre arredondadas e irregulares, refletindo contìnuamente em grandes intervalos angulares.

\section{Microscopia óptica}

O exame óptico, à lupa ou ao microscópio polarizador, foi importante, principalmente no estudo morfológico e na observação de figuras e estruturas de superfície do diamante, sendo também aplicado como método auxiliar, nos trabalhos de identificação de suas inclusões.

A microscopia óptica, segundo a técnica convencional, requer a preparação da amostra, em lâminas delgadas (para luz transmititida) ou secções polidas 
(para luz refletida), o que resulta na sua destruição parcial. Com o objetivo de realizar o estudo óptico, conservando-se os exemplares intactos, teve-se de, inicialmente, contornar o problema da reflexão total, provocada pelo alto índice de refração do diamante, o que se conseguiu examinando-se as amostras imersas em líquidos de alta refringência. Para isto, construiu-se um pequeno recipiente, colando-se um aro metálico de $0,5 \mathrm{~mm}$ de altura por $2,0 \mathrm{~cm}$ de diâmetro, sôbre uma lâmina de vidro. Os líquidos inicialmente utilizados, como meio de imersão, foram o 1-monobromonaftaleno $(\mathrm{n}=$ $1,658)$ e o óleo de canela $(\mathrm{n}=1,600)$. Porém, a instabilidade dêstes líquidos, levou a substituí-los por nujol ( $\mathrm{n}=$ $1,453)$, sem grande prejuízo nas observações.

Outro artifício usado para melhorar as condições de estudo, foi adaptar o microscópio utilizado (Standard Universal Zeiss), de modo a obterem-se iluminação e contraste desejáveis, principalmente para a fotomicrografia. Tais condições foram conseguidas empregando-se luz convergente e deslocando-se a posição do condensador, tanto vertical como horizontalmente. Este procedimento permitiu utilizar os raios refletidos internamente no diamante, para melhorar a sua própria iluminação.

Com êstes recursos, foi possível observar as inclusões, no interior do diamante, e obter informações sôbre a sua morfologia, orientação, propriedades ópticas, bem como a sua influência nos cristais hospedeiros (fraturas de tensão e birrefringência anômala).

Os índices de refração das inclusões, utilizados para a sua perfeita identificação, foram determinados com o sacrifício de alguns exemplares de diamante. Os cristais incluídos, depois de destacados do hospedeiro e colocados na extremidade de capilares de vidro, foram imersos em líquidos de refrigência conhecida e, aplicando-se a técnica descrita por Rosenfeld (1950), determinaram-se todos os seus índices, utilizando-se sempre o mesmo cristal.
Nos diamantes cujas faces se apresentavam suficientemente planas e regulares, empregou-se a microscopia por luz refletida, no estudo de figuras e estruturas de superfície. Considerando-se, porém, a raridade dêstes casos, tal técnica foi pouco utilizada.

\section{Interferometria}

Aplicando-se a microscopia óptica, cujos recursos são limitados, não se pode distinguir, no plano de observação, pormenores com dimensões inferiores a $\lambda / 2$, sendo $\lambda$ o comprimento de onda da luz utilizada. No entanto, mesmo com meios ópticos, podemos observar desníveis nesse plano, da ordem de 10 $\AA$, ou seja, $\lambda / 500$, para a luz verde da lâmpada de mercúrio (Tolansky, 1960). Estas medidas são possíveis através de métodos interferométricos e a sua aplicação, na microtopografia de superficies polidas, é importante, no estudo do crescimento cristalino e na investigação de propriedades mecânicas (clivagem e dureza de abrasão ou endentação) de cristais ou ligas metálicas. Estudos dêste tipo foram realizados, para a interpretação do desenvolvimento das cavidades triangulares (trígonos), que ocorrem naturalmente, nas faces (111) do diamante. Muitas dessas figuras, assemelhamse a pirâmides negativas de base triangular, e os dados interferométricos permitiram o cálculo dos índices (hkl) das faces dessas pirâmides.

O método da interferometria utiliza o mesmo princípio que explica a formação de franjas de interferência, produzidas pela reflexão de raios luminosos, nas superfícies de películas finas. Desta forma, cobrindo-se a superfície de um cristal com uma lamínula de vidro, a película de ar entre o cristal e a lamínula, desde que suficientemente fina, produzirá, ao microscópio e com luz monocromática refletida, franjas de interferência cuja configuração irá depender da superfície do cristal (supõe-se que a lamínula seja perfeitamente plana e lisa). Esta figura é, na realidade, um verdadeiro mapa to- 
pográfico da superfície cristalina, sendo, a eqüidistância entre as curvas de nível, igual a $7 / 2$.

A interpretação da microtopografia, a partir da figura interferométrica é imediata, desde que se conheça o comprimento de onda da luz utilizada.

No presente estudo, aplicou-se um processo de interferometria relativamente recente (Nomarski e Weill, 1955), que utiliza a interferência de duas imagens polarizadas, sendo uma tomada como plano de referência para outra. Êste processo não oferece a precisão de outros, como os descritos por Tolansky (1960), mas apresenta como vantagem, a facilidade da preparação da amostra, pois dispensa a cobertura do cristal com lamínulas e a prateação do conjunto, necessária para melhor reflexão.

A microtopografia do diamante foi realizada ao microscópio metalográfico (Reichert Metatest), com o interferômetro de polarização colocado entre o iluminador opaco e a objetiva. As duas imagens polarizadas são produzidas por um prisma duplo de quartzo, sendo cada um ligeiramente deslocado e inclinado em relação a outro. A formação da figura interferométrica se dá quando os polarizadores do microscópio estão cruzados. Para a obtenção de luz monocromática, usou-se filtro amarelo, com $\lambda$ igual a $0,59 \mu$.

\section{Difração de raios $X$}

A difração de raios $\mathrm{X}$ foi aplicada, em suas diversas modalidades, para a identificação das inclusões e dos satélites do diamante, através de suas constantes reticulares. Êste método permitiu, igualmente, determinar a orientação das inclusões epitáxicas, em relação ao cristal hospedeiro, possibilitando, ainda, a caracterização dos geminados de diamante. Serão citados, a seguir, os processos empregados e os objetivos da sua aplicação.

\section{a. Método de Laue}

Os diagramas de Laue foram tomados na câmara de precessão, conservando-se $\mu$. igual a $0^{\circ}$ (sendo $\mu$. o ângulo de precessão), e utilizando-se o foco pontual do tubo de Mo sob $35 \mathrm{kV}$ e $20 \mathrm{~mA}$. A vantagem dêste procedimento reside no fato de poder-se trabalhar com pequenas distâncias entre o cristal e o filme, o que permite reduzir, para apenas alguns minutos, o tempo de exposição. Êste processo mostrou-se bastante eficiente na seleção de amostras interessantes, a serem submetidas a estudos posteriores, sendo também aplicado no exame de cristais geminados de diamante, quando os dados morfológicos foram insuficientes para o seu reconhecimento.

\section{b. Método do pó}

Os trabalhos de rotina, para a identificação de satélites e minerais associados, bem como de inclusões extraídas do hospedeiro, foram efetuadas pcr meio de diagramas de pó, obtidos com radiacão $\mathrm{Cu} \mathrm{K}_{\alpha}\left(\lambda=1,5418_{\AA}^{\circ}\right)$, em câmara tipo Buerger, modificada por Camargo e Svisero (1966), cujo diâmetro de $28 \mathrm{~mm}$ exige curtos períodos de exposição. Em casos em que se necessitava maior precisão nas medidas dos $\mathrm{d}_{\mathrm{hk} \ell}$, utilizou-se a câmara de $114,6 \mathrm{~mm}$ de diâmetro, tomando-se as precauções citadas por Azaroff e Buerger (1959), para a correção dos êrros sistemáticos.

$\mathrm{Na}$ identificação, comparou-se os $\mathrm{d}_{\mathrm{hk} \ell}$ observados $\mathrm{e}$ as intensidades relativas das reflexões correspondentes, estimadas visualmente, com os padrões catalogados pelo fichário de diagramas de pó (X ray Powder File ASTM, 1965).

\section{c. Método da precessão}

O método da precessão, divulgado por Buerger (1964), foi, dentre todos, o mais aplicado no presente estudo, pela sua eficiência e versatilidade, além de não requerer a destruição da amostra.

Como o método de Laue, a precessão se aplica a monocristais; porém, enquanto os lauegramas são projeções esféricas 
distorcidas (gnomônicas) e superpostas de níveis do retículo recíproco cristalino, os diagramas de precessão constituem a projeção retigráfica de sòmente um dêstes níveis e, conhecendo-se, a priori, a orientação do cristal com relação ao feixe incidente, a sua interpretação é imediata.

Para se conseguirem êstes diagramas, utiliza-se a câmara de precessão e, segundo a técnica tradicional, o estudo da rêde recíproca cristalina é efetuado tomando-se fotografias orientadas perpendicularmente aos eixos cristalográficos $\mathrm{X}, \mathrm{Y}$ e Z, obtendo-se, desta forma. ns diagramas dos níveis recíprocos $0 \mathrm{k} \ell$, h0 $\ell$ e hk0 (níveis recíprocos de ordem zero), sendo necessários, para as fotografias dos níveis superiores $(1 \mathrm{k} \ell, 2 \mathrm{k} \ell$, etc.), sucessivos ajustes na distância entre o cristal e o filme. As limitações inerentes ao método, que muitas vêzes impedem a fotografia dêsses níveis, e a impossibilidade da orientação do cristal segundo uma das direções convencionais, levaram a aplicar, no presente trabalho, a técnica da "varredura" (Camargo e Leite, 1967), que consiste em orientar-se o cristal, de modo que uma direção recíproca qualquer [uvw] * coincida com o eixo de rotação do dial da câmara. Nesta posição, é possível fotografarem-se todos os níveis recíprocos que contêm a direção [uvw] *, bastando, para isso, apenas girar o dial da câmara, na medida de um ângulo prèviamente calculado. Mesmo sem o auxílio de dados morfológicos, a técnica da "varredura" permite o estudo da rêde recíproca de cristais e, por esta razão, mostrouse muito eficiente no estudo das inclusões, no interior do diamante, quando é impraticável a orientação, segundo a morfologia, $\mathrm{O}$ cálculo do ângulo de giro do dial, necessário para a fotografia de um nível recíproco desejado, bem como o problema da orientação, foram tratados por meio de projeções estereográficas, em que se pode visualizar a relação de polaridade dos retículos cristalinos, direto e recíproco.
Antes da identificação sistemática das inclusões, organizou-se uma tabela das distâncias interplanares, presentes nos minerais incluídos em diamante: olivina, granada e cromita (Futergendler, 1958). Essas distâncias (Tabela 2) foram calculadas a partir das constantes cristalográficas dêsses minerais e, na relação dos $\mathrm{d}_{\mathrm{hk} \ell}$ teóricos, excluiram-se os correspondentes a reflexões sistemàticamente cxtintas, devido ao grupo espacial. Prepararam-se também, com antecedência, as projeções estereográficas dos minerais suspeitos, com o objetivo de interpretarem-se, com maior segurança, os diagramas de precessão obtidos.

A identificação das inclusões foi efetuada pela comparação dos $\mathrm{hk} \ell$ observados com os constantes na Tabela 2 , confrontando-se também as medidas angulares entre as direções recíprocas, determinadas nos diagramas de precessão, com os ângulos diedros dêsses minerais, obtidos nas projeções estereográficas, sôbre o diagrama de Wulff. Esta operação permite determinar-se a natureza do cristal incluído com apenas uma fotografia, de um nível zero qualquer.

$\mathrm{Na}$ prática, o estudo é realizado com o diamante, contendo a inclusão, inicialmente orientado ao acaso, na câmara de precessão. Utilizando-se radiação policromática de Mo e $\mu$ igual a $10^{\circ}$, obtêmse fotografias de orientação, que revelam, além das reflexões do diamante (muito intensas), as da inclusão (menores e mais fracas). Nestas fotografias, pode-se selecionar um nível recíproco de ordem zero da inclusão que, depois de orientado, pode ser fotografado sem distorções. Em nosso estudo, êstes diagramas foram tomados com $\mu=20^{\circ}$, utilizando-se o feixe pontual não filtrado do tubo de Mo.

A orientação das inclusões epitáxicas pode também ser determinada na câmara de Buerger. Desde que os diagramas de precessão constituem projeções não distorcidas de um nível do retículo recíproco cristalino, é possível, através delas, determinar a orientação do cristal 
Tabela 2

Distâncias interplanares de inclusões de diamantes (até $\mathrm{d}_{\mathrm{hk} \ell}=1,500 \stackrel{\AA}{\mathrm{A}}$ )

a. Olivina

$\mathrm{a}_{0}=4,76-4,82 \stackrel{\circ}{\AA}$

$\mathrm{b}_{0}=10,20-10,48 \stackrel{\AA}{\circ}$

$\mathrm{c}_{0}=5,99-6,10 \stackrel{\circ}{\AA}$

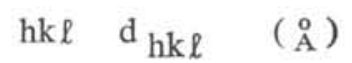

hk $\ell \quad \mathrm{d}_{\mathrm{hk} \ell} \quad(\stackrel{\circ}{\mathrm{A}})$

hk $\ell \quad d_{h k \ell}$

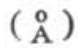

$\begin{array}{lll}020 & 5,10-5,24\end{array}$

$2112,161-2,192$

$2202,156-2,190$

$1412,105-2,154$

$123 \quad 1,732-1,764$

$060 \quad 1,700-1,747$

$241 \quad 1,671-1,703$

$1322,032-2,074$

$2212,029-2,060$

$230 \quad 1,950-1,984$

$0421,942-1,987$

$150 \quad 1,875-1,922$

$2021,863-1,891$

$0231,860-1,896$

$231 \quad 1,854-1,886$

$1031,841-1,874$

$2121,833-1,861$

$113 \quad 1,812-1,845$

$1421,798-1,853$

$151 \quad 1,789-1,805$

$2221,750-1,779$

$240 \quad 1,740-1,774$
$061 \quad 1,635-1,679$

$2321,634-1,663$

$1331,619-1,651$

$1601,601-1,642$

$1521,589-1,626$

$043 \quad 1,572-1,606$

$3101,568-1,588$

$250 \quad 1,549-1,582$

$161 \quad 1,547-1,586$

$301 \quad 1,534-1,553$

$311 \quad 1,516-1,537$

$3201,515-1,536$

$2131,513-1,537$
$2102,318-2,349$

$122 \quad 2,270-2,313$

$140 \quad 2,248-2,302$

b. Granada

\begin{tabular}{|c|c|c|c|c|c|c|c|c|}
\hline \multirow[b]{2}{*}{ hk $\ell$} & \multicolumn{5}{|c|}{$a_{0}=11,52-12,06 \stackrel{\circ}{\AA}$} & \multicolumn{3}{|c|}{$a_{0}=8,20-8,32 \AA$} \\
\hline & $\mathrm{d}_{\mathrm{hk} \ell}$ & $\left(\begin{array}{l}\circ \\
\AA\end{array}\right)$ & hk $\ell$ & $\mathrm{d}_{\mathrm{hk} \ell}$ & $(\AA)$ & hk $\ell$ & $\mathrm{d}_{\mathrm{hk} \ell}$ & $(\stackrel{\circ}{\AA})$ \\
\hline 211 & 4,70 & $-4,92$ & 433 & 1,976 & $-2,07$ & 111 & 4,73 & $-4,83$ \\
\hline 220 & 4,08 & $-4,27$ & 442 & 1,920 & $-2,01$ & 220 & 2,90 & $-2,96$ \\
\hline 222 & 3,33 & $-3,48$ & 611 & 1,869 & $-1,956$ & 311 & 2,47 & $-2,52$ \\
\hline 321 & 3,08 & $-3,22$ & 620 & 1,821 & $-1,907$ & 222 & 2,37 & $-2,41$ \\
\hline 400 & 2,88 & $-3,02$ & 541 & 1,778 & $-1,861$ & 400 & 2,05 & $-2,09$ \\
\hline 411 & 2,72 & $-2,84$ & 622 & 1,737 & $-1,818$ & 331 & 1,881 & $-1,918$ \\
\hline 420 & 2,58 & $-2,70$ & 631 & 1,699 & $-1,778$ & 422 & 1,674 & $-1,706$ \\
\hline 332 & 2,46 & $-2,57$ & 444 & 1,663 & $-1,741$ & 333 & 1,578 & $-1,609$ \\
\hline 422 & 2,35 & $-2,46$ & 543 & 1,629 & $-1,706$ & 511 & 1,578 & $-1,609$ \\
\hline 431 & 2,26 & $-2,37$ & 640 & 1,598 & $-1,672$ & & & \\
\hline & 2,10 & $-2,20$ & 721 & 1,568 & $-1,641$ & & & \\
\hline & 2,04 & $-2,13$ & 642 & 1,539 & $-1,612$ & & & \\
\hline
\end{tabular}

em estudo. Quando se fotografam diversos cristais simultâneamente - como é o caso de inclusões em diamantes - os diagramas obtidos podem apresentar a superposição dos níveis dos retículos recíprocos dos cristais, o que permite de- terminar a sua orientação mútua e, conseqüentemente, estabelecer qual ou quais os planos reticulares onde pode ocorrer o crescimento epitáxico.

A fim de se obterem diagramas de precessão suficientemente precisos, deve- 
se, primeiramente, orientar o diamante, de modo que sua direção [111] ou [110] coincida com o eixo de rotação do dial da câmara: esta orientação permite aplicar a técnica da "varredura" com a máxima eficácia. Obtemos, desta forma, diversas fotografias de precessão de níveis recíprocos de ordem zero do diamante, e, entre elas, selecionamos as que tam. bém apresentam níveis recíprocos de ordem zero da inclusão, o que sòmente ocorre se ambos os níveis são pràticamente coincidentes, dentro de um limite de precisão de $\pm 3^{\circ}$.

A coincidência de níveis do retículo recíproco pode ser interpretada como coincidência de zonas do retículo direto, pois ambos os retículos são polares e, transportando-se para a projeção estereográfica estas zonas coincidentes, podemos ràpidamente determinar os planos

$$
\begin{aligned}
\Gamma[\mathrm{uvw}] & =\mathrm{a}_{0}^{2} \cdot \mathrm{u}^{2}+\mathrm{b}_{0}^{2} \cdot \mathrm{v}^{2}+\mathrm{c}_{0}^{2} \cdot \mathrm{w}^{2} \\
& \pm 2 \mathrm{vwb}{ }_{0} \mathrm{c}_{0} \cos a \pm 2 \mathrm{uwa}{ }_{0} \mathrm{c}_{0} \cos \beta \pm 2 \mathrm{uva}{ }_{0} \mathrm{~b}_{0} \cos \%
\end{aligned}
$$

onde:

$\mathrm{a}_{0}, \mathrm{~b}_{0}, \mathrm{c}_{0} a, \beta \mathrm{e} \vee$ são as constantes da cela unitária e [uvw] os índices da direção considerada, inferiores a 3 . sistemas ortogonais): cristalográficos que permitem a epitaxia. Admitindo-se, segundo a maioria dos autores, que os planos de crescimento do diamante são paralelos à face do octaedro, sòmente êstes planos poderão servir de suporte à epitaxia e a operação se simplifica, resumindo-se na determinação dos planos cristalográficos da inclusão coincidentes com o plano (111) do diamante. Isto feito, pode-se comprovar a epitaxia, através da verificação da coincidência dos nós reticulares nestes planos, observando-se a equivalência dos períodos de translação - T [uvw] em duas direções [uvw] e o ângulo formado entre elas. Para maior rapidez de interpretação, foram preparadas, com antecedência, tabelas com as translações no diamante e das inclusões epitáxicas possíveis (Tabela 3), usando-se a expressão:

Os ângulos entre essas direções podem ser obtidos gràficamente, por meio de projeções estereogràficas e sôbre o diagrama de Wulff, ou, então determinados pela relação (válida sòmente para

$$
\cos [\mathrm{uvw}]:\left[u^{\prime} v^{\prime} w^{\prime}\right]=\frac{u^{\prime} \mathrm{a}_{0}^{2}+\mathrm{vv}^{\prime} \mathrm{b}_{0}^{2}+\mathrm{ww}^{\prime} \mathrm{c}_{0}^{2}}{\mathrm{~T}[\mathrm{uvw}] \cdot \mathrm{T}\left[\mathrm{u}^{\prime} \mathrm{v}^{\prime} w^{\prime}\right]}
$$

\section{Absorção ao infravermelho}

A determinação das propriedades espectrográficas do diamante, verificadas pelo seu comportamento em relação à absorção de raios infravermelhos, teve, como objetivo, classificá-los de acôrdo com o tipo (tipo Ia, Ib, IIa ou IIb), o que permitiu estimar a freqüência dêsses tipos nos diamantes provenientes do Triângulo. De outro lado, pôde'se ainda, comparar os espectros obtidos com outras propriedades estudadas: côr, morfologia, estruturas de superfície, presença de inclusões e defeitos de crescimento.

Normalmente, os aspectros de absorção de infravermelho de sólidos, são efe- tuados com amostras pulverizadas e confeccionando se pastilhas de $\mathrm{Kbr}$, como suporte. Com a finalidade de se conservarem as amostras para estudos futuros, não foi utilizada a técnica convencional, destrutiva, e os diagramas foram obtidos do material bruto, com um dispositivo especial para amostras microscópicas, adaptável ao aparêlho Perkin Elmer 421.

\section{Fluorescência}

O exame dos diamantes, sob a lâmpada de quartzo, foi realizado com o objetivo análogo ao do estudo espectrográfico de absorção ao infravermelho. Dêste modo, compararam'se a presença, a in- 
Tabela 3

Translações reticulares do diamante e inclusões (até u, v ou w $=3$ )

\begin{tabular}{|c|c|c|c|c|c|}
\hline \multicolumn{2}{|c|}{ a. Diamante } & \multicolumn{2}{|c|}{ b. Granada } & \multicolumn{2}{|c|}{ c. Cromita } \\
\hline \multicolumn{2}{|c|}{$\mathrm{a}_{0}=3,5667 \AA$} & \multicolumn{2}{|c|}{$a_{0}=11,60 \stackrel{\circ}{\AA}$} & \multicolumn{2}{|c|}{$\mathrm{a}_{0}=8,30 \AA$} \\
\hline [uvw] & $\mathrm{T}[\mathrm{uvw}]\left(\begin{array}{l}\mathrm{o} \\
\AA\end{array}\right)$ & [uvw] & $\mathrm{T}[\mathrm{uvw}]\left(\begin{array}{l}\mathrm{a} \\
\mathrm{A}\end{array}\right)$ & [uvw] & $\mathrm{T}[\mathrm{uvw}](\mathrm{\AA})$ \\
\hline 100 & 3,57 & 100 & 11,60 & 100 & 8,30 \\
\hline 110 & 5,04 & 110 & 16,40 & 110 & 11,74 \\
\hline 111 & 6,18 & 111 & 20,09 & 111 & 14,38 \\
\hline 210 & 7,97 & 210 & 25,94 & 210 & 18,59 \\
\hline 211 & 8,74 & 211 & 28,41 & 211 & 20,33 \\
\hline 221 & 10,69 & 221 & 34,80 & 221 & 24,90 \\
\hline 310 & 11,28 & 310 & 36,68 & 310 & 26,24 \\
\hline 311 & 11,83 & 311 & 38,48 & 311 & 27,53 \\
\hline 320 & 12,96 & 320 & 41,83 & 320 & 29,93 \\
\hline 321 & 13,34 & 321 & 43,41 & 321 & 31,06 \\
\hline 322 & 14,71 & 322 & 47,83 & 322 & 34,22 \\
\hline 331 & 15,55 & 331 & 50,56 & 331 & 36,18 \\
\hline 332 & 16,72 & 332 & 54,40 & 332 & 38,93 \\
\hline & & & - Olivina & & \\
\hline & $=4,76 \AA$ & $\mathrm{b}_{0}$ & $=10,20 \AA$ & $\mathrm{c}_{0}$ & $=5,99 \AA$ \\
\hline [uvw] & $\mathrm{T}[\mathrm{uvw}](\stackrel{\circ}{\mathrm{A}})$ & [uvw] & $\mathrm{T}[\mathrm{uvw}](\stackrel{\circ}{\AA})$ & [uvw] & $\mathrm{T}[\mathrm{uvw}](\stackrel{\circ}{\mathrm{A}})$ \\
\hline 100 & 4,76 & 311 & 18,54 & 123 & 27,60 \\
\hline 001 & 5,99 & 103 & 18,59 & 322 & 27,63 \\
\hline 101 & 7,65 & 302 & 18,64 & 223 & 28,82 \\
\hline 010 & 10,20 & 203 & 20,34 & 323 & 30,71 \\
\hline 201 & 11,25 & 013 & 20,67 & 130 & 30,97 \\
\hline 110 & 11,26 & 120 & 20,95 & 031 & 31,18 \\
\hline 011 & 11,83 & 113 & 21,20 & 131 & 31,54 \\
\hline 111 & 12,75 & 312 & 21,25 & 230 & 32,05 \\
\hline 102 & 12,89 & 021 & 21,26 & 231 & 32,59 \\
\hline 210 & 13,95 & 213 & 22,74 & 132 & 33,20 \\
\hline 211 & 15,18 & 221 & 23,30 & 232 & 34,21 \\
\hline 301 & 15,49 & 122 & 24,13 & 331 & 34,30 \\
\hline 012 & 15,73 & 320 & 24,90 & 032 & 34,35 \\
\hline 112 & 16,44 & 313 & 25,11 & 133 & 35,80 \\
\hline 310 & 17,55 & 321 & 25,61 & 233 & 35,83 \\
\hline 212 & 18,12 & 023 & 27,19 & 332 & 36,73 \\
\hline
\end{tabular}

tensidade e a côr da luminescência, com as propriedades já acima citadas. Neste estudo, utilizou-se como fonte de luz ultravioleta, o aparêlho Mineralight, com $\lambda$ igual a $3.660 \stackrel{\AA}{\circ}$.

\section{Métodos Químicos}

As análises químicas, por meios especiais, não foram aplicadas ao presente estudo, com exceção de sòmente uma, realizada com a microssonda de Castaing (electron micro-probe), a fim de se determinar a composição de inclusões negras e placóides, comuns em diamante. Nos trabalhos de rotina, limitou-se apenas aos ensaios, por via sêca ou úmida, recomendados nos guias de mineralogia determinativa(Leinz e Souza Campos, 1968), para a identificação dos satélites e minerais associados. 


\section{GENERALIDADES}

Um grande número de trabalhos científicos, versando sôbre as propriedades, composição, síntese, aplicação, ocorrência e origem do diamante, são constantemente publicados, e a razão dêste interêsse reside no fato de tratar-se de substancia ímpar, incomparável a qualquer um de seus sucedâneos, nesta ou naquela aplicação. A sua raridade, as sociada à durabilidade e às propriedades ópticas, The conferem valor gemológico inestimável, tendo, ainda, larga aplicação industrial, como material de corte e abrasivo.

Os primeiros mineralogistas e cristalógrafos se ocuparam da morfologia estranha do diamante, não observada em outro mineral e, a descoberta dos depósitos diamantíferos primários, nos fins do século passado, fêz com que a atenção dos estudiosos se voltasse para o problema da origem, datando dessa época, também, os primeiros ensaios de síntese. As bases teóricas para a produção artificial seriam, no entanto, estabelecidas sòmente anos mais tarde, e o início da produção em escala industrial do produto sintético, só foi possível recentemente.

Um outro problema que muito preocupou os pesquisadores antigos, referiase ao seu caráter holoédrico ou hemiédrico, o que constitui até hoje problema aberto, mesmo depois de conhecida a sua estrutura cristalina, determinada em 1913. De outro lado, grande progresso no estudo de suas propriedades, sentiuse após a publicação do trabalho de Robertson, Fox e Martin (1934), quando os diamantes foram classificados em dois tipos distintos. Nas décadas de 40 e 50, físicos da escola hindu e da escola inglêsa tentaram interpretar a existência dêsses tipos, através de estruturas teó ricas, deduzidas com base em suas propriedades espectrográficas. Sòmente em 1959, porém, conseguiu-se relacionar os diversos tipos observados e as respectivas propriedades características, com a presença de impurezas, principalmente do nitrogênio (Kaiser e Bond, 1959).

\section{SOBBRE O DIAMANTE}

O trabalho dos cristalógrafos e geólogos atuais é, não só a obtenção de diamantes sintéticos com propriedades prefixadas e a baixo custo, como o estabelecimento definitivo das condições de origem, para que novas jazidas sejam localizadas.

\section{Cristalografia}

Sob o ponto-de vista morfológico, os cristais de diamante raramente externam a relativa simplicidade de sua estrutura. A natureza de suas formas peculiares, apresentando faces arredondadas e arestas curvas, será ainda, objeto de muitos estudos futuros. As formas cristalográficas tidas como seguramente observadas, segundo Goldschmidt (1916): $\langle 100\rangle$, $\langle 110\rangle,\langle 111\rangle,\langle 211\rangle,\langle 322\rangle,\langle 331\rangle$, $\langle 552\rangle,\langle 332\rangle$, eram consideradas hemiédricas, em virtude de sua simetria in ferior, revelada por estrias sôbre as faces dos cristais (Fersman e Goldschmidt, 1911). Após a determinação da estrutura do diamante, quando a simetria holoédrica foi verificada nos diagramas de difração de raios $\mathrm{X}$, poucos autores (Beckenkamp, 1926) continuaram a admitir a hemiedria .

No que diz respeito à natureza das faces arredondadas, Fersman e Goldschmidt (1911) foram talvez os primeiros a suspeitar da dissolução natural, como responsável pelo seu desenvolvimento, no que foram severamente criticados por Williams (1932), que admitiu serem resultantes de crescimento (faces vicinais). Atualmente, os autores se dividem, apoiando esta ou aquela interpretação existindo, ainda, os que consideram a origem híbrida, ou seja, crescimento e dissolução.

O diamante apresenta estrutura característica, bem conhecida (Bragg e Bragg, 1913), que pode ser interpretada como a interpretação de dois retículos cúbicos, $\mathrm{A}$ e $\mathrm{B}$, centrados nas faces, estando, a origem de A em $(0,0,0)$ e de B em $(1 / 4,1 / 4,1 / 4)$.

Os tetraedros dos retículos A e B acham-se opostamente orientados, decor- 
rendo, disto, a simetria holoédrica do conjunto (grupo espacial $\mathrm{Fd} 3 \mathrm{~m}$ ). A simetria pontual da cela unitária é, no entanto, hemiédrica. O parâmetro unitário, a obtido de cristais individuais, é variável: $3,55970 \pm 20 \mathrm{kx}$ (Bijvoet, 1951).

\section{Composição Química}

O mais puro dos diamantes ainda pode apresentar $0,001 \%$ de impurezas, e as pedras de boa qualidade contêm, em média, 99,9\% de carbono (Seal, 1968). Entre as impurezas, a mais importante é o nitrogênio, que ocorre em teores de até $0,25 \%$ (Kaiser e Bond, 1959), e a sua influência, sôbre as propriedades físicas, é tal modo importante, que constitui a base da moderna classificação do diamante, segundo os tipos $\mathrm{Ia}, \mathrm{Ib}$, IIa e $\mathrm{IIb}$.

Desde 1934, admite-se a existência de dois tipos fundamentais (tipos I e II), com diferente comportamento físico (Robertson, Fox e Martin), o que se expli$\mathrm{ca}$, atualmente, pela presença de nitrogênio nos diamantes do tipo I. A princípio, julgou-se que esta impureza se encontrasse na forma de átomos substancionais isolados e, assim sendo, tais diamantes deveriam apresentar ressonância eletro-paramagnética (E.P.R.), devida à diferença de valência do carbono e nitrogênio. Verificou-se, no entanto (Smith et al., 1959), que os diamantes, mesmo contendo altas concentrações de nitrogênio, não apresentavam essa propriedade, concluindo-se, então (Elliot, 1960), que os átomos de nitrogênio deveriam estar segregados, concentrando-se em plaquetas, posteriormente verificadas, através da microscopia eletrônica (Evans e Phaal, 1962). A presença de difração anômala de raios $\mathrm{X}$ por diamantes dêste tipo já havia sido anteriormente observada por Wooster e Hoerni (1955) e Caticha-Ellis e Cochran (1958). Alguns cristais de diamante, porém, podem apresentar nitrogênio em centros paramagnéticos, o que indica que a impureza está sob a forma substitucional. Dêste modo, os dia- mantes do tipo I foram classificados em Ia, com plaquetas de nitrogênio, e Ib, mais raros, com nitrogênio substitucional.

De maneira análoga, os diamantes do tipo II foram subdivididos (Custers, 1952) em dois grupos: tipo Ila, teòricamente puros, e tipo IIb, cujas impurezas (A1 ou talvez $\mathrm{B}$ ou $\mathrm{Be}$ ), lhe conferem características semicondutoras.

Além do nitrogênio, muitas impurezas podem ocorrer como elementos menores (Chesley, 1942; Raal, 1957): Si, Al, Ca e $\mathrm{Mg}$; mais raramente, $\mathrm{Fe}$, $\mathrm{Ti}$ e $\mathrm{Cu}$, podendo ainda existir traços de $\mathrm{Ag}, \mathrm{Cr}, \mathrm{Na}$, $\mathrm{Ba}, \mathrm{Sr}$ e $\mathrm{Pb}$. Estas impurezas, aparentemente, não se relacionam com o tipo do diamante, podendo ocorrer nos diamantes do tipo II como nos do tipo I (Bunting e Van Valkenburg, 1958).

\section{Propriedades Físicas}

Considerando-se o diamante estruturalmente perfeito e constituído apenas por átomos de carbono, fortemente unidos entre si, por ligações direcionais covalentes, podem-se prever algumas de suas propriedades físicas teóricas. Os diamantes naturais e sintéticos, no entanto, apresentam comportamento físico anômalo, explicado como conseqüência de defeitos estruturais (vacâncias, átomos intersticiais, deslocamentos, etc.), muitos dêles provocados pela presença de impurezas. Artificialmente, é possível introduzirem-se defeitos análogos, no retículo cristalino do diamante, através do bombordeamento com nêutrons, eléctrons, raios $\mathrm{X}$ ou raios gama, que pode acarretar o deslocamento dos átomos de carbono, produzindo-se, assim, vacâncias e átomos intersticiais.

Entre as até agora observadas, as propriedades ópticas são as mais intensamente afetadas por êstes defeitos estruturais, admitindo-se ser o nitrogênio o principal responsável pelas anomalias verificadas nos espectros ópticos de absorção ou emissão. Desta forma, os diamantes do tipo Ia e Ib absorvem as radiações ultravioletas de comprimento de onda inferiores a $3.000^{\circ} \AA(4 \mathrm{eV})$, en- 
quanto os do tipo IIa e IIb são transparentes, até o limite inferior de 2.300 $(5,4 \mathrm{eV})$. Do mesmo modo, os do tipo Ia e Ib apresentam um sistema de bandas de absorção à radiação infravermelha, no intervalo de 7,5 a $9,0 \mu$, o que não se observa nos diamantes do tipo IIa e IIb. Podem-se distinguir os tipos Ia e $\mathrm{Ib}$, pela intensidade relativa dessas bandas. Diamantes de todos os tipos absorvem na região de 3 a $6 \mu$; no entanto, sòmente os do tipo $\mathrm{IIb}$ apresentam picos de absorção anômalos dentro dêsse intervalo. Além disso, êstes diamantes são comumente azulados (Premier Blues), mostrando, ainda, picos de absorção muito pronunciados, na região do visível.

A fluorescência - azul, verde ou amarela - é observada, geralmente, nos diamantes do tipo I, quando submetidos à radiação ultravioleta, sendo freqüente o padrão geométrico da distribuição desta fluorescência, o que é explicado pelo zoneamento de camadas com diferente natureza, durante o crescimento. Os diamantes do tipo IIb são normalmente fosforescentes.

Outra propriedade óptica importante, conhecida desde o século passado, é a birrefringência anômala, atualmente admitida como fenômeno de piezobirrefringência (Pointdexter, 1955). O diamante torna-se birrefringente, uniaxial ou biaxial negativo, quando submetido a pressões dirigidas, dependendo o caráter óptico, da direção na qual a fôrça é aplicada. $\mathrm{O}$ diamante com inclusões frequentemente exibe esta anomalia e a tensão interna, responsável pela birrefringência, é devida aos diferentes coeficientes de dilatação do diamante e do cristal incluído. Êste fenômeno indica, seguramente, que a inclusão é contemporânea ou preformada. Muitos diamantes, ou mesmo a totalidade, como admite Tolansky (1966), apresentam birrefringência anômala causada por outros fatôres, que não as inclusões. Este comportamento anômalo levou Friedel (1932) a admitir uma fase paramórfica do diamante $(\beta)$, estável acima de $1885^{\circ} \mathrm{C}$ (à pressão ambiente), quando se verifica uma alteração nos padrões de birre- fringência. Segundo Friedel, as tensões internas seriam originadas pela transformação paramórfica de beta para alfa (forma estável à temperatura e pressão ambientes), com alteração de volume. Tolansky (1966) admite o intercrescimento de diversos tipos de diamante (I e II), como a causa das tensões internas.

Assim como o comportamento óptico, as propriedades mecânicas do diamante estão intimamente relacionadas com a presença de nitrogênio. Os diamantes estruturalmente menos perfeitos (tipo I) apresentam dureza maior, pois os seus defeitos cristalinos aumentam a energia interna do retículo, como acontece nas ligas metálicas. A clivagem, neste caso, é mais difícil, e a sua superfície não apresenta a regularidade observada no tipo II. Ambos os tipos apresentam variações, na dureza de abrasão (Kraus e Slawson, 1939), sendo menor nas direções paralelas aos eixos cristalográficos $\mathrm{X}, \mathrm{Y}$ e Z . Dêste modo, a face (100) apresenta durezas maiores ao longo das diagonais, enquanto que nos planos (110), isto se verifica sòmente ao longo da diagonal menor. $\mathrm{Na}$ face de octaedro não existem direções paralelas a $\mathrm{X}, \mathrm{Y}$ e $\mathrm{Z}$ e, neste plano, as direções de menor resistencia à abrasão (do centro da face para as arestas), apresentam dureza maior que as observadas ao longo da diagonal da face do cubo ou do rombododecaedro. A variação desta propriedade, nas três direções, não pode ser representada por uma superfície contínua, como no caso da indicatriz óptica (Denning, 1953).

Com relação ao pêso específico, variável entre 3,51477 e $3,52554 \mathrm{~g} / \mathrm{cm}^{3}$, a $25^{\circ} \mathrm{C}$ (Mikolajevsky et al., 1964), os diamantes do tipo I são mais densos, o que indica presença de impurezas com pêso atômico maior do que o do carbono, confirmando, portanto, a ocorrência de nitrogênio, nestes cristais .

\section{Variedades}

A literatura mineralógica cita, ao lado do diamante comum, a ocorrência de diversas formas imperfeitas, consti- 
tuídas por agregados policristalinos. Comumente, são denominados borte, carbonado, etc., mas a terminologia, ainda obscura e utilizada arbitràriamente, é aplicada também às variedades de diamante inadequadas à lapidação.

Williams (1932) cita, como variedades mais comuns, o borte, a stewartita, a framesita, a bala e o granizo. No Brasil, empregamos o têrmo carbonado, para designar uma variedade com as mesmas características do borte, descrito por Williams: agregado policristalino, de granulação variável, entre fânero e criptocristalina; coloração escura; de cinza a preta; alto teor de impurezas ( $10 \%$ em média) e baixa densidade (aproximadamente 3,48). O mesmo têrmo é, entre nós, aplicado para o monocristal de diamante negro, originado, possìvelmente, pela grafitização parcial (Friedel, 1932). As outras variedades (framesita, stewartita e bala), apresentam, em linhas gerais, as mesmas propriedades do borte ou carbonado. A framesita dêles se distingue apenas pela granulação mais fina, e pelo brilho, tendendo ao vítreo, em algumas regiões. A stewartita é a variedade de borte magnético, o que se deve às inclusões de magnetita. A bala é o borte de tom cinza-metálico, com forma arredondada. O caráter fibrorradiado, admitido para explicar a forma esférica desta última variedade, não foi observado em secções polidas (Fischer, 1961).

A alta dureza de abrasão, apresentada por estas variedades, é consequiência da descontinuidade dos planos de clivagem, entre os diversos grânulos que constituem o agregado.

O granizo, como o diamante negro, parece não apresentar natureza policristalina e suas características são totalmente diversas das do borte ou carbonado. Distingue se do diamante comum, por ser opaco e apresentar níveis de crescimento com coloração cinza de tons diferentes. A sua morfologia, dureza e densidade, são comparáveis às do diamante puro, apresentando, no entanto, cêrca de $2 \%$ de seu pêso, no resíduo de combustão.

As variedades policristalinas de diamante podem ser consideradas como geminados múltiplos e complexos, de $\mathrm{di}^{-}$ fícil interpretação, como admite Slawson (1950).

\section{Ocorrência}

O diamante é explorado, desde a antiguidade, em depósitos aluvionares e, sòmente nos fins do século passado, se teve notícia de sua ocorrência primária, em Kimberley (África do Sul). Nestes depósitos, o diamante ocorre em condutos vulcânicos ultrabásicos $(40 \%$ de $\mathrm{SiO}_{2}$ ), denominados kimberlitos, constituídos de rochas peridotíticas, tufáceas ou brechiformes, parcialmente serpentinizadas, contendo olivina, apatita, perowskita, ilmenita, cromita, enstatita, granada e diopsídio.

Atualmente, admitese que tais rochas sejam a matriz primária do diamante ou, pelo menos, o meio de transporte dos cristais já formados, para regiões mais superficiais da crosta.

Ocorrências de diamante, ligadas a magmatismo menos básico, são descritas no dolerito de Oakey Creek (Austrália) e no augita-andesito de Holsdam (África do Sul).

Após a descoberta de Kimberley, tentou-se localizar as possíveis matrizes, nas regiões onde se encontravam diamantes aluvionares. No Brasil, essas buscas foram infrutíferas, sendo, no entanto, bem sucedidas na Rússia, onde se encontraram diamantes em chaminés, do tipo kimberlítico (Urais e Yakutia), e na India, onde os depósitos aluvionares parecem ligar-se a condutos vulcânicos ultramáficos, em Panna (Mathur, 1962). Chaminés de kimberlito diamantífero são ainda encontradas nos E.U.A. (Piky County, Arkansas). Em várias localidades da África (Serra Leoa, Tanganica e Congo), admite-se que o diamante se relacione com rochas kimberlíticas.

São também citadas ocorrências de cristais diminutos (100 ̊ $)$, em meteo- 
ritos (condritos), em concentrações de até $0,3 \%$ (Urey et al., 1957).

\section{Sintese}

A produção artificial do diamante, desde há muito, interessou aventureiros de todo o mundo, mas os primeiros ensaios realizados com algum rigor científico, e cujos resultados são hoje postos em dúvida, foram empreendidos por Hanay (1880) e Moissan (1894), submetendo compostos de carbono a altas pressões e altas temperaturas. As primeiras tentativas bem sucedidas, no entanto, foram obtidas em 1955, pela $\mathrm{Ge}$ neral Eletric (E.U.A.), ASEA (Suécia) e De Beers (África do Sul), após o perfeito estabelecimento do diagrama de equilíbrio grafita-diamante (Rossini et al., 1952).

Este diagrama, modificado por Berman (1964), nos mostra que o diamante é estável, à temperatura ambiente $\left(298^{\circ} \mathrm{K}\right)$, acima de $16,1 \mathrm{katm}$, exigindo pressões muito maiores, a temperaturas mais elevadas. A transformação direta grafita-diamante é, porém, possí- vel sòmente a pressões ou temperaturas elevadíssimas $\left(300 \mathrm{katm}\right.$ ou $4.000^{\circ} \mathrm{C}$ ), razão pela qual se utilizam catalisadores metálicos, no processo de síntese. O mecanismo de formação seria, neste caso, um pouco mais complexo: a grafita dissolve-se no metal fundido, sob a forma de carbono atômico e o diamante começa a cristalizar-se quando as condições de pressão e temperatura se situam na sua região de estabilidade, formando-se grafita abaixo da curva de equilibrio (Simon, 1968b).

Os limites do domínio de formação do diamante, são, dêste modo, constituídos pela própria curva de estabilidade grafita-diamante e a linha de fusão do metal ( $\mathrm{Fe}, \mathrm{Ni}$, Nicrômio, Inconel, Ni-Ge, etc.), ou do eutético, se fôr o caso.

Recentemente, tentaram-se outros meios de síntese, fora da região de estabilidade do diamante, a baixas pressões e a baixas temperaturas. O mecanismo de desenvolvimento, nestes processos, poderia ser explicado através da cinética de formação (Simon, 1968b) .

\section{MORFOLOGIA}

A morfologia do diamante do Triângulo Mineiro tem sido estudada sòmente em gemas de porte descomunal, provenientes dos garimpos de Coromandel e Estrêla do Sul. No entanto, os resultados dêsses estudos não podem ser considerados representativos, devido ao caráter verdadeiramente anômalo de tais amostras, tôdas elas ultrapassando 100 quilates métricos, em pêso.

A primeira destas pedras, "Estrêla do Sul" (254 quilates métricos), foi encontrada em 1853, no Rio Bagagem e parecia tratar-se de um diamante naturalmente clivado, apresentando ainda faces curvas de hexatetraedro ou rombododecaedro, o que se pode deduzir através de desenhos atribuídos a Duffrénoy (Reis, 1959).

Em 1938, Barbosa descreveu o "Minas Gerais” (172,5 quilates métricos), concluindo ser o octaedro a forma dominante, o que se deve, talvez, à clivagem natural, pois a fase (111), em diamantes muito desenvolvidos, raramente deve ocorrer.

Leinz (1939), estudou o "Presidente Vargas" (770 quilates métricos), o sexto, na relação mundial dos grandes diamantes, tendo encontrado, além dos planos de clivagem, faces curvas e irregulares do rombododecaedro.

O diamante "Darcy Vargas" (460 quilates métricos), segundo Leonardos e Saldanha (1939), apresentava planos de octaedro e faces menos desenvolvidas de cubo, rombododecaedro e tritetraedro. As faces (111) foram caracterizadas, pelos autores, por meio de figuras de contôrno triangular indefinido; entretanto, pela fotomicrografia publicada no trabalho, pode-se considerar que 
tais planos devem ser do tipo hexatetraédrico, fortemente abaulados. O mesmo deve ocorrer com o diamante "Coromandel" (400,65 quilates métricos) (Saldanha, 1941), onde o hábito octaédrico é resultante da associação de cinco planos de clivagem e duas faces (111) naturais, porém recurvadas. No mesmo trabalho, o autor ainda ressalta a frequência de diamantes perfeitamente octaédricos que ocorrem em Piứ (extremo SE do Triângulo), não esclarecendo, contudo, o tamanho das amostras.

Fato interessante é a proveniência comum dêstes diamantes, todos êles encontrados no Rio Santo Antônio das Minas Vermelhas, afluente do Paranaíba (Município de Coromandel, MG).

Outros grandes diamantes, "Governador Valadares" (Saldanha, 1942); "Independência" e outros (Reis, 1959), apresentavam as mesmas características gerais dos diamantes acima descritos: ausência de faces planas naturais, ocorrendo, em seu lugar, formas indefinidas, com arestas e faces curvas e irregulares, o que torna a orientação morfológica possível sòmente pelos planos de clivagem, quase sempre presentes.

As amostras de menor porte podem apresentar, entretanto, a predominância de um hábito definido, o que permite classificá-las, sob o ponto-de-vista morfológico, e, daí, estimar a freqüência dos diversos hábitos, entre os diamantes do Triângulo Mineiro. Tal estudo, aparentemente simples, é dificultado pela ocorrência de faces curvas, comuns em diamante, que impossibilitam o perfeito reconhecimento das formas cristalográficas presentes. Muitos autores a elas se referem, através dos seus índices, mas a insegurança dêste procedimento pode ser verificada pela total ineficiência dos dados goniométricos, necessários para a sua determinação. Por êste motivo, será evitada, na descrição das formas observadas, a nota segundo o índice, com exceção das formas $\langle 111\rangle,\langle 110\rangle$ e $\langle 100\rangle$, que parecem as únicas originadas por fenômenos de crescimento cristalino, podendo, neste caso, apresentar faces planas. A terminologia adotada na descrição das demais formas cristalográficas, refere-se ao hábito do cristal, o que pode não concordar com a nomenclatura convencional, utilizada para designar as formas simples, com relação à classe de simetria à qual pertencem . Serão empregados, dêste modo, os têrmos octaedro e trioctaedro, correspondentes a formas holoédricas, ao lado de hexatetraedro, que se refere a uma forma hemiédrica.

A classificação adotada, com a finalidade de sistematizar o estudo das formas presentes, considera, de início, quatro tipos característicos: formas simples, formas combinadas, formas irregulares e geminados, fàcilmente identificáveis nos diamantes do Triângulo. Os hábitos cristalinos observados e que serão descritos a seguir, podem incluir-se dentro de um dêstes tipos. Em alguns casos, no entanto, esta classificação pode assumir caráter subjetivo, em virtude da ocorrência de hábitos intermediários.

\section{Formas simples}

Entre os diamantes que apresentam formas simples, pode-se distinguir, à primeira vista a predominância do hábito octaédrico ou rombododecaédrico, sendo raramente verificado o desenvolvimento do hábito cúbico. As características e variações de cada um, serão tratadas separadamente.

\section{a. Hábito octaédrico}

Considerando que o desenvolvimento do diamante se efetua pelo empilhamento de planos (111), como é admitido pela maioria dos autores, o octaedro seria a forma de equilíbrio, durante o crescimento do cristal. No entanto, cristais octaédricos perfeitos, apresentando vértices e arestas bem delineados, não foram encontrados entre as amostras estudadas, excluindo-se, no caso, os sólidos de clivagem. A face (111) ocorre freqüentemente e a sua superfície, plana e regular não é observada em nenhuma ourta forma; porém, está sempre associada a faces arredondadas de rombo- 
dodecaedro ou hexatetraedro, que substituem os vértices e arestas do octaedro.

É também comum, os diamantes do Triângulo, o cristal de hábito octaédrico, com arestas e vértices reentrantes, originado pelo crescimento de dois ou mais indivíduos paralelos. Vários autores interpretam estas formas como resultantes de geminação, segundo (100) ou [100] (geminado de Mohs), o que é possível admitir, considerando a simetria hemiédrica do cristal. O desenvolvimento do hábito tetraédrico de dois indivíduos, encontrado num só exemplar (Figura 4 a), sugere, a princípio, esta interpretação. Freqüentemente, observam-se, em cristais dêste tipo, a substituição dos vértices e arestas por faces curvas, resultando numa forma semelhante à descrita por Valarelli (1963).

Os tipos intermediários, nos diamantes de hábito octaédrico, situam-se entre o octaedro quase perfeito, com arestas e vértices pouco arredondados, e as formas combinadas de octaedro e rombododecaedro (Figura 4 i). Pode-se considerar ainda o meio-têrmo entre o agregado de vários indivíduos paralelos (Figura $4 \mathrm{~b}$ ) e a forma combinada, apresentando faces de cubo, octaedro e rombododecaedro (Figura $4 \mathrm{~h}$ ). Quando ocorre o arredondamento das arestas e vértices nestes cristais, pode-se notar o início do desenvolvimento do hábito trioctaédrico (Figura 4d).

Além dos diamantes octaédricos equidimensionais, é possível encontrarem-se octaedros com hábito tabular, segundo (111). Observaram'se, ainda, cristais alongados na direção [110]; parecem. porém, sólidos de clivagem.

\section{b. Hábito rombododecaédrico}

A forma rombododecaédrica é a mais comum entre as observadas, em decorrência do grande número de variantes que pode apresentar, não havendo, contudo, limite nítido entre elas. Pode-se, no entanto, distinguir a predominância de três formas, tôdas elas mostrando faces arredondadas e arestas curvas: o rombododecaedro pròpriamente dito, o hexatetraedro e o trioctaedro.
Os diamantes perfeitamente rombododecaédricos são raros, e as faces (110), nestes cristais, podem-se apresentar extremamente lisas, como se fôssem artificialmente polidas, notando-se, em alguns casos, ligeiro sulco, ao longo de sua diagonal maior. Em outros, êstes planos são estriados, nesta mesma direção, o que lhes confere hábito semelhante ao trioctaedro (Figura 4d). Nestas duas variantes, pode-se verificar, e é comum, o desenvolvimento de arestas sinuosas, poucos salientes e irregulares, na direção da diagonal menor das faces (110). Quando tais arestas se mostram mais perfeitas e pronunciadas, a forma resultante exibe hábito nìtidamente hexatetraédrico (Figura 4c ), que, em alguns casos, faz lembrar o cubo piramidado, pelo igual desenvolvimento nas direções [111], o que se observa nas variedades opacas de diamante.

Não se verificam, nas formas trioctaédricas, a presença das arestas do octaedro, que aqui são substituídas por faces do tipo (110), fortemente recurvadas (Figura $4 \mathrm{~d}$ ). E possível, também, nestas amostras, observarem-se as arestas sinuosas e os sulcos já citados na face de rombododecaedro e, na medida em que êstes elementos melhor se definem, o conjunto pode tomar o aspecto do hexaoctaedro.

Entre os diamantes rombododecaédricos característicos, é comum a ocorrência de amostras alongadas numa das direções [111], decorrendo, disto, o hábito prismático dêsses cristais. Nos diamantes hexatetraédricos já se observa, com freqüência, o hábito tabular, segundo (111) (Figura $4 \mathrm{e}$ ), que também pode ser encontrado em cristais do tipo trioctaédrico (Figura 4f). O maior desenvolvimento de duas faces paralelas, neste último tipo, pode originar uma forma achatada, segundo um dos eixos de simetria binária (Figura $4 \mathrm{~g}$ ) .

\section{c) Hábito cúbico}

Os cristais cúbicos ocorrem sòmente em variedades translúcidas ou opacas de diamante, e suas faces, apesar de planas, 


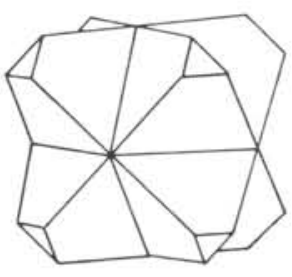

a

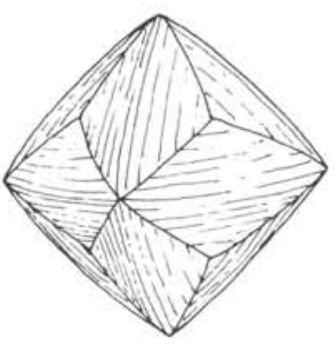

d

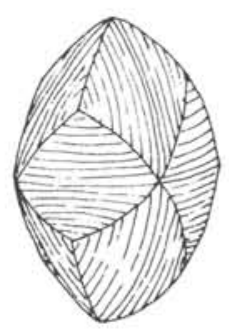

g

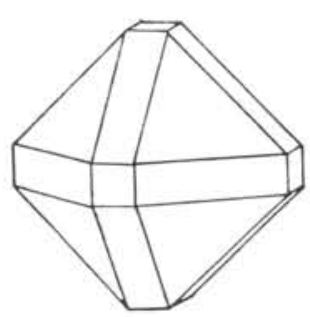

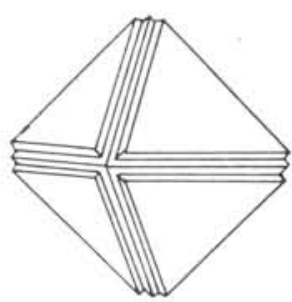

b

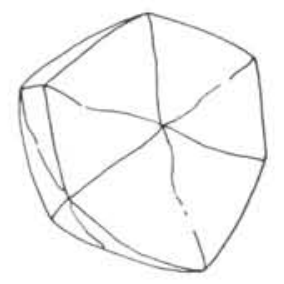

e

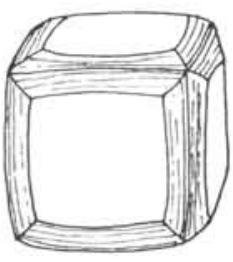

r

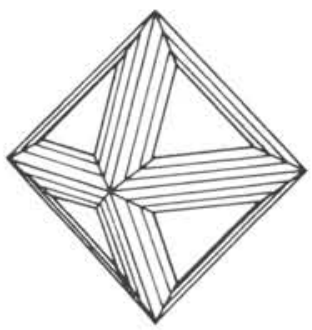

k

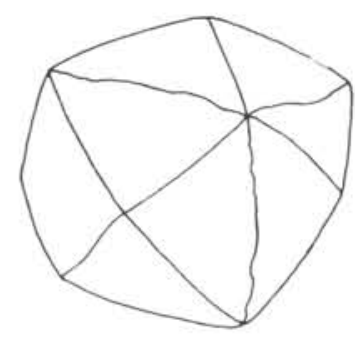

L

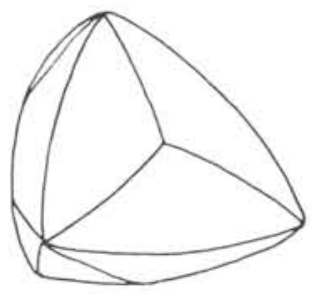

f

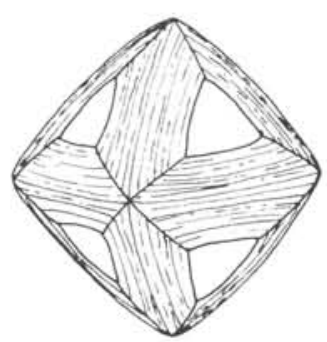

i

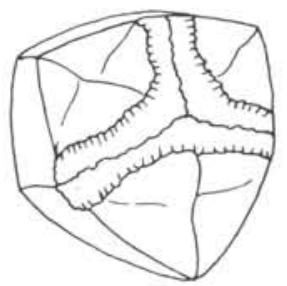

L

Figura 4 - a. Geminado de Mohs; b. Agregado paralelo de vários octaedros; c. Hexatetraedro com faces arredondadas; d. Trioctaedro com faces arredondadas; e. Hexatetraedro tabular; f. Trioctaedro tabular; g. Trioctaedro achatado segundo um $\mathrm{E}_{2} ; \mathrm{h}$. Cubo com arestas arredondadas (combinado de cubo e rombododecaedro); i. Combinado de octaedro e rombododecaedro; j. Combinado $111-110-$ 100 ; k. Combinado 111 - hh; 1. Geminado hexatetraédrico, pseudo-múltiplo. 
apresentam-se corroídas irregularmente. Este hábito é raramente observado e, em vista disto, as características aqui descritas podem não ser representativas. Entretanto, nas poucas amostras cúbicas encontradas, nota-se, como no octaedro, a substituição das arestas e vértices por faces arredondadas e irregulares de rombododecaedro ou hexateraedro (Figura $4 \mathrm{~h})$. O hábito cúbico, nestes cristais, é equidimensional, verificando-se, em apenas um indivíduo, ligeiro achatamento segundo (111), o que lhe conferia hábito romboédrico.

\section{Formas combinadas}

Há cristais de diamante em que se pode observar a combinação de mais de um dos hábitos citados, sendo mais freqüentes os que apresentam faces planas de octaedro. Estes cristais mostram, além da forma $\langle 111\rangle$, faces arredondadas de formas rombododecaédricas ( $\mathrm{Fi}$ gura 4 i).

Nos cristais cúbicos, quando os vértices e arestas se tornam mais arredondados, verifica-se, também, o desenvolvimento do hábito rombododecaédrico (Figura $4 \mathrm{~h}$ ).

Podem-se, no entanto, considerar como formas combinadas autênticas, apenas as que apresentam a associação de $\langle 110\rangle,\langle 111\rangle$, e $\langle 100\rangle$, ou ainda, \{111\} e $\langle 100\rangle$. São raramente encontradas, e talvez sejam as únicas combinações originadas por crescimento cristalino. Neste casos, as faces (110) e (100) apresentam-se planas, verificando-se a presença de estrias paralelas e bem definidas, ao longo da diagonal maior da face de rombododecaedro. A forma combinada de $\langle 111\rangle-\langle 110\rangle$ - $\langle 100\rangle$ (Figura $4 \mathrm{j}$ ) ocorre geralmente em cristais translúcidos, denominados "cascudos", pelos garimpeiros, e a associação de $\langle 111\rangle$ e $\langle 100\rangle$ foi observada em apenas um exemplar incolor de extrema limpidez.

São encontrados, também, cristais apresentando a combinação de $\langle 111\rangle$ $\mathrm{e}\langle\mathrm{hh} \ell\rangle$, com faces planas e estriadas. As medidas goniométricas, no entanto, são inseguras para a perfeita caracterização desta última forma (Figura $4 \mathrm{k}$ ).

\section{Formas irregulares}

Muitos diamantes, principalmente os maiores, não apresentam hábito definido, desenvolvendo-se ou achatados, ou alongados, ou irregularmente, sendo difícil a sua orientação. Apesar da grande semelhança com os cristais de hábito rombododecaédrico, a sua irregularidade morfológica não permite classificá. -los em nenhum dos tipos precedentes. Nestas amostras, não se observam faces planas e os cristais são limitados por superfícies curvas do tipo rombododecaédrico. Por vêzes, êstes planos mostram-se tão recurvados, que não se podem notar as arestas formadas por êles.

Algumas destas formas são vulgarmente designadas por "lascas" ou "lascados". Podem-se incluir entre os diamantes do tipo irregular, os sólidos de clivagem, em que a morfologia original é inacessível, e é o caso de muitos dos grandes diamantes citados na literatura.

\section{Geminados}

Pode-se considerar os geminados como resultantes de acidentes, durante o crescimento cristalino (Simon, 1968a), ocorrendo isto em virtude da pequena diferença da energia de adesão, na configuração normal ou na de geminação. Há autores (Buerger, 1945) que admitem, no limite entre dois individuos geminados, uma estrutura polimórfica possível. Tal acontece com a blenda ( $\mathrm{ZnS}$ cúbico), onde dois cristais geminados segundo [111] têm, no contacto, a estrutura da wurtzita ( $\mathrm{ZnS}$ hexagonal).

No diamante, o empilhamento se faz em camadas de tetraedros, paralelas a (111), e a geminação é verificada quando êstes tetraedros se unem ao substrato, a $60^{\circ}$ da posição normal. Segundo Slawson (1950), quando o acoplamento se dá na posição intermediária, a $30^{\circ}$, o tetraedro gira para a posição de empilhamento normal, e a neutralidade deve ocorrer sòmente a 10 ou $15^{\circ}$ da posição de geminação, pois a energia su- 
perficial é influenciada pelo arranjo das camadas inferiores. Abaixo dêste limite, o tetraedro gira para a posição de $60^{\circ}$, podendo originar um segundo indivíduo cristalino. Sendo êste fenômeno freqüente, na cristalização do diamante, pode-se admitir que, em escala submicroscópica ou mesmo microscópica, todos os diamantes devem apresentar áreas ou regiões geminadas (Slawson, 1950). A camada entre dois indivíduos, neste caso, apresenta simetria hexagonal, e a existência dessa fase polimórfica do diamante, com estrutura semelhante à da wurtzita (Ergun e Alexander, 1967), vem apoiar a suposição de Buerger (1945).

Adotando-se a interpretação geométrica, os geminados dêste tipo, definidos através de seus elementos de geminação, têm (111) como plano de composição original e plano de geminação, sendo [111] o eixo de geminação. Em tôdas as amostras observadas, verificou-se obediência a esta condição (lei do espinélio), notando'se sòmente a variação da morfologia externa dos geminados, cuja descrição poderá ser mais um elemento a caracterizar o diamante do Triângulo Mineiro.

Em geral, sob o ponto-de-vista morfológico, os geminados de diamante tem forma indefinida, podendo ser fàcilmente confundidos com os cristais simples, de forma irregular. Dêles distinguem-se, no entanto, pela presença de "suturas" ou "costuras", observadas no contacto dos dois indivíduos. Nos casos de difícil caracterização morfológica, os geminados podem ser reconhecidos, através de diagramas de difração de raios X (método de Laue ou precessão), que revelam a simetria senária, causada pela superposição de dois cristais mùtuamente girados $60^{\circ}$.

Entre os geminados com formas definidas, os mais freqüentes exibem hábito tabular, designados comumente por "chapéus-de-frade", e constituídos de dois indivíduos octaédricos achatados, segundo o plano de geminação. Nas amostras dêste tipo, pode-se notar a substituição dos vértices e arestas dos octaedros, por faces curvas, como ocorre na forma simples. Num dêstes geminados, do tipo hexatetraédrico, o maior desenvolvimento de um dos cristais resultou numa forma singular, que, de início, sugere a geminação múltipla (Figura 41).

A geminação cruzada é relativamente comum nos cristais cúbicos, verificando-se, num dos exemplares, acentuada diferença de coloração dos dois indivíduos. Esste tipo de geminação pode ser interpretado, geomètricamente, de maneira análoga à anterior. Do ponto-devista estrutural, porém, deve-se admitir a existência de um plano de composição original diferente de (111).

Os geminados múltiplos podem apresentar formas arredondadas e irregulares, mas obedecem às condições verificadas na geminação simples. Encontraram-se, entre as amostras estudadas, agrupamentos dêste tipo, constituídos por três indivíduos, não se observando o paralelismo entre os elementos de geminação. O geminado múltiplo descrito por Palache (1932), também presente nos diamantes do Triângulo, pode ser considerado como dois geminados simples, parcialmente cruzados.

Por meio de difração de raios $\mathrm{X}$, verificou-se, ainda, um geminado com forma externa perfeitamente octaédrica, limitada por faces planas e irregularmente corroídas, não se determinando, contudo, o caráter simples ou múltiplo da geminação .

\section{Frequência das formas cristalográficas}

O estudo da frequiência das diversas formas e hábitos, presentes nos diamantes do Triângulo Mineiro, deveria restringir-se a áreas diamantíferas isoladas. Os resultados, neste caso, seriam mais úteis, podendo-se verificar as variações morfológicas, nos diferentes depósitos. A incerteza da proveniência exata de muitas amostras impediu tal procedimento, e os resultados do presente estudo podem ser considerados representa- 
tivos, respeitando-se as características da amostragem efetuada. O tamanho dos cristais, por exemplo, deve ser um dos primeiros fatôres a ser observado, verificando'se, de imediato, a predominância de indivíduos geminados ou de formas irregulares, nas amostras de pêso superior a 0,5 quilates métricos. De outro lado, em cristais pouco desenvolvidos (inferiores a 0,10 quilates), pode-se notar a ocorrência freqüente de rombododecaedros equidimensionais, com faces lisas e arredondadas.

$\mathrm{Na}$ Tabela 4 é mostrada a freqüência percentual, segundo as formas e hábitos presentes. Foram, aqui, separadas as formas combinadas em transicionais, com faces curvas associadas à forma $\langle 111\rangle$, e formas combinadas autênticas, que apresentam a combinação das for$\operatorname{mas}\langle 111\rangle,\langle 110\rangle$ e $\langle 100\rangle$ ou $\langle 111\rangle$ e $\langle 100\rangle$, pois parecem originadas por processos diversos.

Nota-se, entre os diamantes do Triângulo, a predominância da forma simples rombododecaédrica, seguindo-lhe, em freqüência, os geminados de contôrno irregular.

\section{Origem das formas cristalográficas}

A morfologia cristalina é, atualmente, explicada, em base estrutural, pela teoria dos vetores $\mathrm{PBC}$, de Hartman e Perdok (1955), que admite, no cristal, a existência de cadeias de ligações periódicas (Periodic Bond Chain ou PBC), paralelas aos principais eixos de zona a formadas pelas sucessivas ligações entre as partículas vizinhas, mais fortemente unidas entre si. As faces paralelas aos PBC serão, portanto, as mais desenvolvidas e, nos cristais onde aparecem mais de um dêstes vetores, pode-se classificálas em três tipos, de diferentes expressões morfológicas: faces $\mathrm{F}$ (flat: plana), paralelas a pelo menos dois $\mathrm{PBC}$ e, conseqüentemente, as mais prováveis superfícies de equilíbrio; faces S (stepped: escalonada), paralelas a um vetor $\mathrm{PBC}$ e de ocorrência possível; e faces $K$ (kinked: reticulada), não paralelas a nenhum $\mathrm{PBC}$, o que torna improvável o seu desenvolvimento. As variações morfológicas observadas em muitos casos, são explicadas pela influência de impurezas, que se depositam

Tabela 4

Freqüência percentual de formas e hábitos

\begin{tabular}{|c|c|c|c|}
\hline Formas & $\begin{array}{l}\text { Freqüência } \\
\text { em \% }\end{array}$ & Hábito & $\begin{array}{c}\text { Freqüência } \\
\text { em } \%\end{array}$ \\
\hline \multirow{3}{*}{ Simples } & \multirow{3}{*}{45} & Octaédrico & 35 \\
\hline & & Cúbico & 2 \\
\hline & & Rombododecaédrico & 63 \\
\hline \multirow{2}{*}{ Combinadas } & \multirow{2}{*}{10} & Combinado Transicional & 78 \\
\hline & & Combinado Autêntico & 22 \\
\hline Irregulares & 12 & -- & -- \\
\hline \multirow{4}{*}{ Geminados } & \multirow{4}{*}{33} & Tabular & 33 \\
\hline & & Cúbico cruzado & 4 \\
\hline & & Irregular & 58 \\
\hline & & Múltiplo & 5 \\
\hline
\end{tabular}


simultâneamente e em níveis epitáxicos, alterando as direções dos PBC.

No diamante, as ligações covalentes entre os átomos de carbono, se efetuam, inicialmente, na direção [111], mas, a sua repetição periódica, resulta num vetor $\mathrm{PBC}$ paralelo a [110]. A única forma do tipo $\mathrm{F}$, possível, neste caso, seria o octaedro, seguindo-lhe, em ordem decrescente de importância morfológica, as formas S: $\langle 110\rangle,\langle 100\rangle,\langle 311\rangle$ e \{331\}. A predominância do hábito rombododecaédrico sôbre o cúbico é admitida pela maior velocidade de cristalização, ao longo de [100] (Hartman, 1953).

Seguindo esta interpretação e considerando, ainda, as condições particulares sob as quais o diamante se desenvolve, que limitam a interferência de impurezas, a única forma de equilíbrio admissível seria o octaedro. Esta conclusão pode ser fàcilmente atestada pela grande improbabilidade da mudança no mecanismo de crescimento, quando êste se verifica de maneira simples, como no diamante. Dêste modo, as formas tipo K ou S e de ocorrência comum, seriam improváveis como resultado de crescimento cristalino.

Constitui, ainda, flagrante anomalia, a freqüência da forma rombododecaédrica, nunca observada como forma de crescimento. Além disso, são raramente encontradas, entre os diamantes artificiais, ocorrendo sòmente quando há suspeita de dissolução, durante a síntese
(Bovenkerk, 1961; Bezrukow et al., 1966). A presença da face (110) plana, em algumas formas combinadas, po. de ser interpretada como resultante de faces vicinais, do tipo (111), e não como plano de crescimento.

A forma de equilíbrio cúbica foi observada aplenas em diamante sintéticos, obtidos sob condições de pressão e tem. peratura mínimas (Bovenkerk, 1961), e deve resultar do efeito de impurezas. A freqüência dêste hábito, em variedades opacas e translúcidas, de diamantes do Triângulo, além da presença de camadas com diferentes tonalidades, paralelas a (100), observadas num dêstes exemplares (Prancha Ia), sugere que êste tipo de crescimento também se processe naturalmente. $\mathrm{O}$ aparente paradoxo, entre o hábito hexatetraédrico da amostra e o mecanismo de crescimento, dificilmente poderia ser explicado pelo desenvolvimento cristalino normal.

Estas evidências, somadas aos resultados das observações sôbre figuras e estruturas de superfícies (tratados em capítulo à parte), indicam que as formas anômalas devem originar-se de processos de dissolução.

Este fenômeno é resultante da combustão parcial do diamante, em ambiente oxidante e a temperaturas provàvelmente elevadas. No laboratório, podem-se reproduzir condições análogas e pode-se provocar fàcilmente a corrosão dêstes cristais, com $\mathrm{KNO}_{3}$, ao redor de $500^{\circ} \mathrm{C}$. Como a dissolução, neste caso,

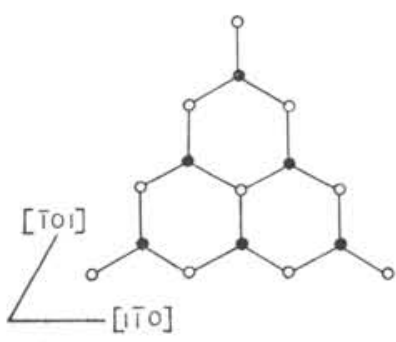

a

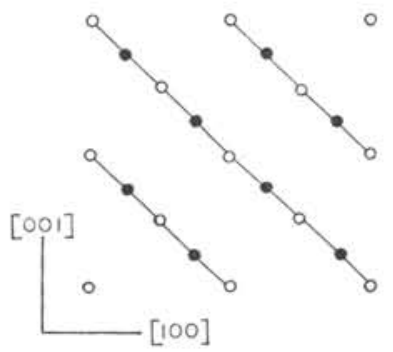

b

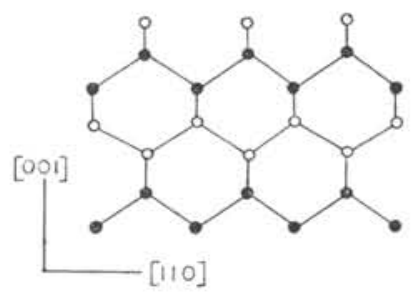

C

Figura 5 - Configuraçâo estável de (111) (a); (100) (b) e (110) (c). 
é muito rápida, as formas obtidas são irregulares, mas, em condições especiais, a forma de dissolução pode assemelhar-se às formas de crescimento, constituindo isto um meio de determinação da simetria cristalina (Buerger, 1956).

Outros agentes oxidantes, ainda citados, na corrosão do diamante, são o $\mathrm{CO}_{-i}$, a $1350^{\circ} \mathrm{C}$ (Evans e Phaal, 1962), ơu mesmo o $\mathrm{O}_{2}$, a baixas pressões (Omar e Kenawi, 1957). Em diamantes artificiais, a corrosão se efetua quando a pressão não é mantida, em altas temperaturas, e a passagem abrupta da dissolução ao crescimento torna freqüente a alternância dêstes dois processos, durante a síntese.

Admitindo-se a dissolução como o inverso do crescimento, podem-se também determinar as formas de equilíbrio possíveis, com base estrutural, e aplicando-se o método de Stranski-Kaishev (Simon, 1968 a), que leva em conta o trabalho de separação das partículas do edifício cristalino.

$\mathrm{Na}$ configuração estável da face de octaedro (Figura $5 \mathrm{a}$ ), pode-se notar que cada átomo, pertencente aos vetores $\mathrm{PBC}$, se liga a três outros do nível subjacente; e, para que a dissolução se verifique, é necessário que se rompam estas três ligações. A superfície de equilíbrio do cubo (Figura $5 \mathrm{~b}$ ) mostra que os átomos estão agora ligados a apenas dois outros, da camada imediatamente inferior, e, na face (110) (Figura 5 c ), cada um dos elementos dos vetores $\mathrm{PBC}$ se une a sòmente uma partícula do substrato. Disto pode-se con- cluir que as velocidades de dissolução devem variar, conforme a direção considerada, sendo maior ao longo de [110] e mais lenta em [111], decorrendo, como forma de equilíbrio, o rombododecaedro. Nesta forma, os principais eixos de zona correspondem às direções [111] $\mathrm{e}$ as faces desenvolvem-se perpendicularmente a [110].

A variação morfológica, observada nas formas de dissolução, poderia resultar das diferentes concentrações do solvente (Buerger, 1956), e também da forma inicial, da qual deriva.

Entre os hábitos, descritos em diamantes do Triângulo Mineiro, podem-se considerar como originados por crescimento cristalino, o octaedro, o cubo, e a forma combinada de $\langle 111\rangle$, $\langle 110\rangle$ e $\langle 100\rangle$. A dissolução dêstes cristais originaria as formas simples com faces curvas, desenvolvendo-se, primeiramente as formas combinadas transicionais; em seguida, o hexatetraedro ou o trioctaedro, dependendo do hábito inicial; e, num estágio final, o rombododecaedro (Figura 6).

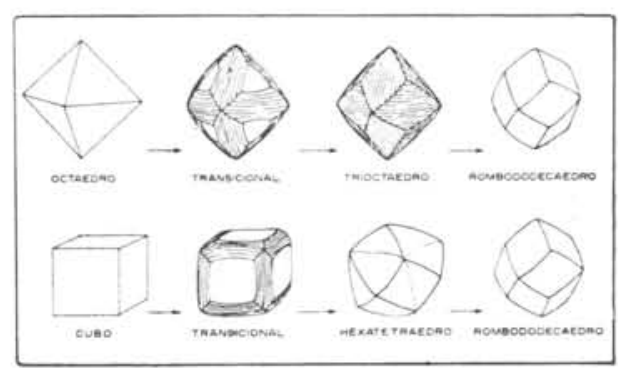

Figura 6 - Evolução da morfologia do diamante, explicada por meio da dissolução natural.

\section{FIGURAS E ESTRUTURAS DE SUPERFICIE}

A observação das marcas naturais que ocorrem na superfície do diamante, constitui meio seguro para a orientação do cristal, podendo também fornecer informações úteis sôbre o processo de desenvolvimento das formas cristalográficas, ou do seu mecanismo de crescimento. O grande número de publicações que trata do assunto, reflete a importância dêste tipo de estudo para o perfeito esclarecimento das condições da gênese do diamante: as marcas de superfície revelam o último estágio da evolução do cristal.

Algumas destas figuras originam se de processos diversos, como os moldes e "crateras", deixados por inclusões. Porém, a maioria das marcas de superfície mostra, nitidamente, o efeito da dissolução, existindo, ainda, algumas cuja 
origem é duvidosa, não se podendo provar se resultam de crescimento ou de corrosão. No entanto, nos cristais onde elas aparecem, notam-se, também, figuras provocadas por dissolução (Patel e Agarwal, 1965), o que leva a concluir que sòmente as feições macroscópicas de crescimento devam ocorrer na superfície de diamantes naturais. Outro fato interessante e que comprova esta afirmação, é a presença, em diamantes sintéticos, de espirais de crescimento, na face do cubo (Tolansky e Sunagawa, 1959) e do octaedro (Patel e Ramachandran, 1968), não encontradas em diamantes naturais.

Muitas das marcas superficiais do diamante são visíveis à vista desarmada, havendo casos, no entanto, em que sòmente se tornam perceptíveis com grande ampliação. Quando isto ocorre, tais figuras podem distribuir-se regularmente sôbre a superfície do cristal, revelando estruturas muitas vêzes macroscópicas e intimamente ligadas ao crescimento cristalino.

Considerando que as figuras e estruturas de superfície como típicas, em cristais da mesma procedência (Seal, 1962), pode-se avaliar a sua importância, como elemento de caracterização do diamante do Triângulo Mineiro.

\section{Faces de octaedro}

Nos planos (111), freqüientemente se observam depressões de contôrno triangular, denominadas trígonos, com fundo plano (Prancha Ib) ou escalonado, que, muitas vêzes, se desenvolvem como pirâmides negativas (Prancha I c ). A profundidade e o tamanho destas figuras são variáveis, mas o ângulo formado entre os planos das pirâmides e a face do octraedro é mais ou menos constante, variando de $0^{\circ} 40^{\prime}$ a $2^{\circ} 40^{\prime}$, dados êstes obtidos de figuras interferométricas. Êstes valôres indicam que tais faces não constituem planos reticulares com índices millerianos simples, e, portanto, devem ser instáveis, como forma de crescimento.
Algumas vêzes, os trígonos de fundo plano apresentam contôrno hexagonal, o que se observa também nas figuras de fundo piramidado (Prancha Id). Em trígonos dêste tipo, porém pouco desenvolvidos, pode-se notar o contôrno hexagonal perfeito que, em alguns casos, mostra duas fases na evolução (Prancha Ie ).

Comumente, os trígonos orientam-se opostamente, com relação ao contôrno triangular da face do octaedro, mas podem-se também encontrar figuras concordantes, e esta aparente anomalia faz perdurar, até hoje, as controvérsias sôbre a sua origem. As tentativas para obter artificialmente estas figuras, por meio da corrosão do diamante em $\mathrm{KNO}_{3}$ fundido a $500^{\circ} \mathrm{C}$, revelaram trígonos concordantemente orientados, nas faces (111), o que levou Williams (1932), Halperin (1956) e Tolansky (1960) a admitir o crescimento como responsável pelas figuras em oposição. Há autores, contudo, que as interpretam como efeito de agentes corrosivos, não importando a sua orientação. No entanto, parecem inacessíveis, as provas seguras para apoiar-se esta ou aquela suposição.

Considerando-se que o germe de crescimento bidimensional estável, na face (111), apresenta contôrno triangular, concordante com as arestas do octaedro (Simon, 1968 a), a nucleação em três pontos diferentes desta face, poderá originar cavidades triangulares em oposição. A cristalização rápida, por outro lado, formará, inicialmente, cristais esqueléticos (Bovenkerk, 1961), e o crescimento ulterior poderá delimitar cavidades, agora concordantes com as arestas do octaedro. Esta última suposição é, contudo, pouco provável, devido à configuração instável das camadas de crescimento (Simon, 1968 a). Na dissolução, o mesmo deve verificarse: quando a corrosão se processa lentamente, a forma estável da cavidade estará em oposição a (111); no entanto, quando a dissolução é violenta, como a realizada por meios artificiais, as figuras poderão orientar-se concordantemente . 


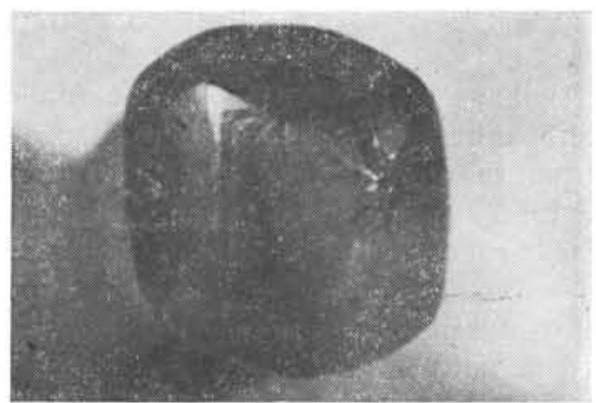

a

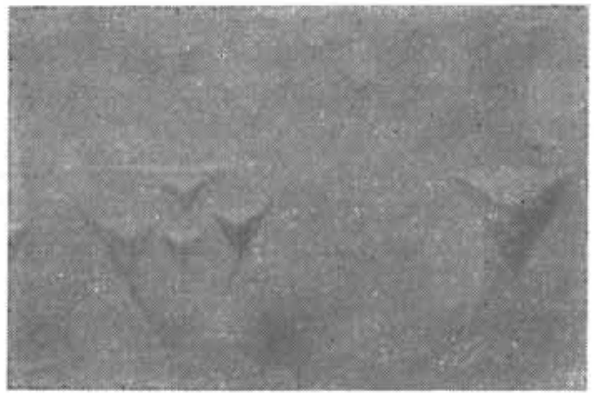

C

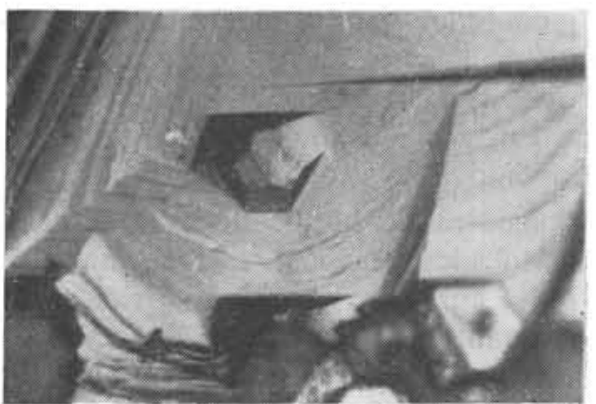

e

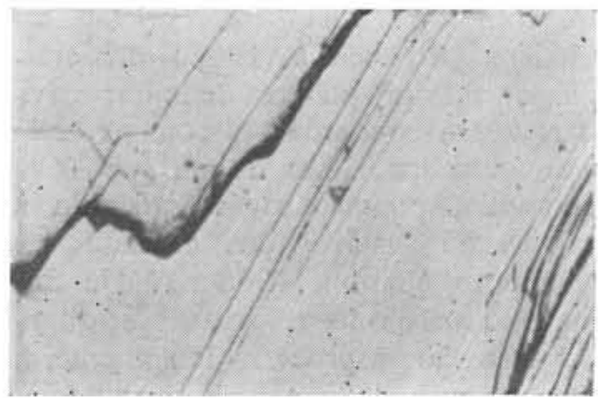

g

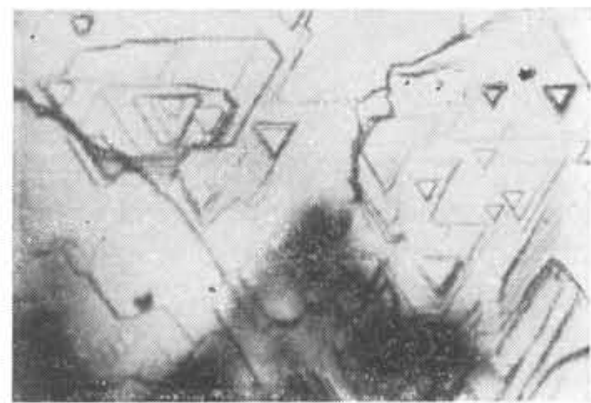

b

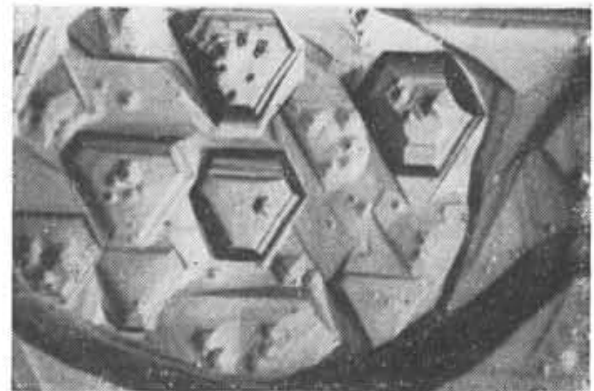

d

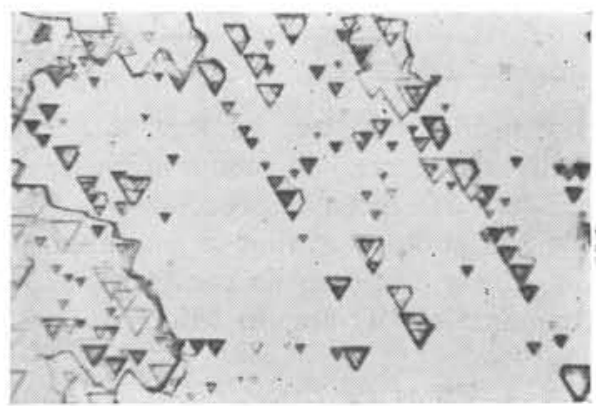

f

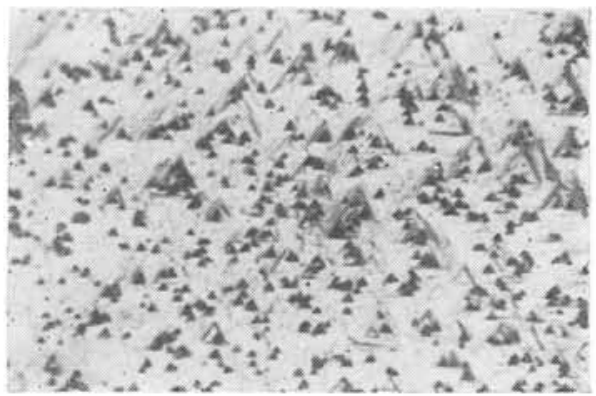

h

Prancha I - a. Níveis de crescimento paralelos a (100) em cristal hexatetraédrico (x4); b. Trígonos com fundo plano (x 75); c. Trigonos com fundo piramidado (x 75); d. "Trígono" com contôrno hexagonal $(x$ 130): e "Trigono" hexagonal mostrando duas fases na evolução $(x$ 130): $f$. Trigonos alinhados ( $\mathrm{x} 130) ; \mathrm{g}$. Trigonos em planos de clivagem $(\mathrm{x} 100) ; \mathrm{h}$. Trígonos concordantes, pouco desenvolvidos (x 130). 


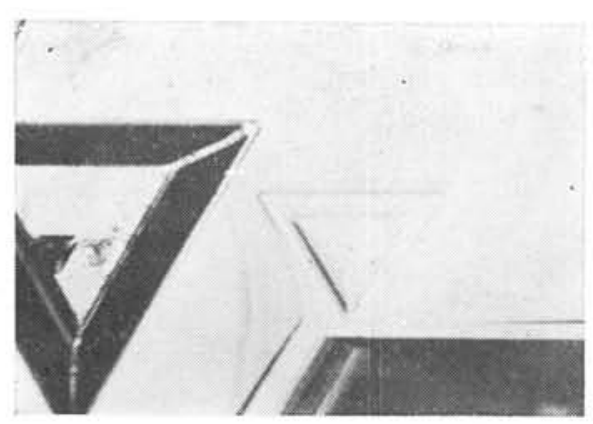

a

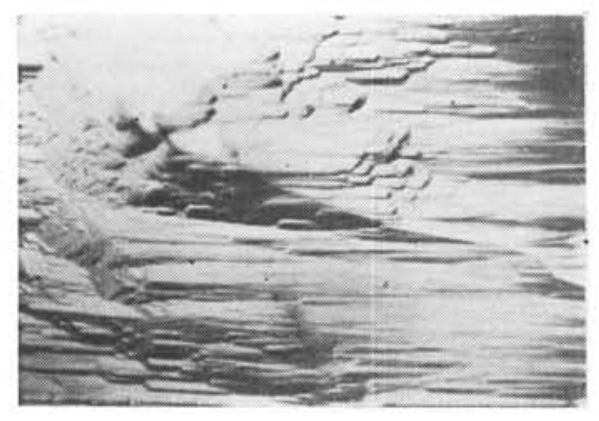

C

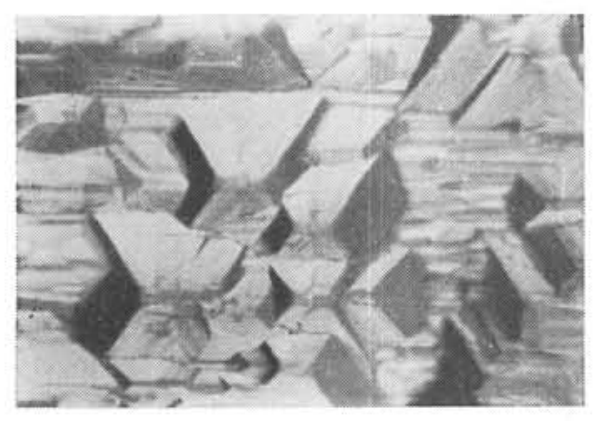

e

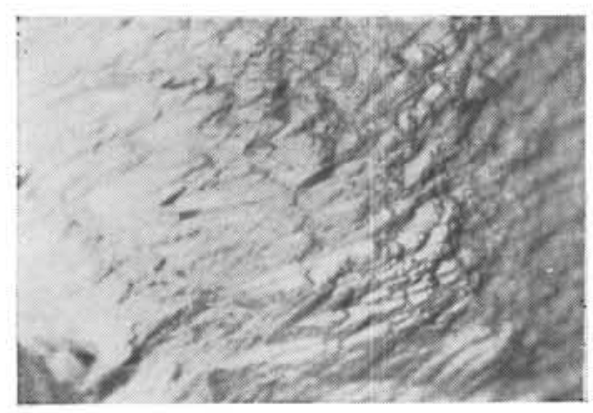

f

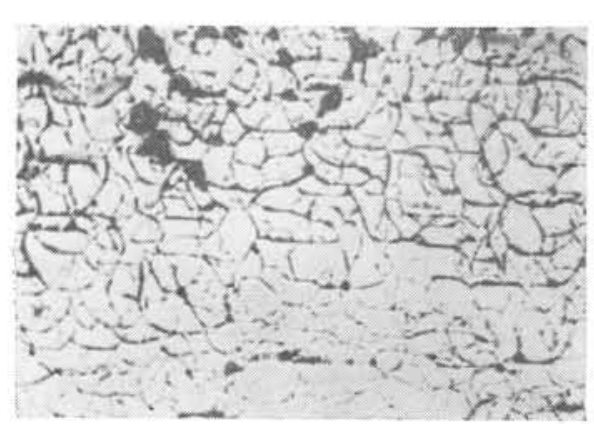

b

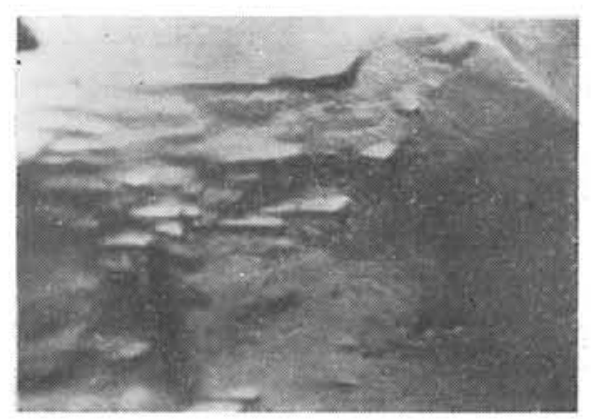

d

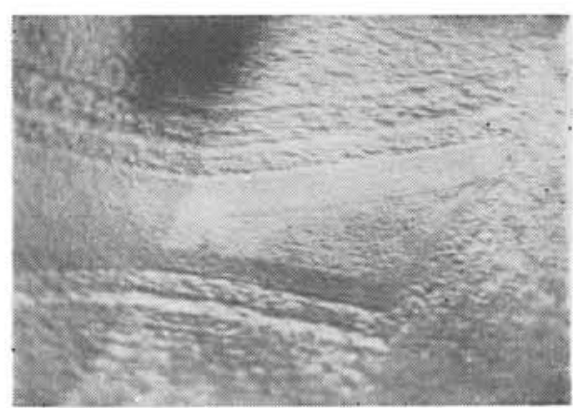

e

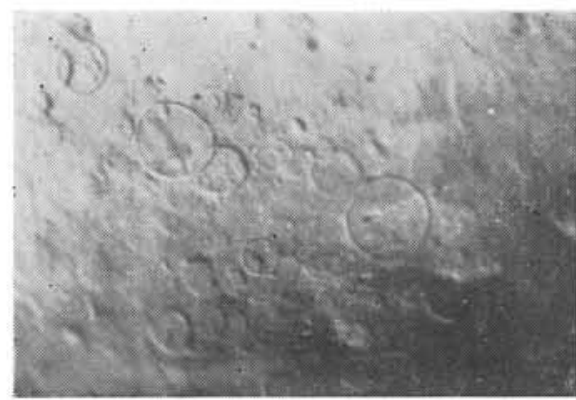

g

Prancha II - a. Trígonos concordantes e em oposição (x 130); b. Figuras de impacto em (111) (x75); c. Figuras alongacias em $(110)(x$ 100); d. Elevaçōes de contorno octaédrico em (110) ( $x$ 50); e.

Elevaçổes de contôrno geométrico definido em (110) (x130); f. Estrutura zonada em (110) (x75): $g$. figuras anômalas em (110) $(x$ 100); h. Microdiscos em (110) (x 100). 


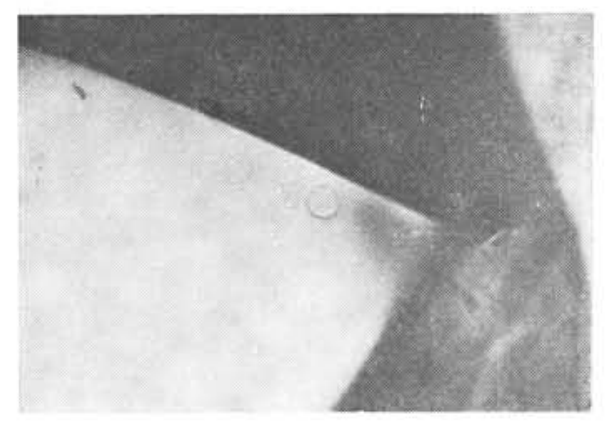

a

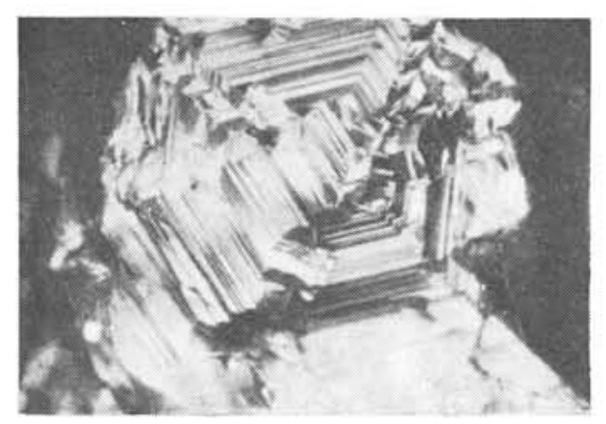

C

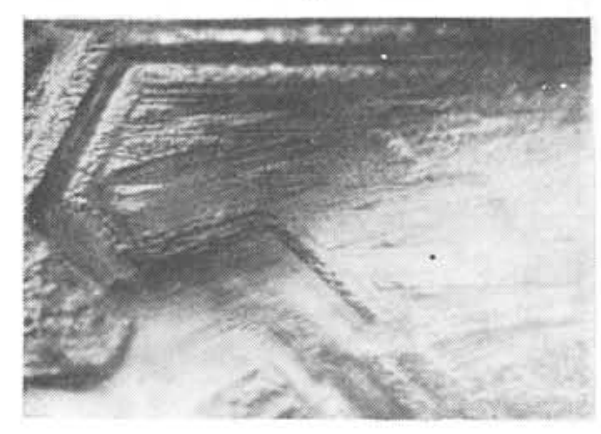

e

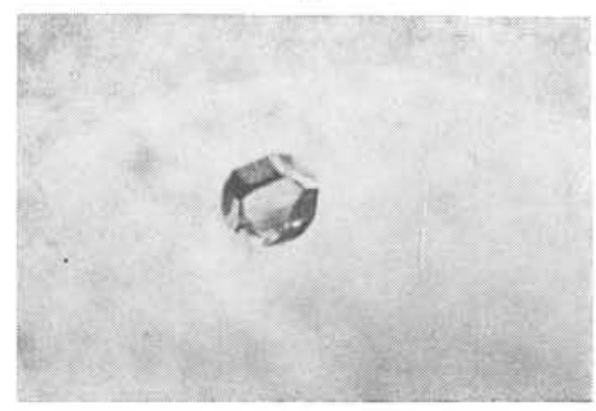

g

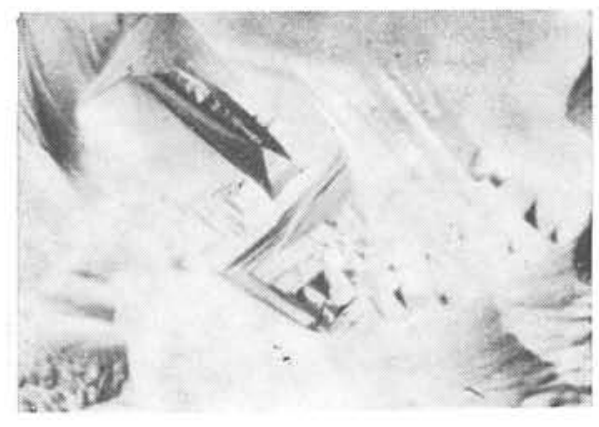

b
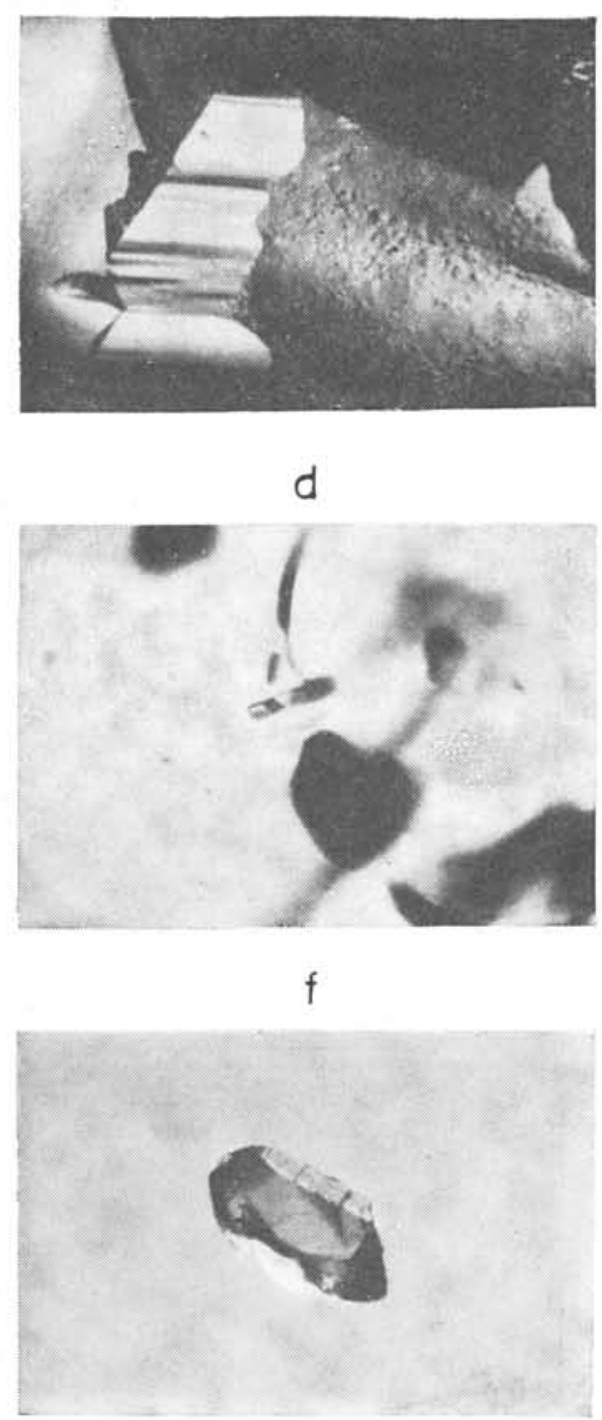

h

Prancha III - a. Disco circular em (110) (x 75); b. Figuras em (100) (x 120); c. "Suturas" em geminado múltiplo $\left(\begin{array}{ll}x & 25\end{array}\right)$; d. Dissoluçấo diferencial em geminado (x 25); e. Estrutura zonada em geminado (x 40); f. Inclusōes de olivina isorientadas ( $x 50$ ); $\mathrm{g}$. Inclusão de olivina equidimensional (x 100); h. Inclusão de granada com faces estriadas (x 50). 
Admitindo-se, por motivos já expostos, que devem ser raros os cristais que apresentem figuras de crescimento em escala microscópica, a maioria dos trí gonos observados deve originar-se de dissolução, orientando-se opostamente devido talvez à lentidão do processo natural. De outro lado, a distribuição regular destas figuras, ao longo de possíveis defeitos lineares em(111) (Prancha If ) e a sua presença em planos de clivagem (Prancha Ig), dificilmente podem ser explicadas pelo crescimento cristalino.

Em cristais onde se observam trígonos isorientados, êstes se apresentam ora numerosos e pouco desenvolvidos (Prancha Ih), o que denota maior intensidade da corrosão, ora de maneira esparsa, ocorrendo ao lado de figuras em oposição (Prancha II a ). A interação dêstes dois processos corrosivos simultâneamente, poderia originar as cavidades de contôrno hexagonal. É possível, também, admitir a orientação anômala dos trígonos como resultado de geminação em escala microscópica, o que, na realidade, se observa em alguns geminados de contôrno octaédrico, onde ocorrem trígonos isorientados.

Além dos trígonos, alguns cristais exibem lineamentos formando padrão reticulado hexagonal, resultante, talvez, de impacto, que poderia ter provocado o aparecimento de fendas de clivagem, ao longo dos planos (111) (Prancha II b ).

\section{Faces de rombododecaedro}

As marcas superficiais, nas faces de rombododecaedro, não apresentam a regularidade das figuras observadas em (111) e sua origem pode ser interpretada de diversos modos, mas admitindo-se sempre que a feição final resulte da dissolução. Assim, nas faces (110) planas, podem-se verificar estrias paralelas, ao longo da sua diagonal maior, originadas, inicialmente, pelo crescimento, segundo faces vicinais do tipo (111). Estas estrias, observadas mesmo a ôlho nu, denotam, com maior ou menor in- tensidade, o efeito da corrosão, o que se verifica ao microscópio, pelo seu arredondamento, a ponto de se transformarem em colinas grosseiramente elípticas e muito alongadas (Prancha II c) .

Em apenas uma amostra, parcialmente recoberta por película verde e transparente ("coated diamond"), os planos de rombododecaedro apresentavam superfície escabrosa, resultante da interrupção das estrias, por planos (100), formando colinas de contôrno geométrico definido e delimitadas por faces de cubo e octaedro, onde se pode notar a presença de pequenos trígonos (Prancha II c ). No tôpo de algumas destas elevações, é possível encontrarem-se faces (110) estriadas e pouco desenvolvidas.

Nas superfícies (110) dos cristais arredondados, as colinas elípticas acima descritas tornam-se menos alongadas, mostrando-se mais regulares nas proximidades dos vértices quádruplos, que podem ser interpretadas como testemunhos de contôrno octaédrico (Prancha II d ). Uma dissolução mais intensa, pode, no entanto, arredondá-las, tirando-lhes esta característica. As figuras dêste tipo são facilmente explicadas pela dissolução diferencial: as camadas estruturalmente mais perfeitas, serão também as mais resistentes à corrosão e, dêste modo, podem aflorar na superfície rombo dodecaédrica recurvada. Esta interpretação pode ser admitida pelo diferente comportamento dos diamantes do tipo I e do tipo II, quando submetidos à dissolução (Halperin, 1956), e pela presença, no mesmo cristal, de camadas de ambos os tipos (Tolansky, 1966). Alguns autores, no entanto (Williams, 1932; Tolansky, 1960), não admitem esta suposição e consideram o crescimento cristalino como responsável pela origem destas figuras.

Muitas vêzes, estas marcas são microscópicas e agrupam-se regularmente, revelando a estrutura zonada do cristal, originada pela flutuação das condições ambientes, durante o crescimento, o que resulta na deposição de camadas com diferentes resistências à corrosão. Estru- 
turas dêste tipo já foram observadas em secções paralelas a (100), artificialmente corroídas (Seal, 1965), onde se notam níveis de crescimento formando $90^{\circ}$ entre si e interrompidos, em seus vértices, pela face curva do cristal. A projeção destas camadas, sôbre a superfície rombododecaédrica recurvada, apresenta contôrno pseudo-hexagonal, com bordos arredondados (Prancha IIf) e a única maneira de explicar estas figuras é admitir a face (110) como conseqüência de dissolução.

Algumas vêzes, a estrutura zonada não se apresenta bem definida e os níveis de crescimento mostram-se entrelaçados, o que provoca o aparecimento de uma estrutura reticular, cuja origem, segundo Fersman e Goldschmidt (1911), deve-se à geminação polissintética, porém não comprovada experimentalmente. Williams (1932), já as interpreta como efeito de deslizamento, durante a cristalização, o que é pouco provável, pelas propriedades mecânicas incomuns do diamante. Uma interpretação, talvez mais segura, poderia considerar a migração dos defeitos cristalinos dos níveis de crescimento, que, dêste modo, se distribuiram por todo o plano (111), após a cristalização. A corrosão ulterior revelaria, então, o entrelaçamento das lineações .

Em algumas amostras, as figuras características da superfície rombododecaédrica apresentam-se de maneira anômala (Prancha II g), e orientadas diferentemente, como os trígonos. Nos cristais onde ocorrem, podem-se também observar trígonos em concordância, o que talvez explique a sua origem por um processo corrosivo mais intenso.

Além destas figuras, observadas na superfície de quase todos os cristais rombododecaédricos, em algumas amostras onde as faces se apresentam extremamente lisas, observam-se figuras de impacto, semelhantes às que ocorrem em (111). No entanto, o contôrno é agora pseudo-hexagonal ou losangular, delimitado pela projeção da clivagem octaédrica no plano (110) .
É possível, ainda, encontrar, nas superfícies (110) mais perfeitas, pequenas marcas circulares (microdiscos) (Prancha $\mathrm{II} \mathrm{h}$ ), originadas pela proteção, durante o ataque químico, por bôlhas de gás, aderentes à superfície do cristal (Tolansky, 1960). Contudo, algumas destas figuras apresentam-se como círculos absolutamente perfeitos, com pequena cavidade localizada no centro (Prancha III a), e aparecem originadas de processo diverso.

\section{Faces de cubo}

Nas faces de cubo, sempre ocorrem figuras características, como os trígonos. São cavidades de contôrno quadrado ou retangular, escalonadas ou piramidais (Prancha III b ). As medidas interferométricas, neste caso, foram impraticáveis, pela irregularidade da superfície (100), não se podendo tomá-la como plano de referência. Contudo, parecem pouco profundas, em relação à área superficial e, conseqüentemente, os planos piramidais devem apresentar índices millerianos elevados. Estas cavidades sempre se encontram orientadas, a $45^{\circ}$ das arestas [100] e figuras semelhantes, obtidas por corrosão artifical, mas orientadas paralelamente às arestas do cubo, sugeriram a Williams (1932) interpretá-las como originadas por crescimento cristalino. As mesmas considerações admitidas nos casos anteriores, são talvez cabíveis aqui: as figuras de crescimento, na superfície de diamantes naturais, devem ser improváveis, e as diferentes orientações das figuras poderiam ser explicadas por processos corrosivos diversos.

Nas faces de alguns cristais cúbicos, onde a superfície (100) se mostra mais regular, é possível notar figuras de impacto, de padrão retangular, originadas pelas projeções das clivagens (111), no plano do cubo.

\section{Estruturas de superfícies em geminados}

Em exemplares geminados, ocorrem as mesmas figuras já descritas nos indivíduos isolados; no entanto, ao longo da 
superfície de contacto dos dois cristais, observa-se uma interferência entre as figuras de corrosão, resultando daí estruturas características, denominadas "suturas" ou "costuras" (Prancha III c). Âs vêzes, é possível identificar os indivíduos, pelo diferente comportamento que apresentam, quanto à dissolução natural (Prancha III d) .

As estruturas mais interessantes são, no entanto, originadas pela interação das estruturas zonadas dos dois cristais geminados, dando em resultado padrões complexos, de difícil interpretação. Porém, algumas destas estruturas, mostram, distintamente, o zoneamento de cada um dos indivíduos (Prancha III e). Neste caso, nota-se também a estrutura reticular, complicada pela presença de dois cristais. E freqüente, ainda, encontrarem-se lineações, formando ângulos de $15^{\circ}$, que podem ser explicadas tal como a estrutura reticular da face (110).

\section{ESPECTROSCOPIA}

\section{Espectrografia de absorção às radiações infravermelhas}

A classificação do diamante, segundo os tipos, Ia, Ib, IIa e IIb, é possível pelos espectros de absorção aos raios infravermelhos. As frequiências das vibrações, no retículo cristalino do diamante ideal, (tipo IIa) devem se estender, teòricamente, de $1.400 \mathrm{~cm}^{-1}$ até 300 $\mathrm{cm}^{-1}$ (Sutherland, Blackwell e Simeral, 1954). A distribuição das frequiências fundamentais é, no entanto, mais difícil de precisar, e nem tôdas participam efetivamente da absorção, aparecendo, na realidade, bandas de absorção resultantes de combinações dessas freqüências. Assim, os diamantes do tipo II, absorvem nas regiões de $1.800 \mathrm{~cm}^{-1}$ e 200 $\mathrm{cm}^{-1}$, que correspondem às frequiências fundamentais, apresentando, ainda, na região das combinações, picos de absorção entre $1.800 \mathrm{~cm}^{-1}$ e $3.500 \mathrm{~cm}^{-1}$. Qualquer defeito cristalino que modifique a simetria entre dois átomos de carbono, pode originar frequiências diferentes, sob forma de absorção anômala, abaixo de $1.800 \mathrm{~cm}^{-1}$.

As bandas de absorção comuns a todos os diamantes, são atribuídas ao processo fonon-2 (de 2.000 a $2.500 \mathrm{~cm}^{-1}$ ) e fonon-3 ( de 3.100 a $3.500 \mathrm{~cm}^{-1}$ ), estando os picos característicos localizados nas frequiências de $1.977,2.034$, $2.160,2.400$ e $2.920 \mathrm{~cm}^{-1}$ (Charette, 1961; Wedephol, 1957).

Os diamantes impuros (tipos Ia e Ib), apresentam absorção anômala, entre 1.540 e $328 \mathrm{~cm}^{-1}$, e, mesmo antes da subdivisão dos diamantes do tipo I em Ia e Ib, Sutherland et al. (1954), já haviam notado que estas bandas poderiam se situar em dois grupos A e B, quanto à variação das intensidades relativas dos picos de absorção. Dêste modo, as bandas do grupo A, mais largas e correspondentes aos diamantes Ia, localizam-se em 1.282, 1.203, $1.093 \mathrm{e}$ $480 \mathrm{~cm}^{-1}$, enquanto que os diamantes $\mathrm{Ib}$, apresentando o sistema de absorção $\mathrm{B}$, mostram picos bem pronunciados em $1.426,1.372$ e $328 \mathrm{~cm}^{-1}$, absorvendo ainda, nas regiões de $1.171,1.003 \mathrm{e}$ $780 \mathrm{~cm}^{-1}$. Os picos observados a 1.520 e $1.540 \mathrm{~cm}^{-1}$ parecem não se relacionar com nenhum dos tipos considerados.

Os diamantes IIb apresentam as mesmas bandas de IIa e absorvem quase continuamente, entre 20.000 e 3.330 $\mathrm{cm}^{-1}$. Os picos mais definidos (Wedephol, 1957), localizaram-se em 2.915, $2.809,2.793$ e $2.457 \mathrm{~cm}^{1}$.

Os espectros onde figuram apenas picos característicos de sòmente um tipo de diamante, são raramente observados, ocorrendo mais comumente, a sobreposição das bandas de absorção de mais de um tipo. Entretanto, a atual classificação dos diamantes, é procedente (Du Preez e Raal, 1965), pois a maioria dos cristais mostra, nos espectros, de absorção IV ou UV, a predominância de um tipo único.

O estudo espectrográfico dos diaman- 
tes provenientes do Triângulo Mineiro, foi efetuado com 39 amostras transparentes, de diferentes hábitos e colorações, com o objetivo de relacionar essas propriedades com os tipos já mencionados. $\mathrm{O}$ método experimental utilizado e aplicável ao material bruto, limitou, no entanto, o tamanho das amostras, entre 0,1 e 0,4 quilates métricos, o que pode interferir na freqüência dos diversos tipos, no lote estudado. Além disso, a irregularidade dos exemplares, provocando reflexões internas, pode originar interferências de pseudo-absorções, o que dificulta a interpretação dos diagramas, sem influir, contudo, nos resultados observados.

Nos espectrogramas obtidos, compreendendo o intervalo de 4.000 e $670 \mathrm{~cm}^{-1}$, verificou-se a presença de picos bem pronunciados e, entre essas bandas, qua- se tôdas se situam nas regiões de absorção de cada tipo. No entanto, os picos a $3.230,3.100,2.320$ e $870 \mathrm{~cm}^{-1}$, observados em pequeno número de amostras, parecem não ter sido anteriormente encontrados. A absorção em 3.230 $\mathrm{cm}^{-1}$ foi verificada em apenas dois exemplares do tipo I, apresentando faces (100) pouco desenvolvidas e coloração verde-azulada. No entanto, nem tôdas as amostras azuis ou verdes e mostrando faces de cubo, absorvem nesta frequiência. A absorção na região de $3.100 \mathrm{~cm}^{-1}$ parece não se relacionar com a côr ou com a morfologia, e ocorre sòmente em diamante do tipo I. O pico a 2.320 $\mathrm{cm}^{-1}$ foi observado em duas amostra3, uma de coloração verde-amarelado e aspecto opalescente, e outra parcialmente recoberta por película transparente de côr verde. Um espectro, obtido com o

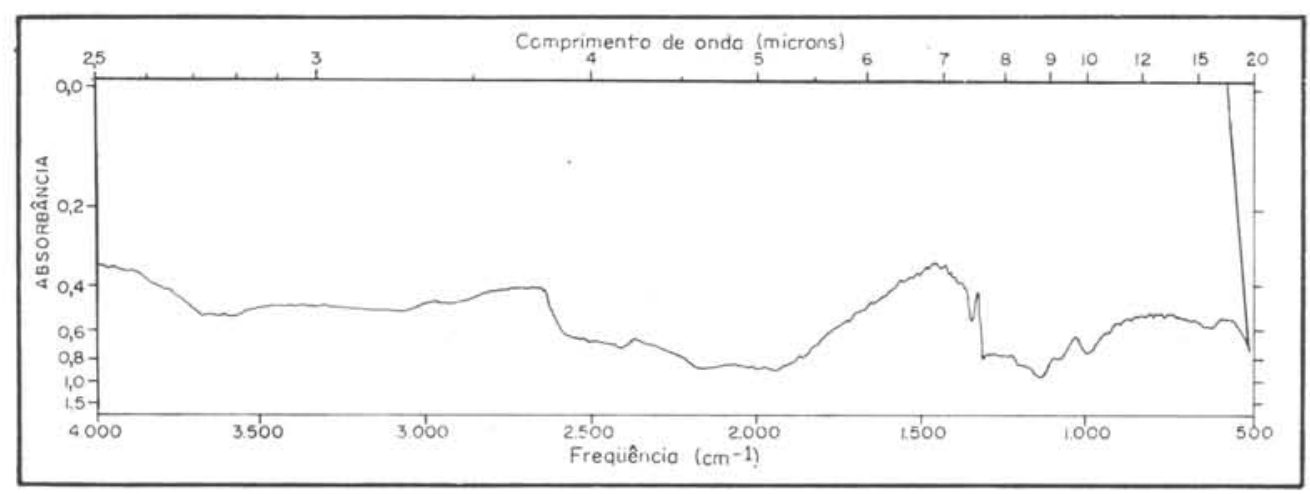

a

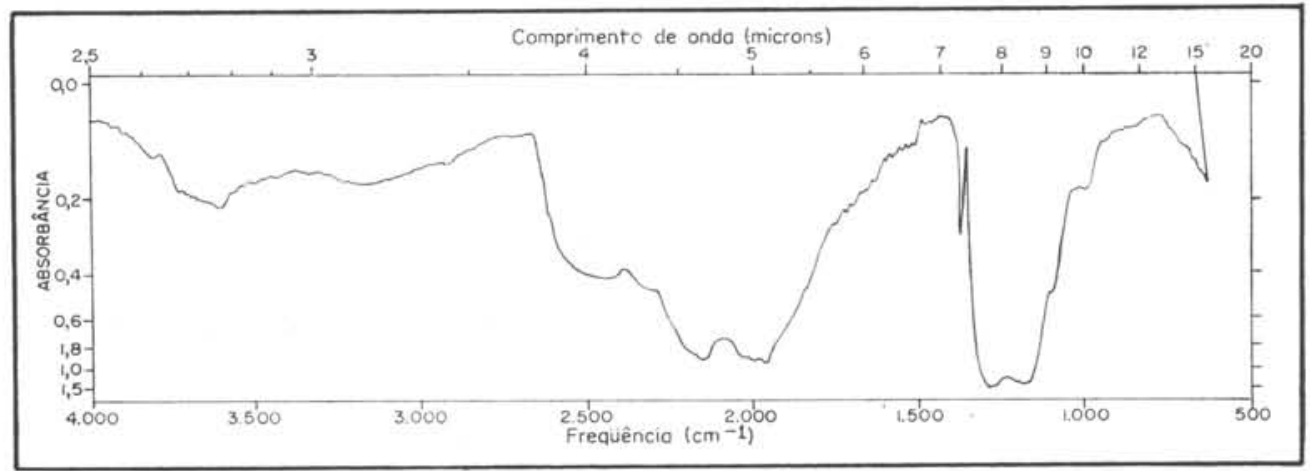

b

Figura 7 - a. Espectro de absorção infravermelho de diamante do tipo II; b. idem, diamante do tipo Ia. 


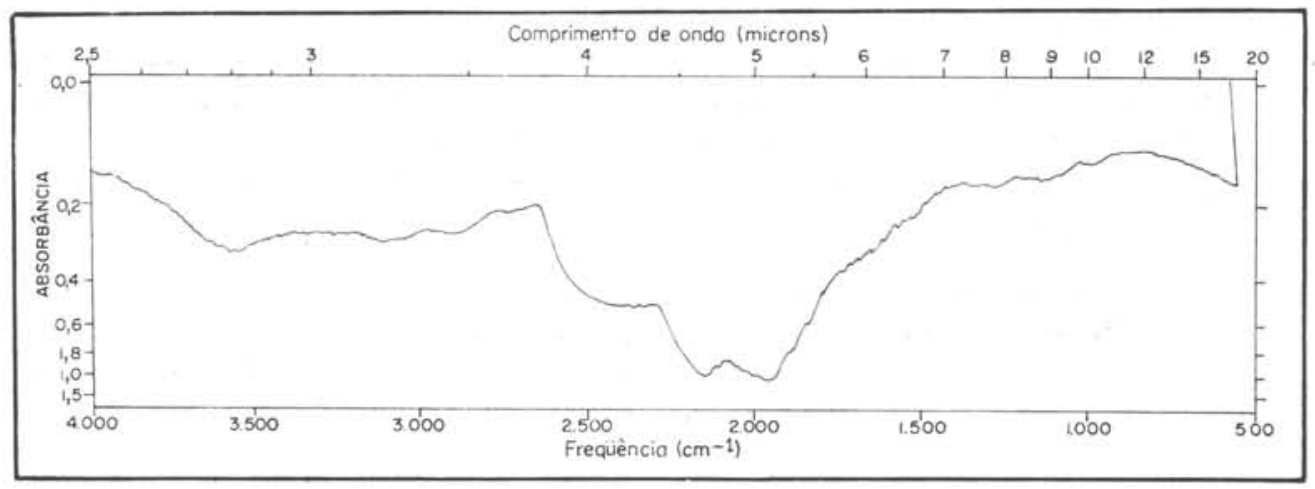

a

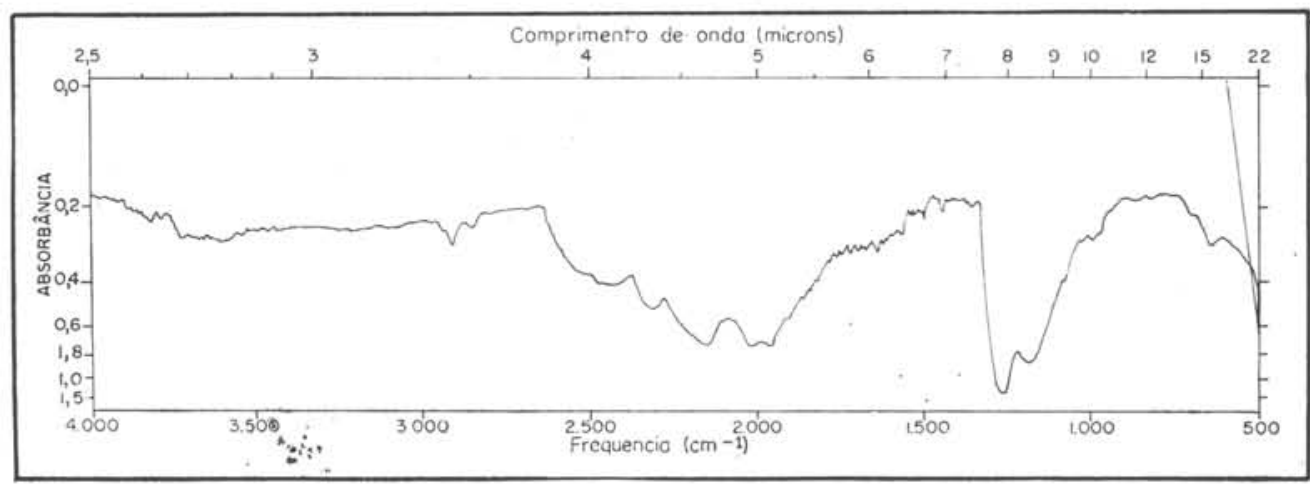

b

Figura 8 - a. Espectro de absorção infravermelho do diamante do tipo Ib; b. idem, diamante intermediário Ia-Ib.

feixe percorrendo a parte incolor dêste último exemplar, não apresentou absorção nessa frequiência. A absorção a 870 $\mathrm{cm}^{-1}$ foi verificada em amostras que apresentavam inclusões microscópicas, podendo, portanto, ser explicadas pela presenças dessas impurezas.

A distinção dos diamantes I e II pope-se efetuar pela ausência de absorção abaixo de $.800 \mathrm{~cm}^{-1}$, nos diamantes do tipo II (Figura 7a), sendo possível, no entanto, a ocorrência de tipos intermediários, com bandas pouco pronunciadas na região de 7 a $9 \mu$. Os diamantes do tipo Ia e Ib (Figuras $7 \mathrm{~b}$ e $8 \mathrm{a}$ ) podem distinguir-se quanto à intensidade relativa dos picos, a $1.370,1.281$ e 1.170 $\mathrm{cm}^{-1}$ (Du Preez e Raal, 1965). Porém diamantes apresentatando sòmente as absorções características do grupo B, não foram observados, encontrando-se ape- nas os tipos intermediários entre Ia e $\mathrm{Ib}$, com predominância do tipo Ib (Figura 8a). Muitos dêstes diamantes são difìcilmente caracterizados, pela equivalência das intensidades relativas das bandas do grupo A e B e foram considerados como tipos intermediários (Figura $8 b)$. Os diamantes característicos do tipo Ia são mais fàcilmente encontrados e os espectrogramas mostram a interferência quase desprezível das bandas do sistema B.

A ocorrência dos diversos tipos, entre os diamantes do Triângulo Mineiro, é mostrada na Tabela 5 , onde se nota a ausência de cristais do tipo IIb, não encontrados no lote estudado. Pode-se verificar, ainda, a freqüência anômala de diamantes do tipo II, talvez explicável pelo tamanho reduzido das amostras, pois os cristais menos desenvolvidos são fisicamente os mais perfeitos (Tolansky, 
1967). Os diamantes do tipo Ib, raros entre os diamantes naturais, mostram-se freqüientes nos exemplares do Triângulo, o que pode constituir um elemento seguro para a sua caracterização.

Tabela 5

Distribuição dos diamantes quanto ao tipo

Tipo

Ia

$\mathrm{Ib}$

Intermediário

$\mathrm{Ia}-\mathrm{Ib}$

IIa

Intermediário

I-II

15
Frequiência (em \%)

26

6

15

10

\begin{tabular}{lr} 
Ia-Ib & 38 \\
IIa & 5 \\
Intermediário & \\
I-II & 13 \\
\hline
\end{tabular}

\section{Fluorescência ao Ultravioleta}

Os diamantes, geralmente do tipo I, podem apresentar fluorescência azul ou verde, sendo as bandas de emissão centradas em $4.150 \stackrel{\circ}{\mathrm{e}} 5.032 \stackrel{\circ}{\AA}$, estendendo-se para regiões de comprimentos de onda mais curtos (Mitchell, 1964).

Cêrca de $32 \%$ das amostras do Triângulo Mineiro, quando submetidas à ultravioleta, mostram fluorescência azul, verde e amarelo-alaranjado, sendo, esta última, talvez devida à cauda de um terceiro sistema de emissão, situado além do visível, com centro em $7.140 \stackrel{\AA}{\AA}$.
Muitas vêzes, a luminescência parece concentrar-se em pequenas áreas, ao redor de inclusões, ou na superfície de contacto de geminados.

Os diamantes que exibem fluorescência azul, na maioria incolores, são geralmente fosforescentes, e êste caráter se acentua nas amostras que apresentam fluorescência mais intensa. Em cristais verde-amarelados ou branco-amarelados, pode-se encontrar a fluorescência verde. Neste caso, sòmente as amostras que apresentam forte luminescência, são também ligeiramente fosforescentes. A fluorescência amarelo-alaranjado, raramente observada, é pouco intensa e restringe-se a regiões limitadas no cristal.

A tabela 6 mostra a distribuição em percentagem dos diversos tipos de fluorescência. A precariedade do método experimental impediu incluir os cristais que apresentam fluorescência pouco intensa, imperceptível pela simples observação. Dêste modo, um estudo com maiores recursos, poderá revelar maior ocorrência de amostras fluorescentes.

\section{Tabela 6}

Distribuição dos diamantes quanto à fluorescência

Fluorescência

Freqüêneia

Azul (em \%)

Verde

Amarelo-alaranjado

\section{INCLUSÕES}

As inclusões em diamantes são conhecidas desde o século passado e a sua identificação, até bem pouco tempo, era efetuada por simples observação à lupa ou ao microscópio, o que conduzia, muitas vêzes, a resultados pouco seguros. Além disso, não havia preocupação em se distinguirem as inclusões singenéticas, formadas simultâneamente com o diamante, das inclusões epigenéticas, originadas "a posteriori" e que preenchem fendas e cavidades do hospedeiro. Dêste modo, a interpretação das associações paragenéticas não poderia indicar, com segurança, as condições ambientes na formação do diamante.

Wagner (1914), através da microscopia óptica, identificou o diopsídio e o piropo, como inclusões freqüentes em diamantes sul-africanos. Sutton (1921), estudando diamantes da mesma região, acrescentou a granada, a ilmenita, a oli- 
vina e a pirita, mencionando, ainda, como inclusões prováveis, o zircão e a mica. Estes minerais foram por êle considerados inclusões preformadas, pois podem ocorrer como hospedeiros do diamante. A grafita e o próprio diamante, também encontrados, foram classificados como inclusões contemporâneas .

Em 1923, Colony descreveu a presença de cristais de quartzo, desenvolvendo-se juntamente com material detrítico de coloração verde, ao longo de planos de clivagem, em diamantes provenientes do Brasil. Esta associação fêz com que se acreditasse estar o diamante brasileiro genèticamente ligado a rochas àcidas (Guimarães, 1934).

Friedel (1923), descreveu a ocorrência de grafita, já mencionada por Sutton (1921); e a presença de magnetita, sob a forma de cristais octaédricos e magnéticos, foi notada por Spencer (1924).

Muitas inclusões negras, comuns em diamante, segundo Williams (1932), devem ser partículas do magma original, englobados pelo hospedeiro. Êste Autor descreveu, além dos minerais já anteriormente citados, a ocorrência de piroxênio e mica, de composição não determinada, em diamantes da África do Sul.

Ëm estudo sistemático, aplicando, porém, apenas recursos ópticos, Gubelin (1952), classifica as inclusões em preformadas: olivina, granada, enstatita, magnetita, diopsídio, zircão, grafita, biotita, clorita e flogopita; e contemporâneas: granada, crosmoespinélio, magnetita, ilmenita, hematita, zircão, grafita e, talvez, enstatita, além do próprio diamante. No mesmo trabalho, o Autor ainda menciona a presença de quartzo, em diamantes brasileiros, não esclarecendo, contudo, tratar-se de inclusão preformada ou contemporânea .

A identificação das inclusões, aplicando meios mais seguros, foi introduzida por Giardini e Mitchell (1953), quando se observou a presença de cristais de olivina orientados em diamantes, através da difração de raios $\mathrm{X}$, empregando-se o método de Weissemberg. Pouco depois, Autores russos (Futergendler, 1956 e
1958; Nikolaeva, 1958; Orlof, 1959; Futergendler e Frank-Kamanetskii, 1961), também confirmaram, por difração de raios X (método de Laue), a ocorrência de granada, diopsídio, cromoespinélio, diamante, além da olivina, em amostras dos depósitos dos Urais e da Sibéria. Orlof (1959), cita, ainda, a serpentina, a grafita e a goethita, como inclusões epigenéticas.

A coesita, variedade polimórfica da sílica, estável a altas pressões, pode também ocorrer como inclusão de diamantes sintéticos (Milledge, 1961).

Eppler (1961), em trabalho semelhante ao desenvolvido por Gubelin (1952), acrescenta a apatita, entre as inclusões. Porém, a caracterização dêste mineral, através apenas de um de seus índices de refração $(=1,6585)$, é pouco segura $\mathbf{e}$ ainda não foi confirmada em diagramas de difração de raios $\mathbf{X}$.

A ocorrência de pirrotita, pentlandita e cohenita, em diamantes sul-africanos, foi nota por Sharp (1966), que as considera como epigenéticas e talvez originadas pela exsolução de sulfetos mais estáveis e altas pressões, incluídos pelo diamante durante a cristalização.

Camargo e Leite (1968), através da difração de raios $\mathrm{X}$ (método da precessão), identificaram a olivina como inclusão de diamantes brasileiros.

Utilizando também a difração de raios X (método de Laue), Harris (1968) identificou vinte e duas espécies minerais, como inclusões de diamantes da África do Sul, Ghana e Serra Leoa. As inclusões singenéticas encontradas, foram: diamantes, coesita, olivina, enstatita, granada, diopsídio, magnetita, ilmenita, cromoespinélio, rutilo e brookita, sendo, estas duas últimas, já citadas por Gnevushev e Nikolaeva (1961). As inclusões epigenéticas foram divididas, pelo Autor, em três grupos, com diferentes modos de ocorrência:

a. agregados policristalinos ou cristais alotriomorfos: goethita, quartzo e, possivelmente, moscovita;

b. agregados policristalinos, desen- 
volvendo-se ao redor de inclusões singenéticas: grafita, pirrotita e pentlandita;

c. minerais que preenchem fendas e planos de clivagem: calcita, hematita, caulinita, sellaita e xenotima.

Os minerais dos dois primeiros grupos encontram-se totalmente incluídos no hospedeiro, não se comunicando com a superfície, através de fendas visíveis. Segundo o Autor, devem ser considerados epigenéticos, pela sua instabilidade sob pressões e temperaturas elevadas, originados, talvez, de processos de exsołução ou transformação polimórfica .

Para a identificação das inclusões dos diamantes do Triângulo Mineiro, selecionou-se, ao microscópio e à lupa binocular, cêrca de 39 amostras que foram, posteriormente, submetidas à difração de raios $\mathrm{X}$. Estes exemplares mostravam inclusões totalmente englobadas pelo diamante, não se comunicando com a superfície do cristal, por meio de fendas observáveis, mesmo ao microscópio, com aumento aproximado de $240 x$. Dêste modo, as inclusões estudadas podem ser tanto singenéticas como epigenéticas, mas revelam sòmente o material incluído pelo hospedeiro, durante o crescimento dêste. Em algumas amostras, onde se observa, ao lado de inclusões dêste tipo, a presença de material detrítico, em fendas ou cavidades, os diagramas de raios $\mathrm{X}$ podem mostrar também as raias características de agregados policristalinos.

As inclusões identificadas: olivina, granada, cromoespinélio, pentlandita e diamante, serão descritas a seguir.

\section{Olivina}

As olivinas, principalmente as de composição química mais próxima da forsterita, são as inclusões heterogêneas mais comuns, no diamante. Ocorrem, geralmente como cristais incolores, e, quando bem desenvolvidos ( $0,5 \mathrm{~mm}$ no máximo), podem ser fàcilmente observados, mesmo à vista desarmada, constituindo o que os garimpeiros denominam "bôlhas", o que se deve ao seu pequeno índice de refração ( $\beta=1,651)$, quando comparado ao do hospedeiro $(\mathrm{n}=2,41)$. São raras as amostras de diamante que apresentam sòmente um cristal incluído, sendo mais frequiente a presença de um grupo de três ou mais indivíduos, muitas vêzes isorientados (Prancha IIIf). Em alguns diamantes, pode mesmo ocorrer um grande número dessas inclusões, porém pouco desenvolvidas e associadas a inclusões negras, não identificadas. A presença de olivina, sob a forma de poeira cristalina, já foi assinalada por Gnevushev e Futergendler (1963).

As inclusões de olivina, bem como outras, podem provocar tensões internas no hospedeiro, devido aos diferentes coeficientes de dilatação térmica. Dêste modo, muitas delas ocorrem sempre associadas a fendas de tensão que se assemelham, ao microscópio, a inclusões negras de forma placóide ou irregular. Se estas fendas se desenvolvem no hospedeiro, o alívio de tensão pode provocar a fragmentação do cristal incluido, que se torna quase opaco. Estas tensões são responsáveis também pela birrefringência anômala do diamante, o que dificulta a determinação do caráter mono ou birrefringente da inclusão.

\section{a. Morfologia}

Os cristais incluídos apresentam, comumente, formas geométricas definidas, segundo hábitos equidimensionais, tabulares ou alongados, ocorrendo sempre um arredondamento das arestas, devido talvez ao crescimento segundo faces vicinais. É possível, contudo, encontrarem-se cristais irregulares, que podem assumir formas estranhas, fato já ressaltado por Eppler (1961). As formas equidimensionais podem apresentar arestas bem pronunciadas e a face mais desenvolvida nesses cristais tem formato pseudo-hexagonal (Prancha III g). Os cristais tabulares já são mais arredondados, e, em indivíduos alongados, pode-se também notar o contôrno pseudo-hexagonal. Esta propriedade talvez seja o principal caráter distintivo da olivina, pois sempre se observa, ao microscópio polarizador e com nícois cruzados, extinção reta ou simétrica nos cristais tabulares e equi- 
dimensionais ou extinção a $35^{\circ}$ da direção de maior desenvolvimento nos cristais alongados.

Quando separados do hospedeiro, os cristais de olivina fraturam-se fàcilmente, e, devido ao seu pequeno tamanho, foram mal sucedidas as tentativas para obtenção de medidas goniométricas. No entanto, pelo menos nas inclusões equidimensionais, uma das faces mais desenvolvidas é (100), pela orientação da figura de interferência.

\section{b. Difração de raios $\mathrm{X}$}

Entre as 230 amostras estudadas, 31 diamantes apresentam, ao microscópio, inclusões com as características acima descritas. Dentre êstes exemplares, seis foram selecionados para o exame aos raios X (método da precessão): amostra 1 (Rio Dourados); amostra 11 (Rio Dourados); amostra 13 (Rio Indaiá); amostra 18 (sem procedência segura); amostra 34 (Rio Santo Inácio) e amostra 35 (Rio Douradinho). As distâncias interplanares e os ângulos entre as direções do retículo recíproco, determinados sôbre diagramas de precessão permitiram a determinação dos índices das reflexões observadas, constantes na Tabela 7 , procedendo-se de maneira já descrita anteriormente. Nesta operação, utilizou-se a projeção estereográfica da forsterita, obtida com os valôres angulares tabulados por Dana (1920).

Os "d"s observados possibilitaram o cálculo das constantes reticulares das inclusões de olivina, aplicando-se, para o refinamento dêstes parâmetros, o método gráfico-analítico (Camargo e Inglez, 1967), ligeiramente modificado. Por êste método, a determinação dos parâmetros unitários de cristais rômbicos é possível, tomando-se três reflexões próximas e de índices quaisquer, o que resulta num sistema de três equações, onde as incógnitas são as constantes procuradas. Considerando-se, no entanto, a relação paramétrica fundamental como aproximada- mente conhecida (caso de têrmos de séries isomorfas), êste procedimento é dispensável e os parâmetros podem ser obtidos através de apenas uma equação. Assim, tomando-se uma reflexão (hk $\ell$ ) qualquer, é possível calcular as constantes reticulares pelas expressões:

$$
\begin{aligned}
& \mathrm{a}_{\mathrm{o}}=\mathrm{a} \cdot \mathrm{d}_{\mathrm{hk \ell},} \cdot \mathrm{N} \\
& \mathrm{b}_{\mathrm{o}}=\mathrm{d}_{\mathrm{hk \ell},} \cdot \mathrm{N} \\
& \mathrm{c}_{\mathrm{o}}=\mathrm{c} \cdot \mathrm{d}_{\mathrm{hk \ell} \ell} \cdot \mathrm{N}
\end{aligned}
$$

onde $a$ e $c$ são os têrmos da relação paramétrica fundamental $\mathrm{a}: \mathrm{b}: \mathrm{c}$, que, no caso da forsterita é igual a $0,467: 1$ : 0,587 (Dana, 1920),

$$
\text { e } \mathrm{N}=\sqrt{\mathrm{h}^{2} / \mathrm{a}^{2}+\mathrm{k}^{2} / \mathrm{b}^{2}+\mathrm{l}^{2} / \mathrm{c}^{2}}
$$

Os parâmetros obtidos desta forma foram, posteriormente, extrapolados, segundo o procedimento normal do método gráfico-analítico, após a verificação de sua aplicabilidade em diagramas de precessão (Camargo et al., 1969). Os $\mathrm{d}_{\mathrm{hk} \ell}$ teóricos, calculados a partir dêstes parâmetros unitários extrapolados e constantes na Tabela 8, são mostrados juntamente com os $\mathrm{d}_{\mathrm{hk \ell}}$ observados na Tabela 7 , onde se pode notar a concordância com os dados experimentais obtidos .

\section{c. Composição química}

A composição química das inclusões pode ser fàcilmente determinada, a partir dos parâmetros da cela unitária, pois estas constantes aumentam, contìnuamente, na medida em que o $\mathrm{Mg}$ é substituído pelo $\mathrm{Fe}$. Um dos métodos utilizados nesta determinação consiste em obter-se o valor do espaçamento entre os planos (130) e aplicá-los na equação da curva determinativa, estabelecida por Yoder e Sahama (1957), onde a composição é dada por:

$$
\begin{aligned}
\text { Fo }(\mathrm{mol} \%) & =4233,91-1494,59 \cdot \mathrm{d}_{130} \\
& -139-
\end{aligned}
$$


Tabela 7

Distâncias interplanares das inclusões de olivina

\begin{tabular}{|c|c|c|c|c|c|c|c|c|}
\hline \multicolumn{3}{|c|}{ Amostra 1} & \multicolumn{3}{|c|}{ Amostra 11} & \multicolumn{3}{|c|}{ Amostra 13} \\
\hline & $\mathrm{d}_{\mathrm{hk \ell} \ell}$ & $(\stackrel{\circ}{\AA})$ & & $\mathrm{d}_{\mathrm{hk} \ell}$ & $(\stackrel{\circ}{\AA})$ & & $\mathrm{d}_{\mathrm{hk} \ell}$ & $(\stackrel{\circ}{\AA})$ \\
\hline hk $\ell$ & obs & calc & hk $\ell$ & obs & calc & $\mathrm{hk} \ell$ & obs & calc \\
\hline 020 & 5,144 & 5,177 & 021 & 3,876 & 3,880 & 101 & 3,741 & 3,738 \\
\hline 021 & 3,905 & 3,895 & 101 & 3,735 & 3,720 & $\begin{array}{l}120 \\
121\end{array}$ & $\begin{array}{l}3,495 \\
3,024\end{array}$ & $\begin{array}{l}3,488 \\
3,017\end{array}$ \\
\hline 101 & 3,750 & 3,736 & 130 & 2,762 & 2,765 & 002 & 3,003 & 3,003 \\
\hline 111 & 3,532 & 3,510 & 022 & 2,576 & 2,579 & $\begin{array}{l}130 \\
131\end{array}$ & 2,787 & 2,774 \\
\hline 120 & 3,502 & 3,490 & 112 & 2,458 & 2,456 & $\begin{array}{l}131 \\
112\end{array}$ & $\begin{array}{l}2,519 \\
2,458\end{array}$ & $\begin{array}{l}2,518 \\
2,467\end{array}$ \\
\hline & & & 112 & $2,+70$ & 2,430 & 041 & 2,356 & 2,352 \\
\hline 130 & 2,770 & 2,775 & 140 & 2,244 & 2,247 & 122 & 2,280 & 2,276 \\
\hline 022 & 2,606 & 2,592 & 023 & 1,854 & 1,857 & $\begin{array}{l}211 \\
132\end{array}$ & $\begin{array}{l}2,165 \\
2,040\end{array}$ & $\begin{array}{l}2,168 \\
2,038\end{array}$ \\
\hline 131 & 2,520 & 2,524 & 133 & 1,618 & 1,617 & 222 & 1,758 & 1,755 \\
\hline 112 & 2,471 & 2,469 & 062 & 1,478 & 1,478 & $\begin{array}{l}240 \\
241\end{array}$ & $\begin{array}{l}1,755 \\
1,682\end{array}$ & $\begin{array}{l}1,745 \\
1.675\end{array}$ \\
\hline 122 & 2,281 & 2,278 & 170 & 1,393 & 1,393 & 242 & $\begin{array}{l}1,002 \\
1,509\end{array}$ & 1,508 \\
\hline \multirow[t]{2}{*}{211} & 2,169 & 2,168 & & & & $\begin{array}{l}062 \\
333\end{array}$ & $\begin{array}{l}1,478 \\
1,163\end{array}$ & $\begin{array}{l}1,482 \\
1,170\end{array}$ \\
\hline & & & & & & $\begin{array}{l}333 \\
244\end{array}$ & $\begin{array}{l}1,163 \\
1,143\end{array}$ & $\begin{array}{l}1,170 \\
1,138\end{array}$ \\
\hline \multicolumn{3}{|c|}{ Amostra 18} & \multicolumn{3}{|c|}{ Amostra 34} & \multicolumn{3}{|c|}{ Amostra 35} \\
\hline & $\mathrm{d}_{\mathrm{hk \ell} \ell}$ & $(\stackrel{\circ}{\AA})$ & & $\mathrm{d}_{\mathrm{hk} \ell}$ & $\left(\begin{array}{l}0 \\
\AA\end{array}\right)$ & & $\mathrm{d}_{\mathrm{hk} \ell}$ & $(\stackrel{\circ}{\AA})$ \\
\hline hk $\ell$ & obs & calc & hk $\ell$ & obs & calc & hk $\ell$ & obs & calc \\
\hline 021 & 3,877 & 3,877 & 021 & 3,903 & 3,891 & 111 & 3,495 & 3,497 \\
\hline 101 & 3,725 & 3,725 & $\begin{array}{l}101 \\
120\end{array}$ & $\begin{array}{l}3,737 \\
3,485\end{array}$ & $\begin{array}{l}3,733 \\
3,485\end{array}$ & 130 & 2,769 & 2,764 \\
\hline 112 & 2,458 & 2,457 & 122 & 2,273 & 2,273 & 112 & 2,457 & 2,457 \\
\hline 122 & 2,268 & 2,267 & $\begin{array}{l}042 \\
202\end{array}$ & $\begin{array}{l}1,945 \\
1,862\end{array}$ & $\begin{array}{l}1,944 \\
1,865\end{array}$ & 042 & 1,938 & 1,939 \\
\hline 211 & 2,154 & 2,160 & $\begin{array}{l}240 \\
143\end{array}$ & $\begin{array}{l}1,741 \\
1,495\end{array}$ & $\begin{array}{l}1,742 \\
1,495\end{array}$ & 151 & 1,795 & 1,788 \\
\hline 222 & 1,748 & 1,748 & 223 & 1,466 & 1,467 & 222 & 1,746 & 1,748 \\
\hline 240 & 1,740 & 1,738 & $\begin{array}{l}261 \\
322\end{array}$ & $\begin{array}{l}1,353 \\
1,353\end{array}$ & $\begin{array}{l}1,350 \\
1,353\end{array}$ & 241 & 1,669 & 1,670 \\
\hline 312 & 1,387 & 1,387 & 341 & 1,315 & 1,316 & 333 & 1,165 & 1,165 \\
\hline 303 & 1,242 & 1,241 & $\begin{array}{l}063 \\
303\end{array}$ & $\begin{array}{l}1,295 \\
1,242\end{array}$ & $\begin{array}{l}1,296 \\
1,244\end{array}$ & 352 & 1,152 & 1,154 \\
\hline 244 & 1,134 & 1,134 & 244 & 1,136 & 1,137 & & & \\
\hline 334 & 1,036 & 1,036 & $\begin{array}{l}164 \\
324\end{array}$ & $\begin{array}{l}1,096 \\
1,066\end{array}$ & $\begin{array}{l}1,095 \\
1,066\end{array}$ & & & \\
\hline
\end{tabular}


Tabela 8

Parâmetros unitários extrapolados das inclusões de olivina

\begin{tabular}{cccc}
\hline Amostra & $\mathrm{a}_{0}$ & $\mathrm{~b}_{0}$ & $\mathrm{c}_{0}$ \\
1 & $4,773 \pm 0,010$ & $10,232 \pm 0,015$ & $6,013 \pm 0,010$ \\
11 & $4,750 \pm 0,007$ & $10,202 \pm 0,012$ & $5,979 \pm 0,007$ \\
13 & $4,774 \pm 0,010$ & $10,221 \pm 0,026$ & $6,005 \pm 0,008$ \\
18 & $4,755 \pm 0,005$ & $10,187 \pm 0,010$ & $5,983 \pm 0,005$ \\
34 & $4,765 \pm 0,005$ & $10,215 \pm 0,010$ & $5,999 \pm 0,006$ \\
35 & $4,756 \pm 0,007$ & $10,190 \pm 0,012$ & $5,983 \pm 0,007$ \\
\hline
\end{tabular}

No entanto, êste processo utiliza os valores de sòmente dois parâmetros unitários e, desde que os diagramas de precessão permitem a medida de $a_{0}, b_{0}$ e $c_{0}$, pode-se obter a composição química da inclusão com maior segurança, através destas três constantes.

\begin{tabular}{rrrr} 
& & Forsterita & \multicolumn{1}{c}{ Fayalita } \\
$\mathrm{a}_{0}$ & $(\stackrel{\circ}{\AA})$ & $4,756 \pm 0,005$ & $4,817 \pm 0,005$ \\
$\mathrm{~b}_{0}$ & $\left(\begin{array}{c}0 \\
\circ\end{array}\right)$ & $10,195 \pm 0,005$ & $10,477 \pm 0,005$ \\
$\mathrm{c}_{0}$ & $\left(\begin{array}{l}0 \\
\circ\end{array}\right)$ & $5,891 \pm 0,010$ & $6,105 \pm 0,010$
\end{tabular}

Assim, o parâmetro unitário da inclusão, obtido experimentalmente, colocado sôbre as curvas de variação de $\mathrm{a}_{0}, \mathrm{~b}_{0}$ e $\mathrm{c}_{0}$ da olivina, com relação à sua composição química, pode, imediatamente, localizá-la dentro da série forsterita-fayalita.

Na Figura 9 êste procedimento é efetuado para cada um dos parâmetros das seis inclusões estudadas. A composição média pode, assim, ser obtida gràficamente, pela reta mais próxima dos três segmentos determinados sôbre as curvas de variação de $a_{0}, b_{0}$ e $c_{0}$.

Dêste modo, pode-se verificar que as inclusões de olivina têm composição muito próxima do têrmo magnesiano ( $\mathrm{Ta}$ bela 9), havendo, mesmo, algumas, onde os parâmetros unitários são idênticos aos da forsterita $100 \%$ pura. Outras, têm composição variável, mas as amostras mais ricas em $\mathrm{Fe}$ podem ainda ser incluídas dentro do têrmo crisolita $\left(\mathrm{Mg}_{0,80}\right.$ $\left.\mathrm{Fe}_{0,20} \mathrm{SiO}_{4}\right)$.

A confirmação destas determinações foi realizada com a medida dos índices obtido pelos parâmetros unitários.

Tabela 9

Composição química das inclusões de olivina
A determinação, neste caso, pode ser efetuada gràficamente, conhecendo-se, "a priori", as constantes unitárias dos têrmos extremos da série isomorfa da olivina (Yoder e Sahama, 1957):

de refração de uma das inclusões (amostra 34), depois de destacada do hospedeiro. Os valores obtidos pelo método da imersão: $a=1,652, \beta=1,668 \mathrm{e}$ $\gamma=1,686$, colocados sôbre a curva de variação destas propriedades com relação à composição química da olivina (Deer et al., 1962), forenceram: $\mathrm{Mg}_{0,92}$ $\mathrm{Fe}_{0,08} \mathrm{SiO}_{4}$, o que concorda com o dado

\begin{tabular}{ccc}
\hline Amostra & $\begin{array}{c}\text { Forsterita } \\
(\%)\end{array}$ & $\begin{array}{c}\text { Fayalita } \\
(\%)\end{array}$ \\
1 & 80 & 20 \\
11 & 98 & 2 \\
13 & 85 & 15 \\
18 & 98 & 2 \\
34 & 90 & 10 \\
35 & 98 & 2 \\
\hline
\end{tabular}



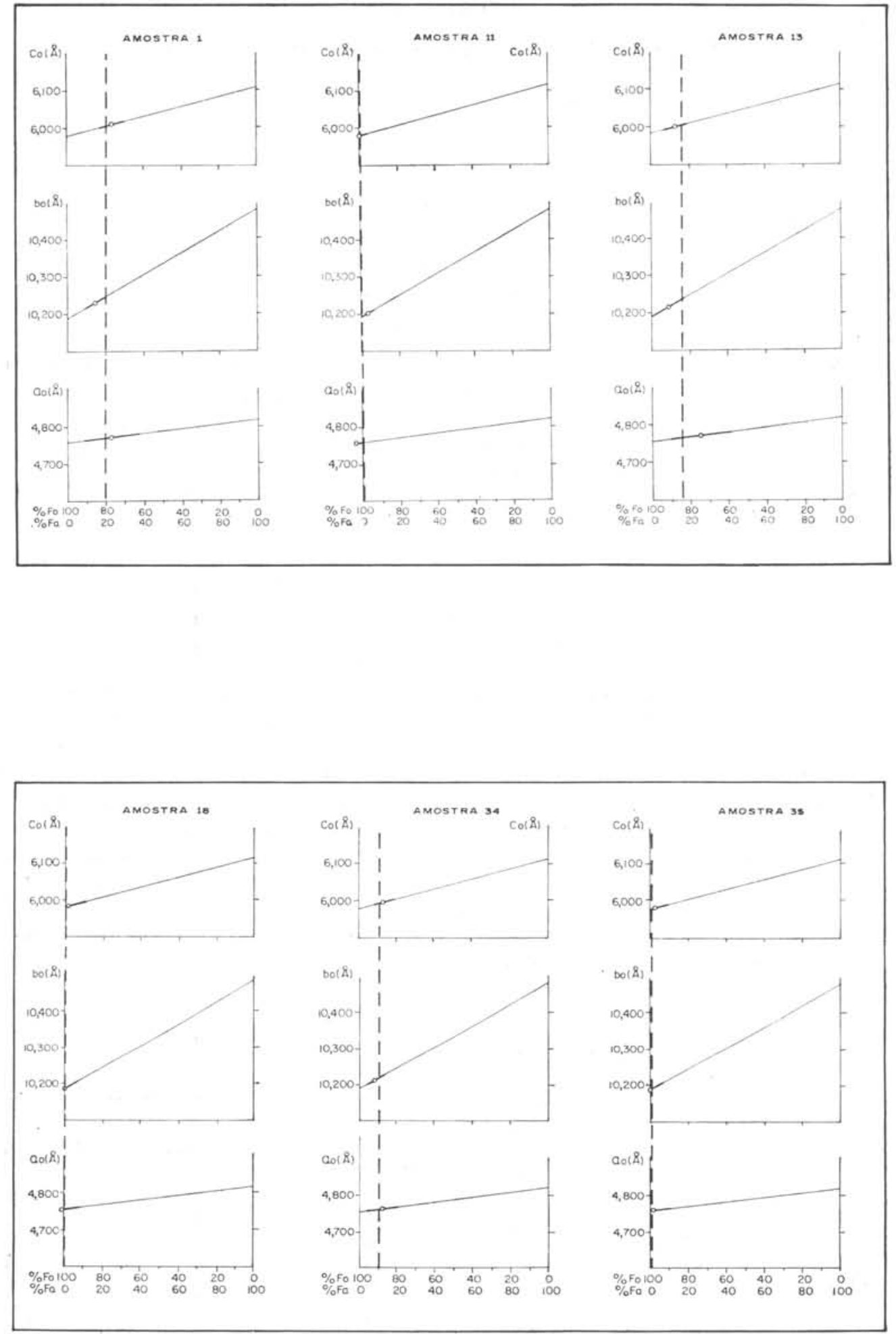

Figura 9 - Determinação gráfica da composição química das inclusőes de olivina. 


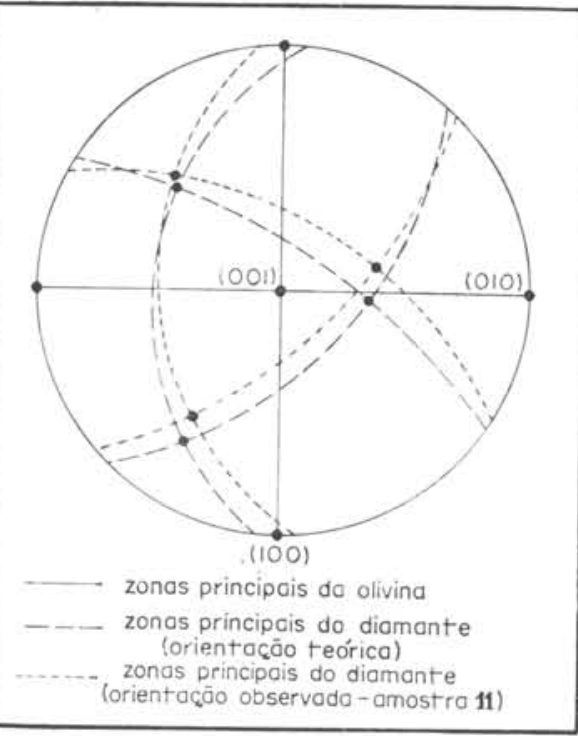

Figura 10 - Estereograma mostrando a orientação mútua da olivina e diamante (orientaçâo Giardini e Mitchell, 1953).

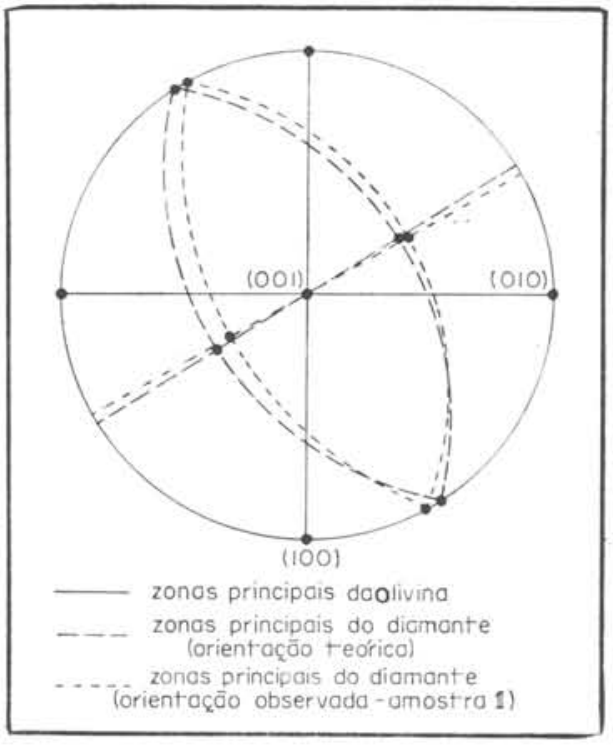

Figura 11 - Estereograma mostrando a orientação mútua da olivina e diamante (orientaçāo Harris, 1966).

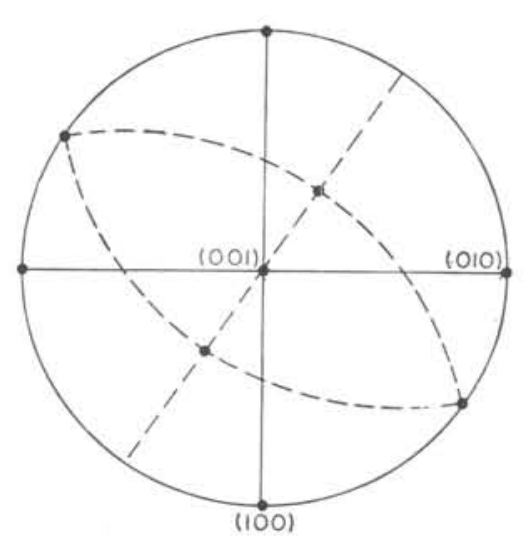

zonas principais da olivina zonas principais do diamante

Figura 12 - Estereograma mostrando a orientação mútua da olivina e diamante (orientação $\mathrm{A}$ )

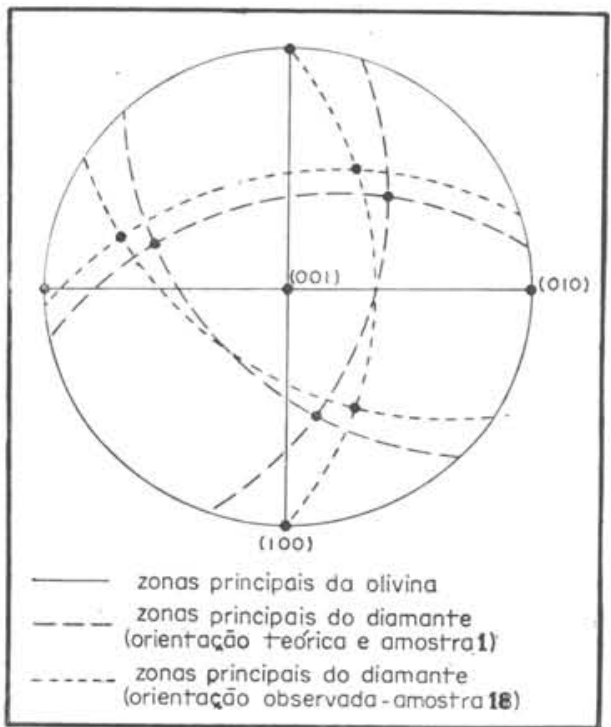

Figura 13 - Estereograma mostrando a orientação mútua da olivina e diamante (orientação B). 


\section{d. Orientação}

A orientação da olivina, no diamante, foi primeiramente observada por Giardini e Mitchell (1953), e a inclusão, bem desenvolvida e alongada na direção[110] do diamante, mostrava a coincidência do plano (010), com o plano (111) do hospedeiro. A razão deste desenvolvimento epitáxico foi interpretada por Hartman (1954), pela equivalência das translações reticulares e dos ângulos formados entre as direções onde se verificavam as coincidências das translações. Posteriormente, Harris (1966), descreveu uma nova orientação, onde o plano (010) da olivina também coincidia com o plano (111) do diamante. Porém, o ajuste dos dois retículos, no plano comum aos dois cristais, se efetuava de modo diverso ao descrito anteriormente. O crescimento epitáxico, neste caso, pode ser explicado de maneira análoga, pela equivalência de translações e dos ângulos, nas direções consideradas. Harris, no mesmo trabalho, ainda menciona a possibilidade de outras orientações epitáxicas, pela posição relativa das reflexões do diamante e da olivina, observada em diagramas de Laue. Em 1969, Camargo e Leite citaram dois outros tipos de orientações epitáxicas: orientação A, onde (100) da olivina coincide com (111) do diamante; e orientação B, onde a coincidência se efetua entre os planos (001) da inclusão e (111) do diamante.

A orientação de Giardini e Mitchell (1953), foi observada na amostra 11, onde a inclusão de olivina se desenvolve na direção [110] de um octaedro de diamante que, por sua vez, se encontra incluído por um cristal maior. A orientação mútua dos dois diamante obedece à geminação, segundo (111). O ângulo de extinção nesse cristal alongado de olivina $\left(\beta \wedge[101] \cong 35^{\circ}\right)$, juntamente com os dados obtidos dos diagramas de precessão, permitiram o reconhecimento desta epitaxia. Contudo, pode-se notar ligeiro desvio, na coincidência dos planos (111) do hospedeiro e (010) da inclusão, na projeção estereográfica, obtida dos diagramas de precessão e que mostra a orientação mútua dos dois cristais (Figura 10). Desvios de até $10^{\circ}$ da orientação epitáxica teórica, foram já notados por Harris et al. (1966).

A orientação proposta por Harris (1966), foi encontrada na inclusão alongada da amostra 1 . O ângulo de extinção com a direção de maior desenvolvimento é também aproximadamente $35^{\circ}$, e a projeção estereográfica, efetuada com base nos diagramas de precessão, revela um desvio de cerca de $8^{\circ}$ da posição de coincidência teórica (Figura 11).

Nas inclusões das amostras 13, 34 e 35 (equidimensionais ou ligeiramente alongadas), pode-se notar a coincidência dos planos (100) da olivina e (111) do diamante (orientação A), o que também se confirma em diagramas de precessão para orientação dos cristais(Prancha V a). Esta possibilidade de epitaxia foi já suspeitada por Harris (1966), por ser a mais compátivel com a orientação dos tetraedros de $\mathrm{SiO}_{4}$ da olivina, com relação aos do diamante. O desenvolvimento epitáxico é também perfeitamente justificável, pela coinciđência dos nós reticulares, em três direções não complanares (Tabela 10). A extinção, neste caso, é simétrica ou reta e, nas projeções estereográficas, a partir dos dados experimentais, podem-se também notar pequenos desvios da posição de epitaxia ideal (Figura 12).

Outra interpretação para este crescimento orientado da olivina, poderia considerar a coincidência dos planos (133) da inclusão e (111) do diamante, pois, o ângulo diedro teórico, entre os planos (100) e (133) da olivina (igual a $70^{\circ}$ para a forsterita), é muito próximo ao formado pelas faces (111) e (1ī1) do diamante.

No cristal tabular da amostra 1 e na inclusão da amostra 18 , se observa perfeito paralelismo entre as faces (001) da olivina e (111) do diamante (orientação B), o que se pode comprovar no diagrama de precessão (foto para orientação), mostrando na Prancha $\mathrm{Vb}$. O desenvolvimento orientado da inclusão pode também ser interpretado, como nos casos anteriores, pela igualdade das 
Tabela 10 - Orientação A

\begin{tabular}{lccc}
\hline & Diamante & Olivina & Desvio \\
Plano de coincidencia & $(1 \overline{1} 1)$ & $(100)$ & \\
Direção 1 & {$[011]$} & {$[001]$} & \\
Translação em 1 ( $\left.{ }_{\AA}\right)$ & $17,64(7 \mathrm{~T}[011])$ & $17,97(3 \mathrm{~T}[001])$ & $1,8 \%$ \\
Direção 2 & {$[21 \overline{1}]$} & {$[010]$} & \\
Translação em 2( $\left.{ }_{\AA}^{\circ}\right)$ & $30,59(7 \mathrm{~T}[21 \overline{1}])$ & $30,60(3 \mathrm{~T}[010])$ & $0,3 \%$ \\
Angulo entre 1 e 2 & $90^{\circ}$ & $90^{\circ}$ & \\
Direção 3 & {$[1 \overline{1} 1]$} & {$[100]$} & \\
Translação em 3( $\left.{ }_{\AA}^{\circ}\right)$ & $18,54(3 \mathrm{~T}[1 \overline{1} 1])$ & $19,04(4 \mathrm{~T}[100])$ & $2,7 \%$ \\
\hline
\end{tabular}

translações e dos ângulos, no plano comum aos dois cristais (Tabela 11). A projeção estereográfica, possível através dos diagramas de precessão, revela o desvio de alguns graus da posição teórica de coincidência, no caso da amostra 18 (Figura 13).

Nos outros exemplares, contendo inclusões de olivina, estes cristais parecem, também, estar orientados, segundo um dos tipos acima descritos, o que se conclui pela sua morfologia e ângulos de extinção.

\section{Granada}

As inclusões de granada são encontradas raramente, nos diamantes do Triângulo Mineiro. No total das amos- tras estudadas, observaram-se sòmente três exemplares que apresentavam inclusões deste tipo: amostra 36 (Rio Douradinho); amostra 38 (sem procedência segura) e amostra 39 (Rio Indaiá).

Apesar de monorrefringentes, estas inclusões são dificilmente identificadas apenas por via óptica, pois tal caráter é mascarado pela birrefringência anômala do hospedeiro. No entanto, alguns cristais (amostras 38 e 39), podem apresentar coloração entre rosa e vermelho, o que talvez seja suficiente para distinguir a granada das demais inclusões presentes no diamante, considerando que tais tonalidades são mais comuns nas granadas (Harris, 1968). A outra inclusão (amostra 36), quando observada

Tabela 11 - Orientação B (olivina tabular)

\begin{tabular}{lccc}
\hline & Diamante & Olivina & Desvio \\
Plano de coincidência & $(111)$ & $(001)$ & \\
Direção 1 & {$[0 \overline{1} 1]$} & {$[1 \overline{2} 0]$} & \\
Translação em 1( $\left.{ }_{\AA}^{\circ}\right)$ & $20,16(8 \mathrm{~T}[0 \overline{1} 1])$ & $20,95(1 \mathrm{~T}[1 \overline{2} 0])$ & $3,9 \%$ \\
Direção 2 & {$[1 \overline{2} 1]$} & {$[2 \overline{1} 0]$} & \\
Translação em 2( $\stackrel{\circ}{\circ})$ & $13,11(3 \mathrm{~T}[1 \overline{2} 1])$ & $13,95(1 \mathrm{~T}[2 \overline{1} 0])$ & $6,4 \%$ \\
Ângulo entre 1 e 2 & $30^{\circ} 00^{\prime}$ & $29^{\circ} 53^{\prime}$ & \\
Direção 3 & {$[111]$} & {$[001]$} & $3,2 \%$ \\
Translação em 3( $\stackrel{\circ}{\circ})$ & $6,18(1 \mathrm{~T}[111])$ & $5,99(1 \mathrm{~T}[001])$ & \\
\hline
\end{tabular}


Tabela 12 - Distâncias interplanares das inclusões de granada

\begin{tabular}{|c|c|c|c|c|c|c|c|c|}
\hline & ostra & & & ostra & & & ostra & \\
\hline & $\left(\begin{array}{l}\circ \\
\AA\end{array}\right)$ & & & $\left(\begin{array}{l}0 \\
\mathrm{~A}\end{array}\right)$ & & & $\left(\begin{array}{l}\AA \\
\AA\end{array}\right)$ & \\
\hline hk $\ell$ & obs & calc & hk $\ell$ & obs & calc & hk $\ell$ & obs & calc \\
\hline 420 & 2,606 & 2,606 & 220 & 4,080 & 4,078 & 420 & 2,578 & 2,574 \\
\hline 521 & 2,125 & 2,127 & 420 & 2582 & 2579 & 521 & 2,099 & 2,102 \\
\hline 440 & 2,059 & 2,059 & & & & 440 & 2,037 & 2,034 \\
\hline 444 & 1,681 & 1,681 & 642 & 1,540 & 1,541 & 444 & 1,658 & 1,662 \\
\hline 642 & 1,557 & 1,556 & 840 & 1,290 & 1,289 & 642 & 1,539 & 1,538 \\
\hline 741 & 1,432 & 1.434 & & & & 732 & 1,463 & 1,462 \\
\hline 840 & 1303 & & 842 & 1,258 & 1,258 & 840 & 1,288 & 1,287 \\
\hline 842 & 1,500 & 1, & 864 & 1,070 & 1.071 & 941 & 1,163 & 1,163 \\
\hline 941 & 1,212 & 1,211 & 10 & 1053 & & $\begin{array}{r}10.42 \\
864\end{array}$ & $\begin{array}{l}1,050 \\
1.069\end{array}$ & 1,051 \\
\hline 10.42 & $1,1 / 6$ & 1,176 & 0.42 & & 1,053 & 880 & 1,019 & $\begin{array}{l}1,009 \\
1,017\end{array}$ \\
\hline 880 & 1,063 & 1,963 & 880 & 1,020 & 1,019 & 12.60 & 0,857 & 0,858 \\
\hline & 1,029 & 1,029 & & & & 888 & 0,830 & 0,831 \\
\hline
\end{tabular}

no interior do hospedeiro, apresentavase incolor, sugerindo, à primeira vista, tratar-se de olivina: suspeita reforçada pelo hábito sub-idiomórfico e alongado. Depois de destacada do diamante, foi possível, no entanto, observar a coloração amarela-alaranjada, com reflexos dourados, semelhante à descrita por Futergendler (1958) e Orlof (1959), em granadas de diamantes russos.

$\mathrm{O}$ hábito nos outros cristais de granada, é também sub-idiomórfico e alongado, podendo-se notar, ainda, o arredondamento de algumas arestas. A forma rombododecaédrica, mais desenvolvida na direção [001], e apresentando faces planas, lisas ou estriadas, pode ser notada na granada incluída na amostra 36 (Prancha IIIh). A generalização destas observações é, no entanto insegura, em virtude do pequeno número de amostras estudadas.

Os parâmetros unitários das três inclusões foram determinados em diagramas de precessão, como no caso das olivinas. As distâncias interplanares obtidas (Tabela 12) possibilitaram o cálculo dos $a_{1}$, que foram posteriormente extrapolados pelo mótodo gráfico-analítico (Tabela 13) Os $\mathrm{d}_{\mathrm{hk \ell}}$ teóricos, calculados a partir destas constantes, são mostrados na Tabela 12, ao lado dos valores observados.

$\mathrm{Na}$ série isomorfa das granadas, sòmente a determinação do parâmetro unitário a não é suficiente para a sua perfeita identificação, visto que se pode

Tabela 13 - Parâmetros unitários extra polados e índices de refração das inclusões de granada

\begin{tabular}{|c|c|c|}
\hline Amostra & $a_{o}$ & $n$ \\
\hline 36 & $11,647 \pm 0,012$ & 1,78 \\
\hline 38 & $11,533 \pm 0,012$ & 1,76 \\
\hline 39 & $11,511 \pm 0,015$ & - \\
\hline
\end{tabular}


Tabela 14 - Composição químicas das inclusões de granada

\begin{tabular}{cccccc}
\hline & $\%$ & $\%$ & $\%$ & $\%$ & $\%$ \\
Amostra & Andradita & Almandina & Piropo & Espessarita & Grossulária \\
& - & 10 & 50 & 40 & - \\
36 & - & 38 & 51 & - & 11 \\
& 9 & 25 & 66 & - & - \\
38 & 32 & 11 & 57 & - & 11 \\
& 26 & - & 63 & - & 40 \\
\hline
\end{tabular}

considerar a existência de cinco têrmos principais, mais freqüentes (Deer et al., 1962): almandina, andradita, grossulária, piropo e espessartita, o que torna necessária, também, para isto, a medida da densidade e índice de refração. Tratando-se, no entanto, de cristais diminutos $(0,3 \mathrm{~mm}$ no máximo), a determinação da densidade é difícil e, deste modo, a composição química das inclusões não pôde ser perfeitamente estabelecida.

Os valores de a, juntamente com os índices de refração, medidos nas amostras 36 e 38 (Tabela 13), possibilitaram no entanto, estimar a composição química dessas inclusões, com relação a três componentes, entre as cinco principais da série das granadas. Utilizou-se, para isto, o método gráfico, introduzido por Sriramadas (1957), partindo-se do prin- cípio que a maioria das granadas (cêrca de $65 \%$ ), podem ser expressas com relação a apenas três das componentes acima citadas. Os resultados assim obtidos, mostram diversas composições químicas compativeis com as constantes utilizadas na sua determinação. Verifica-se, entretanto (Tabela 14), que quase tôdas as interpretações possíveis indicam a predominância do têrmo magnesiano (piropo), seguindo-lhe, em ordem decrescente, as componentes ricas em $\mathrm{Fe}$ (almandina) e Ca (andradita). O diamante 39 foi preservado para estudos futuros e, por esta razão, não se determinou o índice de refração da granada nele incluída. $O$ parâmetro unitário dêste cristal ( $\mathrm{a}_{\mathrm{o}}=$ $11,511 \AA$ ), indica, no entanto, a predominância das componentes ferro-magne-

Tabela 15 - Orientação A (amostra 39)

\begin{tabular}{|c|c|c|c|}
\hline & Diamante & Granada & Desvio \\
\hline Plano de coincidência & $(001)$ & $(011)$ & \\
\hline Direção 1 & {$[1 \overline{1} 0]$} & {$[2 \overline{1} 1]$} & \\
\hline Translação em 1 ( & $55,44(11 . \mathrm{T}[0 \overrightarrow{1} 1])$ & $56,82(2 . \mathrm{T}[2 \overline{1} 1])$ & $2,5 \%$ \\
\hline Direção 2 & {$[110]$} & {$[11 \overline{1}]$} & \\
\hline Translação em $2\left(\begin{array}{l}\AA \\
\AA\end{array}\right)$ & $20,16(4 . \mathrm{T}[110])$ & $20,09\left(1 . \mathrm{T}_{[11 \overline{1}]}\right)$ & $0,4 \%$ \\
\hline Ângulo entre 1 e 2 & $90^{\circ}$ & $90^{\circ}$ & \\
\hline Direção 3 & [001] & [011] & \\
\hline Translação em $3(\stackrel{\circ}{\AA})$ & $32,19(9 . \mathrm{T}[001])$ & $32,80(2 . \mathrm{T}[011])$ & $2,0 \%$ \\
\hline
\end{tabular}




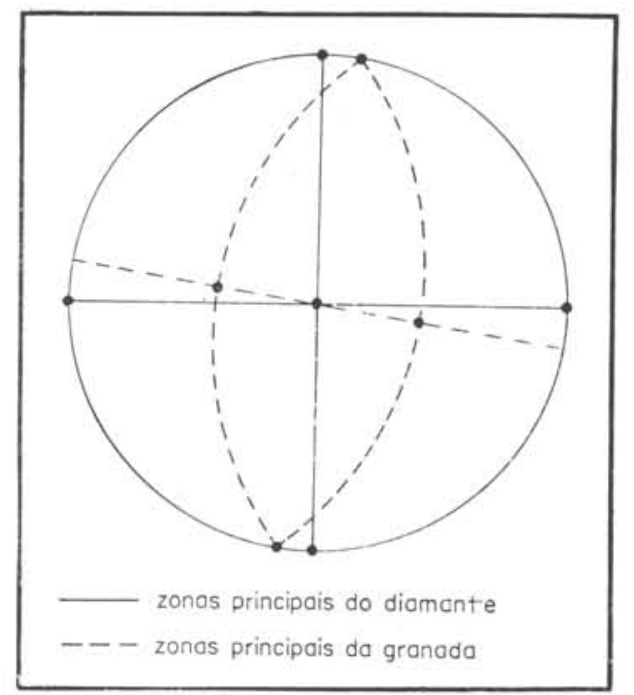

Figura 14 - Estereograma mostrando a orientação mútua da granada e diamante, amostra 39 (orientaçāo A).

sianas cujos parâmetros variam de 11,46

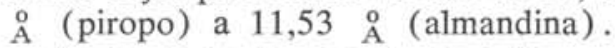

A orientação de granadas incluídas em diamantes já foi observada por Futergendler e Kamenetskii (1961), por meio de difração de raios $\mathrm{X}$. Neste caso, verificou-se sòmente a coincidência das direções [100] do diamante e [100] da inclusão, pois $\mathrm{T}_{[100]}$ da granada $(=\mathrm{a}$

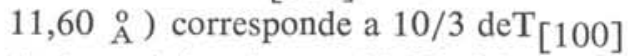
do hospedeiro (= a $11,89 \AA \AA$ ), sendo o desvio igual a $2,5 \%$. O paralelismo entre os planos (111) do diamante e (110) da granada foi também notado por Eppler (1961), através da microscopia óptica. A equivalência de translações é também possível: $\mathrm{T}$ [110] da granada ( = a $16,40 \AA$ ̊), equivalente a $8 / 3$ de $\mathrm{T}$ [111] do diamante $(=$ $16,48 \AA$ ̊ ), com discordância de apenas $0,5 \%$.

As granadas incluídas nos diamantes do Triângulo Mineiro, parecem também estar orientadas. Contudo, o número reduzido de amostras estudadas torna inseguro tomar como gerais os tipos de orientação observados .

No diagrama de precessão mostrado na Prancha V c (Amostra 39), pode-se notar o perfeito paralelismo entre as zo-

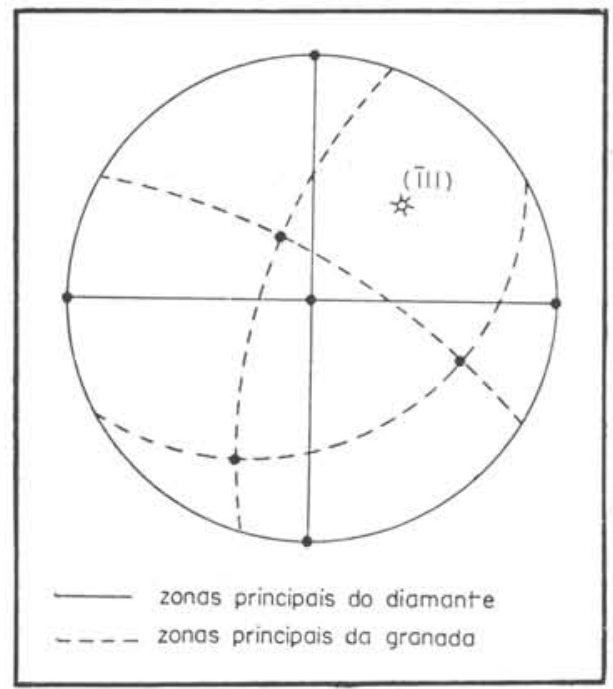

Figura 15 - Estereograma mostrando a orientação mútua da granada e diamante(orientação B)

nas $[1 \overline{1} 0]$ do diamante e $[2 \overline{1} 1]$ da granada e, nesta zona, observa-se, ainda, a proximidade dos planos (001) do hospedeiro e (011) da inclusão. Estes dados, colocados em projeção estereográfica (Figura 14), mostram, de outro lado, a coincidência da direção [111] da granada e [110] do diamante, sendo o desvio, de aproximadamente $5^{\circ}$.

A equivalência das translações, ao longo destes eixos é também verificada(Tabela 15 e tal interpretação é muito próxima (desvio de $10^{\circ}$ ) da orientação observada por Futergendler e Kamenetskii (1961).

Uma outra orientação possível, para as inclusões de granada, pode ser comprovada pelo diagrama de precessão da amostra 36 (Prancha $V_{\alpha}$, onde se observa a coincidência das direções [112] do hospedeiro e [121] da inclusão. Os dados obtidos neste diagrama podem fornecer duas interpretações possíveis, para a orientação mútua dos dois cristais. Numa delas (Figura 15), pode-se observar a coincidência dos planos (111) do diamante e (111) da inclusão, o que também se verifica no diagrama de precessão da amostra 38 (Prancha Ve). A partir dêste diagrama, a orientação mútua dos dois cristais pode, igualmente, ser interpretada de duas maneiras e uma 


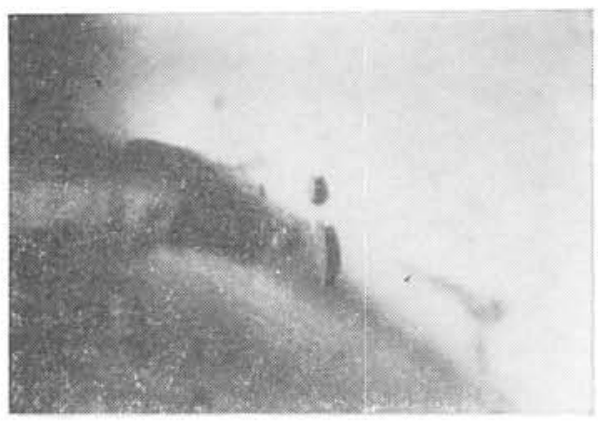

a

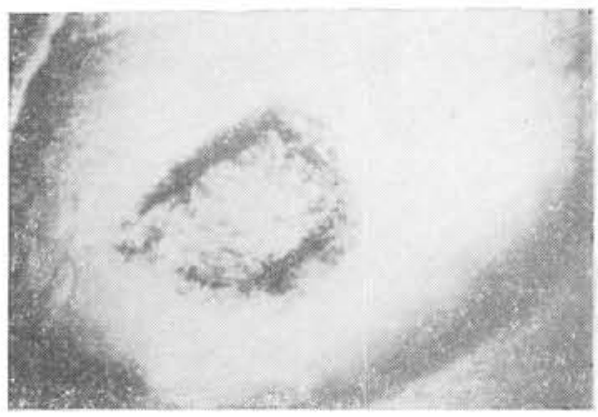

C

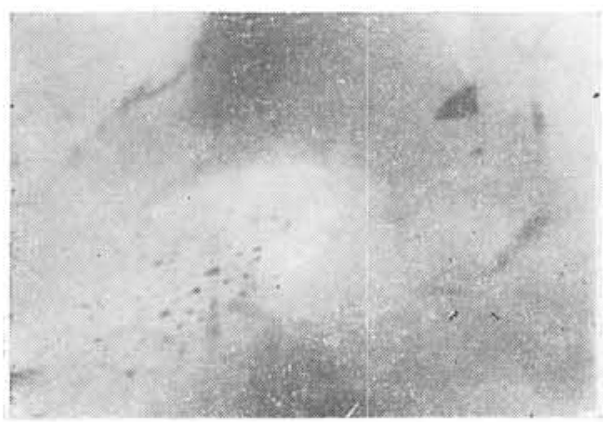

e

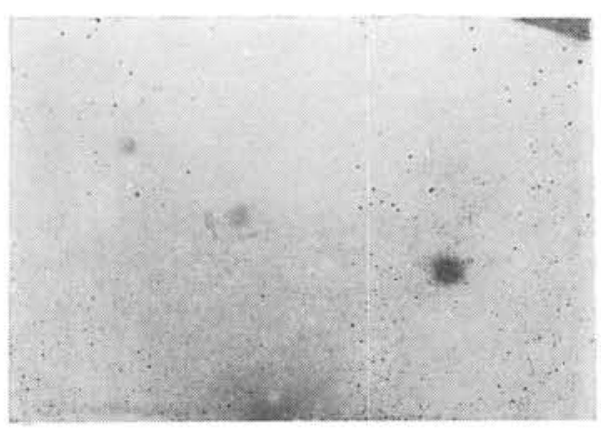

q

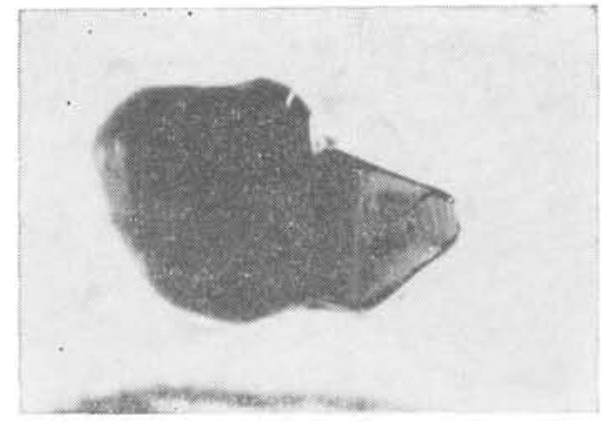

b

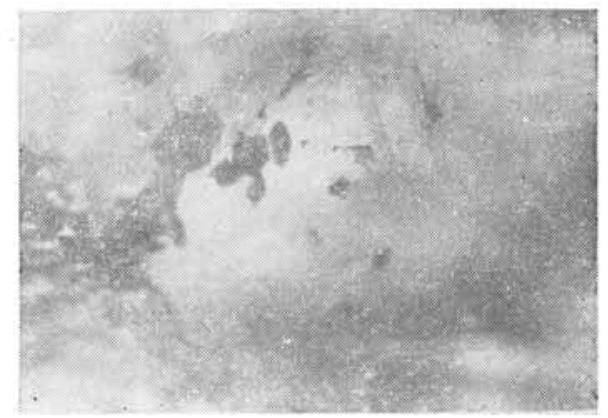

d

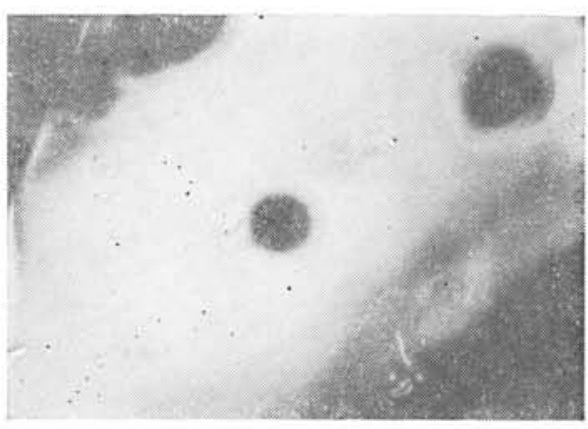

f

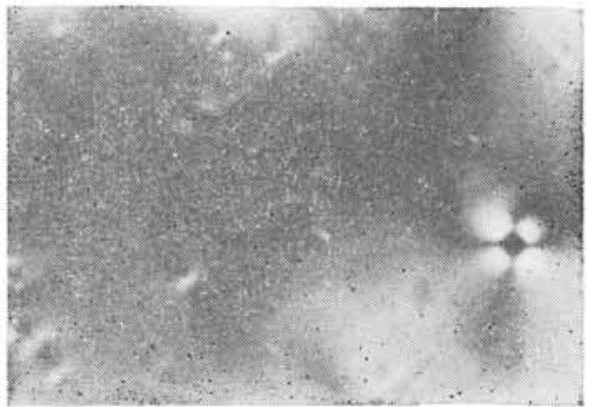

h

Prancha IV - a. Inclusōes de cromita (x 75); b. Inclusão de cromita (octaedro tabular) (x 60); c. Inclusāo de diamante parcialmente recoberto $(x 40)$; $d$. Inclusões negras irregulares $(x 50)$; e. Inclusōes negras de contôrno triangular ( 150$)$; $\mathrm{f}$. "Pintas" associadas a microdiscos (x 100); g. "Pintas" verde-azuladas (nicóis paralelos) $(\times 50)$; h. Idem, nicóis cruzados.. 


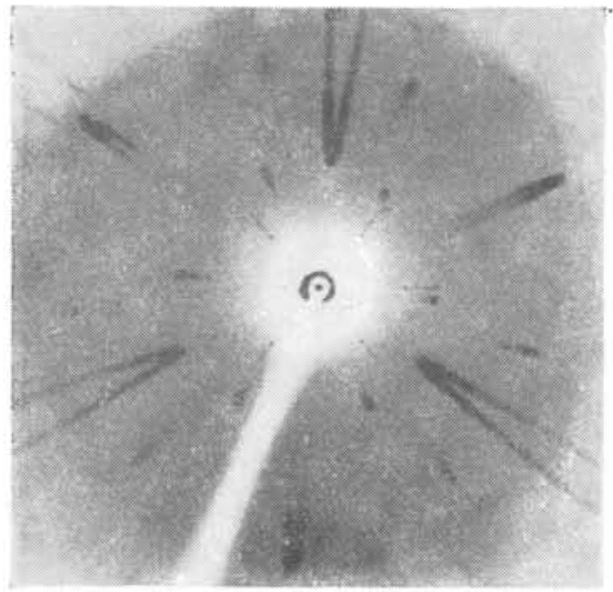

a

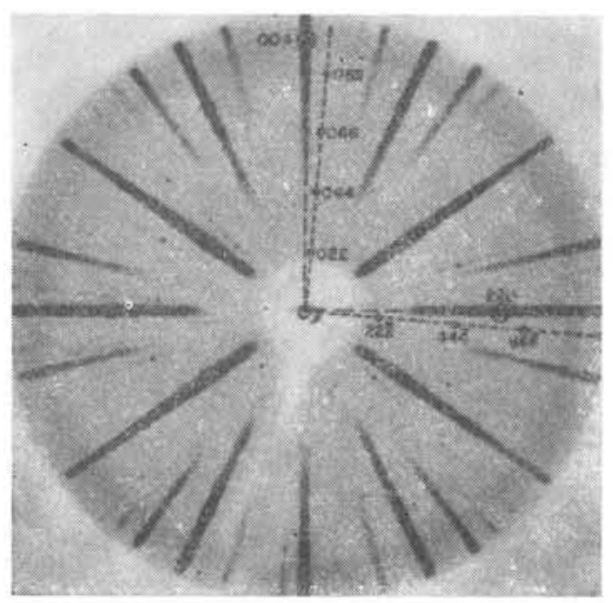

$\mathrm{C}$

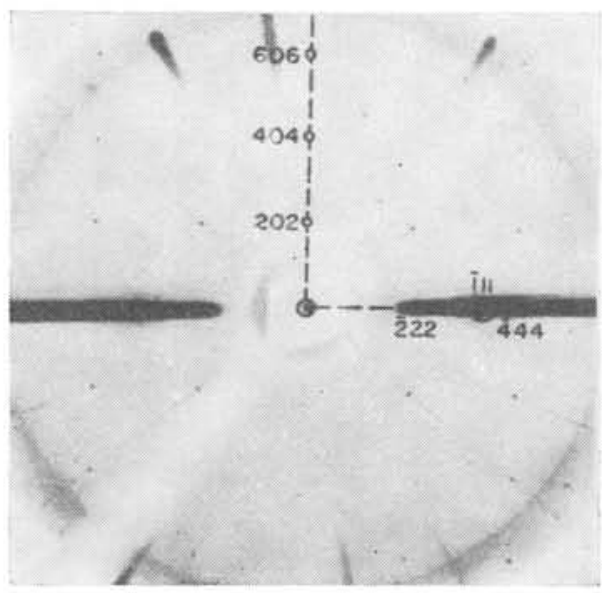

e

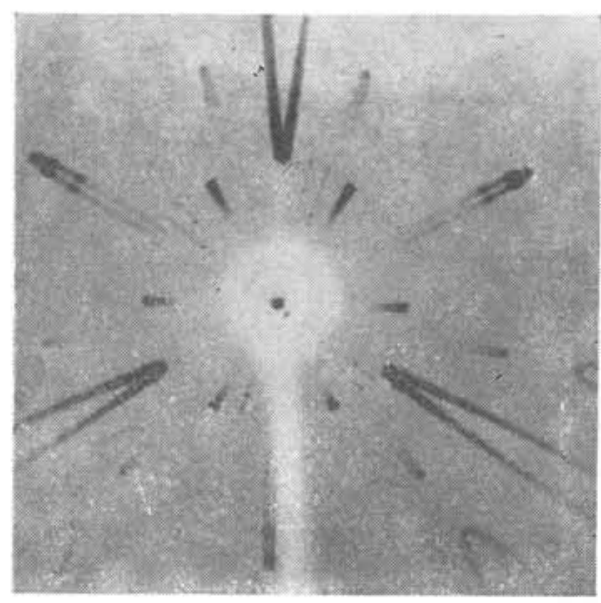

b

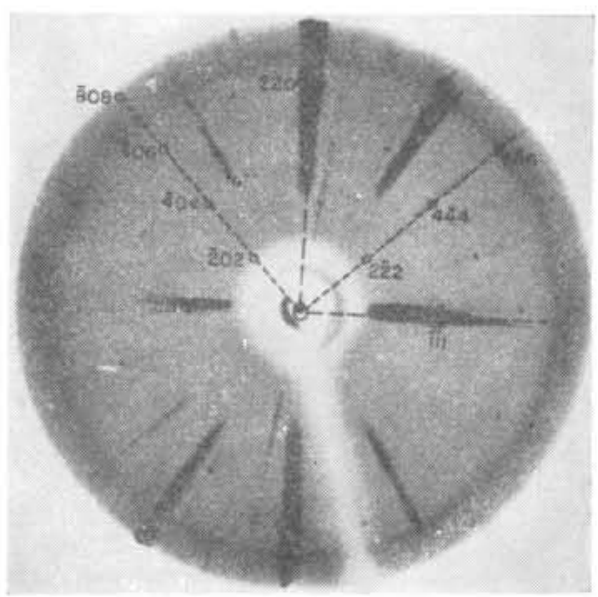

d

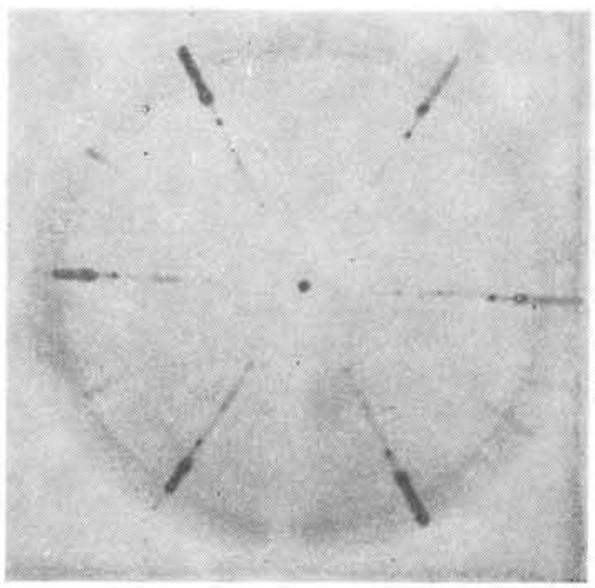

f

Prancha V - a. Diagrama de precessão mostrando a orientação da olivina (orientação A); b. Idem, orientação B); c. Diagrama de precessão mostrando a orientação da granada (orientação A); d. Idem, amostra 36 (orientação B); e. Ibidem, amostra 38 (orientação B); f. Diagrama de precessão mostrando a isorientaçâo da cromita e diamante. 
Tabela 16 - Orientação B (amostras 36 e 38)

\begin{tabular}{|c|c|c|c|}
\hline & Diamante & Granada & Desvio \\
\hline Plano de coincidência & $(\overline{1} 11)$ & $(\overline{1} 11)$ & \\
\hline Direção 1 & {$[0 \overline{1} 1]$} & {$[1 \overline{1} 2]$} & \\
\hline Translação em 1( $\left(\begin{array}{c}\AA \\
\text { ) }\end{array}\right.$ & $55,44(11 . \mathrm{T}[0 \overline{1} 1])$ & $56,82\left(2 . T_{[1 \overline{1} 2]}\right)$ & $2,5 \%$ \\
\hline Direção 2 & {$[101]$} & {$[211]$} & \\
\hline Translação em 1( $\stackrel{\circ}{\AA})$ & $55,44\left(11 . \mathrm{T}_{[101]}\right)$ & $56,82(2 . \mathrm{T}[211])$ & $2,5 \%$ \\
\hline Direção 3 & [ $\overline{1} 11]$ & {$[\overline{1} 11]$} & \\
\hline Translação em 3( $\AA$ ) & $61,80(10 . T[\overline{1} 11])$ & $60,27(3 . T[\overline{1} 11])$ & $2,4 \%$ \\
\hline
\end{tabular}

delas coincide com uma das interpretações do diagrama da amostra 36 . Neste caso, a epitaxia da granada, com relação ao diamante, pode também ser explicada pela equivalência das translações reticulares (Tabela 16).

\section{Cromita}

As inclusões de cromita (cromoespinélio), quando observadas ao microscópio, apresentam hábitos e colorações variáveis. Quando transparentes, é possível observar a côr de café, que se torna ne-

Tabela 17 - Distâncias interplanares das inclusões de cromita

\begin{tabular}{|c|c|c|c|c|c|c|c|c|}
\hline \multirow[b]{3}{*}{ hk $\ell$} & \multicolumn{2}{|c|}{ Amostra 2} & \multicolumn{2}{|c|}{ Amostra 6} & \multicolumn{2}{|c|}{ Amostra 8} & \multicolumn{2}{|c|}{ Amostra 33} \\
\hline & $\mathrm{d}_{\mathrm{hk}}$ & $\left(\begin{array}{c}\circ \\
\mathrm{A}\end{array}\right)$ & $\mathrm{d}_{\mathrm{hk}}$ & $\left(\begin{array}{l}\circ \\
\AA\end{array}\right)$ & $\mathrm{d}_{\mathrm{hk}}$ & $(\AA)$ & $\mathrm{d}_{\mathrm{hk}}$ & $\left(\begin{array}{l}\circ \\
\AA\end{array}\right)$ \\
\hline & obs & calc & obs & calc & obs & calc & obs & calc \\
\hline 111 & 4,780 & 4,794 & & & & & 4,791 & 4,794 \\
\hline 220 & 2,932 & 2,936 & 2,941 & 2,942 & 2,951 & 2,954 & 2,931 & 2,940 \\
\hline 311 & 2,505 & 2,503 & 2,508 & 2,508 & 2,513 & 2,518 & 2,501 & 2,506 \\
\hline 222 & & & & & 2,409 & 2,411 & 2,396 & 2,400 \\
\hline 400 & 2,075 & 2,076 & & & 2,088 & 2,088 & & \\
\hline 333 & & & & & 1,608 & 1,608 & 1,597 & 1,600 \\
\hline 511 & 1,597 & 1,598 & & & & & & \\
\hline 440 & & & 1,470 & 1,471 & 1,476 & 1,477 & 1,467 & 1,470 \\
\hline 531 & & & & & & & 1,403 & 1,405 \\
\hline 533 & 1,266 & 1,266 & & & & & & \\
\hline 622 & & & & & & & 1,252 & 1,253 \\
\hline 444 & & & & & 1,206 & 1,206 & 1,199 & 1,200 \\
\hline 642 & & & & & & & 1,110 & 1,111 \\
\hline 553 & & & & & 1,088 & 1,087 & & \\
\hline 731 & & & & & & & 1,082 & 1,082 \\
\hline 800 & 1,040 & 1,038 & & & & & & \\
\hline 662 & & & & & 0,958 & 0,958 & & \\
\hline 840 & & & & & 0,932 & 0,934 & & \\
\hline 844 & 0,848 & 0,848 & & & & & & \\
\hline
\end{tabular}


gra nas variedades opacas. O hábito é geralmente irregular e, neste caso, os cristais parecem ser arredondados, assemelhando-se a pequenos seixos rolados incluídos pelo hospedeiro (Prancha IVa) Cristais apresentando formas geométricas definidas são também encontrados, sendo hábito octaédrico, tabular segundo (111), e de contôrno hexagonal (Prancha IV b).

Nos diamantes do lote estudado, observaram-se apenas seis exemplares contendo inclusões dêste tipo, entre os quais quatro foram selecionados para o exame aos raios X: amostra 2 (Rio Indaiá); amostra 6 (sem procedência segura); amostra 8 (Rio Indaiá) e amostra 33 (Rio Paranaíba).

Os diagramas de precessão destes cristais forneceram as distâncias interplanares da Tabela 17, mostradas ao lado dos valores teóricos, calculados a partir dos parâmetros unitários extrapolados pelo método gráfico-analítico (Tabela 18).

Tabela 18 - Parâmetros unitários extrapolados das inclusões de cromita

\begin{tabular}{cl} 
Amostra & \multicolumn{1}{c}{$\mathrm{a}_{0}$} \\
2 & $8,304 \pm 0,005$ \\
6 & $8,32 \pm 0,01$ \\
8 & $8,353 \pm 0,005$ \\
33 & $8,313 \pm 0,005$
\end{tabular}

Estes parâmetros, juntamente com os dados ópticos, indicam que as inclusões devem apresentar composição química próxima do têrmo magnesiano, na série isomorfa da cromita (magnesiocromita). Contudo, o $\mathrm{a}_{0}$ destas inclusões, em geral inferior ao da magnesiocromita pura $\left(\mathrm{a}_{0}=8,334 \stackrel{\circ}{\mathrm{A}}\right)$, pode sugerir uma possível substituição parcial do $\mathrm{Cr}$ pelo $\mathrm{Al}$. Neste caso, uma interpretação mais segura poderia considerar as inclusões como simples cromoespinélios.

A orientação da cromita, em diamante, já foi observada em diagramas de raios $\mathrm{X}$, mostrando a isorientação dos dois cristais (Futergendler e Frank-Kamenetskii, 1961) e o desenvolvimento epitáxico obedecendo a estas condições, foi também verificado, em amostras do Triângulo Mineiro (Prancha Vf) A epitaxia, neste caso, pode igualmente ser explicada pela equivalência das translações reticulares: $T_{[100]}$ da cromita

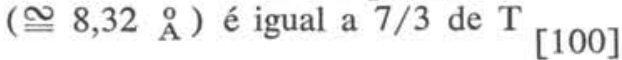
do diamante $(=8,33 \stackrel{\circ}{\AA})$.

Uma outra orientação, ainda não citada anteriormente, e encontrada em apenas um exemplar (amostra 33), é semelhante à descrita para as inclusões de granada (amostras 36 e 38). A projeção estereográfica, possível através dos dados de precessão, mostra o paralelismo entre os planos (111) dos dois cristais. A igualdade de translações, neste plano, e as direções coincidentes constam na Tabela 19 .

Tabela 19 - Orientação da cromita (amostra 33)

\begin{tabular}{|c|c|c|c|}
\hline & Diamante & Cromita & Desvio \\
\hline Plano de coincidência & (i11) & $(\overline{1} 11)$ & \\
\hline Direção 1 & {$[0 \overline{1} 1]$} & {$[1 \overline{1} 2]$} & \\
\hline Translação em 1 ( $\stackrel{0}{\AA})$ & $20,16(4 . \mathrm{T}[0 \overline{1} 1])$ & $20,33(1 . T[1 \overline{1} 2])$ & $0,9 \%$ \\
\hline Direção 2 & [101] & [211] & \\
\hline Translação em 2 ( $\stackrel{\circ}{\AA})$ & $20,16(4 . \mathrm{T}[101])$ & $20,33(1 . T[211])$ & $0,9 \%$ \\
\hline Direção 3 & [ī11] & [ī11] & \\
\hline Translação em 3 & ) $43,26(7 . T[\overline{1} 11])$ & $43,14(3 . \mathrm{T}[\overline{1} 11])$ & $0,3 \%$ \\
\hline
\end{tabular}




\section{Pentlandita}

A pentlandita foi identificada em sòmente uma amostra verde-azulada, sem procedência segura (amostra 15), que, quando observada ao microscópio, apresentava apenas inclusões negras, sendo, algumas, de contôrno triangular. Estas inclusões ocorrem, também, em muitos diamantes que, quando submetidos à difração de raios X, não apresentam inclusões heterogêneas. As irregularidades, na superfície do hospedeiro, impossibilitaram maiores informações e, considerando-se ainda, a pequena intensidade das manchas de difração da pentlandita, observada nos diagramas de raios $\mathrm{X}$, pode-se concluir que se tratam de cristais pouco desenvolvidos, o que talvez tenha impedido a sua observação direta ao microscópio.

O parâmetro $\mathrm{a}_{0}=10,08 \AA \AA$ desta inclusão, foi obtido pela média dos valôres calculados a partir das distâncias interplanares, determinadas sôbre diagramas de precessão, onde também se observa o desenvolvimento isorientado dos dois cristais. Esta epitaxia é possível, pois $T_{[100]}$ da pentlandita ( $\cong 10,80$ $\AA$ ) equivale a $3 . T$

te $(=10,71 \AA$ ̊ $)$, com discordância da ordem de $0,9 \%$.

\section{Diamante}

As inclusões de diamante não devem ser consideradas como inclusões pròpriamente ditas, pois o que ocorre na realidade é um simples zoneamento ou geminação, durante a cristalização. No caso de geminação, pelo maior desenvolvimento de um dos indivíduos, um passa a englobar o outro. Cristais de diamante, incluídos no próprio diamante, são visíveis sòmente quando ambos os indivíduos apresentam colorações diferentes, o que não se observou nos diamantes do Triângulo; ou quando o diamante incluído se apresenta recoberto por inclusões negras (Prancha IV c). No entanto, mesmo assim, é dificil a observação do cristal incluído, pois, geralmente, a recobertura é apenas parcial. Quando o capeamento envolve totalmente a inclusão, esta pode ser fàcilmente confundida com outras inclusões opacas (cromita ou magnetita). Algumas vezes, a presença do cristal incluído é verificada sòmente sob a lâmpada de quarto, quando se pode notar a fluorescência da inclusão, no interior do hospedeiro não fluorescente.

As inclusões de diamante se orientam em relação ao hospedeiro e, neste caso, o desenvolvimento é paralelo ou obedece à geminação, segundo (111). Em nenhum dos casos estudados, as inclusões são dispostas ao acaso.

\section{Inclusões não identificadas}

Durante os trabalhos de identificação de inclusões em diamantes do Triângulo Mineiro, a maioria dos cristais estudados não revelou, sob os raios $\mathrm{X}$, a presença de inclusões heterogêneas. Quando observados ao microscópio, êstes exemplares mostravam, no entanto, inclusôes negras, com reflexos metálicos e formas variáveis, mas geralmente aciculares, placóides ou irregulares (Prancha IV d). As inclusões placóides sempre se orientam paralelamente ao plano (111) do hospedeiro e podem desenvolver formas geométricas definidas, apresentando contôrno triangular ou hexagonal (Prancha IV e ). A orientação é, também, verificada nas inclusões aciculares e, neste caso, ocorrem alongadas, segundo [110] do diamante. As inclusões irregulares lembram fendas ou fraturas de tensão e, algumas vêzes ,formam-se pelo agrupamento de pequenas inclusões placóides ou aciculares, que podem-se distribuir paralelamente a (111) do hospedeiro. Êste último tipo de inclusão é comum em cristais que apresentam a associação das formas simples $\langle 111\rangle,\langle 110\rangle$ e $\langle 100\rangle$, vulgarmente denominados 'cascudos'.

A análise química de uma destas inclusões (placóide e de contôrno irregular), obtida na microssonda da Castaing (electron microprobe), revelou sòmente a presença de carbono, podendo-se concluir, disto, que devem ser de grafita, já verificada por Harris (1968), ou devem resultar simplesmente de defeitos 
cristalinos, originados durante o crescimento do cristal de diamante. Esta última suposição talvez mais viável pode ser comprovada não só pela ausência das reflexões características da grafita, em 16 amostras estudadas por difração de raios $\mathrm{X}$, como pela ocorrência freqüente destas inclusões negras, ao longo da superfície de contacto de geminados, fato iá notado por Slawson (1950). Estes defeitos talvez pudessem ser interpretados como gratifização parcial, o que foi admitido por Friedel (1932), para as variedades negras de diamante. Neste caso, seria possível registrar-se a presença de grafita, em diagramas de raios X, desde que esta ocorra em cristais relativamente desenvolvidos.

Outras inclusões não identificadas, porém menos freqüentes que as primeiras, parecem também tratar-se de material homogêneo. São pequenas "pintas" esféricas (Prancha IV g), situadas próximo da superfície do hospedeiro, com diâmetro máximo de $0,1 \mathrm{~mm}$, coloração verde-azulada ou castanho-avermelhada e bordos indistintos, o que talvez indique a continuidade do meio óptico. Estas "pintas", principalmente as de côr verde-azul, provocam forte birrefringência, bem caracterizada, no diamante circundante (Prancha IV h ). Em geral, ocorrem isoladas, mas podem agrupar-se, chegando a recobrir, parcial ou totalmente, o hospedeiro.

Os exemplares que apresentam êste tipo de inclusão, quando submetidos à difração de raios $\mathrm{X}$, mostram sòmente a presença das reflexões do diamante, razão pela qual estas "pintas" devem constituir apenas regiões do diamante sob a influência de tensões, talvez originadas pela presença de impurezas. A análise química de elementos menores, em diamantes que apresentam estas inclusões verde-azuladas, revela, de fato, teores anômalos de $\mathrm{Fe}$ e $\mathrm{Si}$ (Gnevushev ¿ Kravtsov, 1961). No entanto, uma outra hipótese (Bobryevich et al., 1959), as considera como resultado de radioatividade natural. A presença de figuras superficiais circulares (microdiscos) com pequena cavidade situada exatamente no centro parece estar associada a estas inclusões (Prancha IVf), o que talvez apóie a suposição da radioatividade.

\section{CONCLUSÕES}

A paragênese secundária, revelada pelos satélites, foi exaustivamente estudada por Hussak (1917), quando descreveu 56 espécies mineralógicas que ocorrem juntamente com o diamante, em jazidas aluvionares. Esta paragênese, que parece mais ligada a rochas metamórficas ou magmáticas ácidas, e ainda o fato de se terem encontrado inclusões de quartzo em diamantes brasileiros (Colony, 1923), fizeram com que se afastasse a hipótese da origem ultrabásica (Guimarães, 1934). No entanto, Hussak (1917), já havia ressaltado a casualidade destas associações, devidas simplesmente à semelhança das densidades dos minerais constituintes.

Os minerais satélites identificados no presente trabalho: quartzo, calcedônia, limonita, pirita, zircão, ilmenita, rutilo, granada, magnetita e cromita, foram já citados por Hussak (1917). Obser- vou-se, entretanto, a predominância de uma ou outra destas espécies, de depósito para depósito, fato também notado por Hussak.

\section{Paragênese primária}

A paragênese primária, obtida pelas inclusões singenéticas do diamante, pode indicar, com maior segurança, a natureza da rocha matriz, pois êstes minerais, muitas vêzes orientados epitàxicamente no hospedeiro, foram englobados durante a sua cristalização.

A associação dos minerais singenéti$\cos$, identificados como inclusões nos diamantes do Triângulo Mineiro: olivina (forsterita), granada (piropo) e cromoespinélio (magnesiocromita), é possível sòmente em rochas ultrabásicas (Deer et al., 1962), revelando, portanto, um ambiente bem diverso do sugerido pela associação secundária. 
Tabela 20 - Parâmetros unitários das inclusões de diamante

\begin{tabular}{lcccc}
\hline \multirow{2}{*}{ Inclusão } & $\begin{array}{c}\text { Parâmetro } \\
\text { Unitário }\left(\begin{array}{c}0 \\
\AA\end{array}\right)\end{array}$ & África & URSS & $\begin{array}{c}\text { Triângulo } \\
\text { Mineiro }\end{array}$ \\
& $\mathrm{a}_{0}$ & $4,73-4,74$ & $4,70-4,78$ & $4,75-4,77$ \\
Olivina & $\mathrm{b}_{0}$ & $10,21-10,22$ & $10,25-10,32$ & $10,19-10,23$ \\
& $\mathrm{c}_{0}$ & $5,99-6,91$ & $5,99-6,05$ & $5,98-6,01$ \\
\multirow{2}{*}{ Granada } & $\mathrm{a}_{0}$ & $11,50-11,65$ & $11,51-11,84$ & $11,51-11,65$ \\
Cromita & $\mathrm{a}_{0}$ & $8,29-8,5$ & $8,28-8,31$ & $8,30-8,35$ \\
\hline
\end{tabular}

A pentlandita, considerada por Harris (1968) como inclusão epigenética e originada pela exsolução de sulfetos mais estáveis a pressões elevadas, é também encontrada em rochas ultrabásicas, juntamente com a pirrotita, o que indica ocorrência de fenômeno análogo .

\section{Estudo comparativo}

Os diamantes do Triângulo Mineiro são, sob o ponto-de-vista morfológico, muito semelhantes aos diamantes aluvionares da África (Oubangui-Chari) (Polinard, 1923) e URSS (Sibéria) Prokopchuk et al., 1964), onde também se verifica a predominância de cristais rombododecaédricos, com arestas curvas e faces arredondadas.

$\mathrm{O}$ mesmo se observa quanto às figuras de superfície. As feições superficiais mais freqüentes, nos diamantes do Triângulo, são também comuns em cristais de outras procedências. No entanto, algumas destas figuras (Prancha $\mathrm{II} e \mathrm{e}$ III a ), não foram ainda descritas em diamantes de outras localidades.

As propriedades espectroscópicas (absorção ao IV ou fluorescência ao UV) são também análogas às de outros diamantes e talvez a maior ocorrência de diamantes do tipo $\mathrm{Ib}$ entre as amostras do Triângulo, seja um ponto de distinção importante, pois pode indicar uma cristalização mais rápida, não permitindo a disposição do nitrogênio em plaquetas (Du Preez e Raal, 1965). No entanto, esta conclusão deve ser confirmada por estudos posteriores, que possibilitem maior certeza estatística desta frequiência anômala.

A mesma semelhança se verifica com relação às inclusões minerais. $\mathrm{Na} \mathrm{Ta}$ bela 20 , pode-se observar a correspondência dos parâmetros unitários das inclusões de diamantes russos e sul-africanos, ao lado das mesmas constantes, determinadas nas amostras do Triângulo Mineiro.

\section{Considerações sôbre a origem}

A paragênese primária e a grande analogia com os diamantes de outras ocorrências no estrangeiro, cuja origem já está estabelecida, sugere que os diamantes do Triângulo tenham igualmente origem semelhante, e a ocorrência de rochas ultrabásicas na região (Formação Patos), poderia talvez ligar-se, direta ou indiretamente, aos processos genéti$\cos$ do diamante.

A presença de formas arredondadas, denotando a dissolução natural do diamante, pode indicar, de outro lado, que a composição química do magma original deva ter-se alterado, tornando o ambiente suficientemente oxidante, propiciando a corrosão. As mesmas formas poderiam também ter-se originado por flutuações da pressão, durante o processo de desenvolvimento.

Podem-se, ainda, estimar as condições de pressão e temperatura, no momento da cristalização, através da paragênese primária. A ocorrência, num mesmo hospedeiro, de cristais de olivina, ao lado 
de granada ou cromoespinélio, faz sugerir que o sistema:

forsterita +espinélio + coesita $\leq$ - piropo esteja em equilíbrio, o que se pode confirmar, também, pelas observações de Harris (1968). Êste autor já havia notado, além das associações acima citadas, a ocorrência de olivina, juntamente com enstatita, o que indica o equilíbrio 2 forsterita $\longleftrightarrow$ coesita + enstatita

A variedade polimórfica da sílica estável a altas pressões, encontrada em diamante africanos, deve ocorrer também nos diamantes do Triângulo Mineiro.

Desta forma, a curva de equilíbrio, construída com base na equação termodinâmica

$$
\Delta \mathrm{G}_{\mathrm{T}}^{\mathrm{P}}=(\Delta \mathrm{H})_{298}^{0}-\mathrm{T}(\Delta \mathrm{S})_{298}^{0}+\mathrm{P} \Delta \mathrm{V}=0
$$

onde:

$\Delta \mathrm{G}_{\mathrm{T}}^{\mathrm{P}}=$ entalpia livre

$$
\begin{aligned}
(\Delta \mathrm{H})_{298}^{0} & =\text { diferença de entalpia de reação } \\
(\Delta \mathrm{S})_{298}^{0} & =\text { diferença de entropia de reação } \\
\Delta \mathrm{V} & =\text { diferença de volumes molares, }
\end{aligned}
$$

pode fornecer as condições de pressão e temperatura sob as quais o diamante se formou.

Infelizmente, as constantes termodinâmicas do piropo, ainda não citadas na literatura, impediu estimar estas condições. O cálculo efetuado com as constantes correspondentes à grossulária, acusou pressões e temperaturas absurdas, extremamente elevadas. Contudo, as pressöes ideais requeridas para a síntese do piropo, ao redor de 10 a 30 Kbars (Deer et al., 1962), podem indicar que o equilíbrio considerado sòmente se verifique em pressões anàlogamente altas, o que concorda com as condições necessárias para a síntese do diamante.

\section{AGRADECIMENTOS}

A realização dêste trabalho tornou-se possível com a colaboração de muitos - pessoas e instituições - que, direta ou indiretamente, auxiliaram durante a sua execução, razão pela qual o autor deseja, aqui, registrar os seus agradecimentos e, em especial, ao orientador do presente, Prof. Dr. William Gerson Rolim de Camargo, da Cadeira de Mineralogia da Faculdade de Filosofia, Ciências e Letras da Universidade de São Paulo, não só pela orientação, como também pela dedicação e incentivo, durante o curso de formação e estágios de aperfeiçoamento.

Ao Prof. Waldemar Saffioti, do Departamento de Química da Faculdade de Filosofia, Ciências e Letras de Ara- raquara, somos imensamente gratos pelas valiosas críticas e sugestões, além de contribuir para a ręalização de nosso estágio, junto à Cadeira de Mineralogia da Faculdade de Filosofia, Ciências e Letras da Universidade de São Paulo. Devemos também assinalar, aqui, a compreensão irrestrita dos colegas, tanto do Departamento de Química da Faculdade de Filosofia, Ciências e Letras de Araraquara, como os da Cadeira de Mineralogia da Faculdade de Filosofia Ciências e Letras da Universidade de São Paulo, que nos aliviaram de tôda a carga burocrátịca, durante a execução das pesquisas .

Contribuiram com sugestôes oportunas, o Prof. Dr. Raymond Kern, da 
Atômica de São Paulo; Drs. Kenkichi Fujimori e José Vicente Valarelli, da Cadeira de Mineralogia da Faculdade de Filosofia, Ciências e Letras da Universidade de São Paulo, e Químico Antonio Carlos Massabni, da Faculdade de Filosofia, Ciências e Letras de Araraquara, aos quais queremos externar o nosso reconhecimento.

O Prof. Dr. Arahy Badini Tavares, do Departamento de Química da Faculdade de Filosofia, Ciências e Letras de Araraquara, auxiliou no estudo interferométrico, facultando-nos, ainda, o seu laboratório. Na confecção dos diagramas de absorção IV contamos com a preciosa colaboração e orientação do Dr. Germinio Nazario e da Srta. Myrian Toledo, do Instituto Adolpho Lutz, e o Eng. ${ }^{\circ}$ Rolf Hundertmark, da Inbelsa S. A., foi o responsável pela análise na microssonda de Castaing.

Nas viagens de coleta de material ti- vemos a valiosa companhia do Geólogo Irineu Marques Souza e Sr. Italo Bello, do Departamento de Mineralogia e Petrologia da Faculdade de Filosofia, Ciências e Letras da Universidade de São Paulo. A tradução de original do idioma russo foi possível com a colaboração do Prof Dr. Salomão Tabak, do Departamento de Química da Faculdade de Filosofia, Ciências e Letras de Araraquara. A revisão do texto esteve a cargo de meu pai, Prof. Dr. Manoel Cerqueira Leite, a quem devemos, também, tôda a formação básica.

Os auxílios financeiros que tornaram possível o presente estudo foram cedidos pela Fundação de Amparo à Pesquisa do Estado de São Paulo (FAPESP), Conselho Nacional de Pesquisas (C.N.Pq) e pela Coordenação do Aperfeiçoamento de Pessoal de Nível Superior (CAPES), que auxiliou através de bolsa concedida ao autor.

\section{B I B L I O G R A F I A}

ASTM (1965) - American Society for Testing and Materials - X-Ray Powder Diffraction File Philadelphia, U.S.A.

AZAROFF, L. V. e BUERGER, M. J. (1959) The powder method in x-ray crystallography Mc Graw Hill Book Co. New York, 342 pp

BARBOSA, O. (1938) - O diamante Minas Gerais - Min. Met. v. III, p. 69.

BECKENKAMP, J. (1926) - Zur Symmetrie des Diamanten - N. Jahrb. Min. B.B. 54A, p. 63-71.

BERMAN, R. (1964) - Thermal properties of diamonds - Diamond Research 1964, pp. 10-13.

BEZRUKOV, G. N., BUTUZOV, V. P. e KOROLEV, D. P., (1966) - Some crystallographic features on synthetic and natural diamond - Acta Cryst. v. 21, p. A257.

BIJVOET, J. M. (1951) - Diamond (editor) Inorganic compounds, Section II, Structure Reports, v. 11, pp. 187-197.

BOBRYEVICH, A. P., BONDARENKO, M. N., KRASOV, L. M., SMIRNOV, G. I. e VURKEVICH, R. K. (1959) - Diamond deposits of Yakutya - State sci tech. Lit. on geol, and prot. min. Moscow - Min. Abs. v. 14, p. 461.

BOA NOVA, F. (1932) - Pesquisas de platina em Coromandel - Ser. Geol. Min. Relatório Anual do Diretor, ano de 1931, pp. 73-75.

BOVENKERK, H. P. (1961) - Some observations on the morphology and physical characteristics of synthetic diamond - Amer. Mineral. v. 46, pp. 952-963.
BRAGG, W. H. e BRAGG, W. L. (1913) - The structure of diamond - Proc. Roy. Soc. Lond. v. $89 \mathrm{~A}$, p. 277 - Citado por Williams (1932).

BUERGER, M. J. (1945) - The genesis of twin crystals - Amer. Mineral. v. 30, pp. 469-482.

BUERGER, M. J. (1956) - Elementary Crystallography - John Wiley e Sons, New York, 528 pp.

BUERGER, M. J. (1964) - The precession method in $\mathrm{x}$-ray crystallography - John Wiley e Sons, New York, 276 pp.

BUNTING, E. N. e VAN VALKENBURG, A. (1958) - Some properties of diamond - Amer. Mineral. v. 43 , pp. $102-106$.

CAMARGO, W. G. R. e SVISERO, D. (1966) - Uma nova câmara de pó para difração de raios $\mathbf{X}$ - An. Acad. Brasil. Ciênc., v. 40, pp. 71-75.

CAMARGO, W. G. R. e LEITE, C. R. (1967) Nova técnica para a determinaçāo do retículo recíproco na câmara de precessâo - Ciência e Cultura, v. 19, p. 254.

CAMARGO, W. G. R. e LEITE, C. R. (1968) Inclusôes em diamantes brasileiros - olivina - An. Acad. Brasil. Ciênc., v. 40, Suplemento, pp. $89-92$.

CAMARGO, W. G. R. e LEITE, C. R. (1969) - Olivine epitaxy in Brazilian diamonds - VII International Congress of Crystallography, Stony Brook, New York, U.S.A.

CAMARGO, W. G. R. e INGLEZ, A. G. (1967) Determination of unit cell dimensions by a 
graphic analytical method - Annual Meeting, Am. Cryst. Ass., Atlanta, Georgia.

CAMARGO, W. G. R., LEITE, C. R. e SOUZA, I. M. (1969) - Determinação precisa de parâmetros unitários na câmara de precessão (no prelo).

CAMPOS, L. F. G. de (1891) - Jazidas diamantiferas de Agua Suja (Bagagem), Minas Gerais Topografia Cia. Ed. Fluminense, Rio de Janeiro, 52 pp. - Citado por Derby (1898).

CATICHA-ELLIS, S. e COCHRAN, W. (1958) - The $\mathrm{x}$-ray diffraction spikes of diamond - Acta Cryst., v. 11, pp. 245-249.

CHARETTE, J. J. (1961) - Infrared spectra of synthetic diamond - Journ. Chem. Phys., v. 35 pp. 1906-1907.

CHESLEY, F. J. (1942) - Investigation of minor elements in diamond - Amer. Mineral., v. 27, pp. 20-36.

COLONY, R. J. (1923) - An unusual quartz-diamond intergrowth Amer. Journ. Sci., 5th series, v. 5 , pp. 400-403.

CUSTERS, J. F. H. (1952) - Physica, v. 18, p. 489 - Citado por Mitchell (1964).

DANA, E. S. (1920) - The System of Mineralogy: Descritive Mineralogy - Sixth edition - New York, John Wiley e Sons, $1.134(+310)$ pp.

DEER, W. A., HOWIE, R. A. e ZUSSMAN, J. (1952) - Rock forming minerals, v. I, John Wiley e Sons. New York, 333 pp.

DENNING, R. M. (1953) - Directional grinding hardness in diamond - Amer. Mineral., v. 38, pp. $108-117$ e v. 40 , pp. $186-191$.

DERBY, O. A. (1882) - Modes of occurrence of the Diamond in Brazil - Amer. Journ. Sci., 3rd series, v. 24 , pp. $34-42$.

DERBY, O. A. (1898) - Brazilian evidence on the genesis of the diamond - Journ. Geol., v. 6, pp. 121-146.

DU PKEEZ, L. e RAAL, F. A. (1965) - Nitrogen in diamond - Diamond Research 1965, pp. 6-9.

ELLIOT, R. J. (1960) - Proc. Phys. Soc., v. 76, p. 787 - Citado por Du Prrez e Raal (1965).

ERGUN, S. e ALEXANDER, L. E. (1967) - Hexagonal diamonds in meteorites - Science, v. 156 , pp. 1170-1771. - Ind. Diam. Abst., v. 28, p. 183.

EPPLER, W, F, (1961) - Inclusions in diamond - Journ. Gemmology, v. 8, pp. 1-3 - (Gemologia, n. 26, pp. 3-15).

EVANS, T. e PHAAL, C. (1962) - Imperfections in type I and type II diamonds - Proc. Roy. Soc. Lond., v. 270-A, pp. 538-552.

FERSMAN, A. von e GOLDSCHMIDT, V. (1911) - Der Diamant - Carl Winters, Heidelberg, 274 pp. - Citado por Williams (1932).

FISCHER, R. B. (1961) - The "Balas" form of diamond - Nature, v. 189, p. 50.

FREYBERG, B. von (1932) - Ergbnisse geologischer Forschugen in Minas Geraes (Brasilien) - N. Jahrb. Min. Geol. Sond. II, XI, p. 401 (Resultado das pesquisas geológicas em Minas Gerais - XIX Congresso Brasileiro de Geolo- gia - Simpósio das formaçōes eopaleozóicas do Brasil, 1965 - Edição mimeografada traduzida por J. M. Campos).

FREYBERG, V. von (1934) - Die Bodenschätze des Staates Minas Geraes (Brasilien) - E. Schroeizerbart'sche Verlagsbuchhandlung, Sttutgart, $453 \mathrm{pp}$.

FRIEDEL, G. (1923) - Sur les inclusions noires contenus dans les diamants du Cap. Compt. Rend. Acad. Sci. Paris, v. 177, pp. 1085-1087 Min. Abst., v. 2, p. 234

FRIEDEL, G. (1932) - Contribuition à l'étude du diamant - Zeits. Krist. v. 83 , pp. $42-55$.

FUTERGENDLER, S. I. (1956) - The study of inclusions in diamonds by the method of $\mathrm{x}$-ray analysis - Zap. Vses. Miner. Obshch. v. 85, pp. 568-569, Min. Abst., v. 14, p. 121.

FUTERGENDLER, S. I. (1958) - X-ray study of solid inclusions in diamonds - Soviet. Phys. Crystallography, v. 3, pp. 494-497.

FUTERGENDLER, S. I. e FRANK-KAMENETSKII, V. A. (1961) - Oriented growth of olivine, garnet and chrome-spinel in diamond - Mem. All-Union Min. Soc., v. 90, pp. 230-236, Min Abst., v. 16, p. 437.

GIARDINI, A. A. e MITCHELL, R, S. (1953) Oriented olivine in diamonds - Amer. Mineral. v. 38, pp. $136-138$.

GNEVUSHEV, M. A. e NIKOLAEVA, E. S. (1958) - Diamonds of Yakutia - Min. Sbornik Geol. Soc. Lvov, v. 12 , pp. $440-442$, Min. Abst., v. 18 , p. 102.

GNEVUSHEV, M. A. e NIKOLAEVA, E. S. (1961) - Trudy. Ya. F.S.O. Akad. Nauk. SSSR Serv. Geol., pp. 97-105 - Citado por Harris (1968).

GNEVUSHEV, M. A. e KRAVSTOV, Ya. M. (1961) - The composition of impurities in Ural and Yakutsk diamonds - Doklady Acad. Sci. URSS Earth Sci. Sect. v. 130, pp. 154-156.

GNEVUSHEV, M. A. e FUTERGENDLER, S. I. (1963) - Zap. Vses. Obshch., v. 92, p. $617-$ Citado por Harris, 1968.

GOLDSCHMIDT, V. (1916) - Atlas der Krystallformen, v. III - Carl Winters, Heidelberg.

GUBELIN, E. (1952) - Inclusions in diamond Journ. Gemmology, Lond., v. 3, pp. 175-187.

GUIMARAES, D. (1931) - Petrologia e mineralogia - Serv. Geol. Min., Relatório Anual do Dire tor, Ano 1930, pp. 25-28.

GUIMARAES, D. (1932) - Sôbre a rocha matriz do diamante de Minas Gerais, Brasil - An. Acad. Brasil. Ciênc., v. 4, pp. 173-176.

GUIMARÃES, D. (1934) - A margem de "os satélites do diamante" - Monogr. Serv. Geol. Minas Gerais, n. 2, 59 pp.

GUimaRAes, D. (1965) - Princípios da metalogênese e geologia econômica do Brasil - Dep. Nac. Prod. Min. (DFPM), Bol. 121, pp. 540579.

HALPERIN, A. (1956) - Densities of trigons and ultra-violet absorption of diamonds - Acta Cryst., v. 9, pp. 265-268.

HANAY, J. B. $(1880)$ - Proc. Roy. Soc., v. 30 p. 188 - Citado por Simon (1968b) 
HARRIS, J. W. (1966) - The relative orientation of solid mineral inclusions in diamond - IMA Simposia Proceedings, pp. 163-168.

HARRIS, J. W., HENRIQUES, R. e MEYER, H. O. A. (1966) - Orientation of silicate inclusions in natural diamonds - Acta Cryst., v. 21, p. A259.

HARRIS, J. W. (1968) - The recognition of diamond inclusions - Part I (Syngenetic inclusions), Ind. Diam. Rev., v. 28, pp. $402-410$. Part. II (Epigenetic inclusions), Ind. Diam. Rev., v. 28 , pp. $458-461$.

HARTMAN, P. (1953) - Relations between structure and morphology of crystals - Tese de Doutoramento, Univ. Groningen, $158 \mathrm{pp}$.

HARTMAN, P. (1954) - A discussion on (oriented olivine inclusions in diamond" - Amer. Mineral., v. 39, pp. 674-675.

HARTMAN, P. e PERDOK, W. G. (1955) - Relations between morphology and structure of crystals - Acta Cryst., v. 8, pp. 49-52, 521524 e $525-529$.

HASUI, Y. (1967) - Geologia das formaçōes cretáceas do Oeste de Minas Gerais - Tese de Doutoramento - Escola Politécnica da U.S.P., $87 \mathrm{pp}$.

HOERNI, J. A. e WOOSTER, W. A. (1955) - The X-ray anomalous reflexions from diamond Acta Cryst., จ. 8, pp. 187-194.

HUSSAK, E. (1894) - Sôbre o depósito diamantífero de Água Suja, perto de Bagagem, MG - Com. Exp. Planalto Central do Brasil, Relatório, Anexo 5, p. 281, Rio de Janeiro Citado por Derby (1898).

HUSSAK, E. (1906) - Uber die Diamantlager stätten in Westem des Staates Minas Geraes und der angrenzenden Staaten São Paulo und Goyaz, Brasilien - Zeitschr. f.prakt. Geol. XIV, pp. 318-333 - Citado por Freyoerg (1932).

HUSSAK, E. (1917) - Os satélites do diamante - Serv. Geol. Min., Riu de Janeiro, 56 pp. - Trad. de J. B. de Araujo Ferraz.

KAISER, W. e BOND, W. L. (1959) - Phys. Rev., v. 115 , p. 857 - Citado por Du Preez e Raal (1965).

KRAUS, E. H. e SLAWSON, C. B. (1939) - Variation of hardness in the diamond - Amer. Mineral., v. 24 , pp. $661-676$

LANG, A. R. (1959) - The projection topograph: a new method in X-ray microradiography Acta Cryst., v. 12, pp. 249-250.

I.EINZ, V. (1939) - Der Diamant "Presidente Vargas" - Zentr. Min. Abt. A, p. $99-$ (Min. Met., v. III, pp. 185-186).

LEINZ, V. e SOUZA CAMPOS, J. E. (1968) Guia para determinação de minerais - Comp. Ed. Nacional, 4.a ed. 140 pp.

LEONARDOS, O. H, e SALDANHA, R. (1939) Diamante "Darcy Vargas" e outros grandes diamantes brasileiros - Bol. Fac. Fil. Ciênc. Let. USP n. 18 (Mineralogia 3), pp. 3-25.

LEONARDOS, O. H. (1956) - Recursos minerais do Triângulo Mineiro - Min. Met., v. 24, pp. 11-77.
MAACK, R. (1926) - Eine Forschungsreise über das Hochland von Minas Geraes zum Paranahyba - Zeits. d. Gesel. f. Erd. Berlim, pp. 310-323 - Citado por Freyberg (1932).

MAACK, R. (1932) - Uber den geologischen Bau Hochplateaus von West Minas - Zeits. d. Gesel. f. Erd., Berlim, Heft 7/8, pp. 299-306 - Citado por Guimarāes (1934).

MATHUR, S. M. (1962) - Geology of the Panna diamond deposits - Rec. Geol. Survey India, v. 87 , pp. $787-818$, Min. Abst., v. 16, p. 48.

MYKOLAJEWYCZ, R., KALNAJS, J. e SMAKULA, A. (1964) - High precision density determinations of natural diamonds - Journ. Appl. Phys., v. 35 , pp. $1773-1778-$ Min. Abst., v. 17, p. 164.

MILLEDGE, H. J. (1961) - Coesite as an inclusion in G. E. C. synthetic diamonds - Nature, v. 190 , p. 1181.

MITCHELL, E. W. J. (1964) - The optical properties of diamond - Diamond Research 1964, pp. 13-16.

MOISSAN, H. (1894) - Comp. Rend. Acad. Sci. Paris, v. 118 , p. 320 - Citado por Simon (1968b).

NOMARSKI, G. e WEILL, A. R. (1955) - Application à la métallographie des méthodes interferentielles à deux ondes polarisées - Revue de Métallurgie, v. 52, pp. 121-134 - Catálogo Reichert (Viena), polarization interferometer after Nomarski.

OMAR, M. e KENAWI, M. (1957) - The etching of diamonds by low pressure oxigen - Phil. Mag., v. 8, pp. 859-863, Min. Abst., v. 14, p. 122.

ORLOV, Yu. L. (1959) - Syngenetic and epigenetic inclusions in the crystals of diamond Trans. Min. Mus. Acad. Sci. URSS, v. 10, pp. 103-120.

PALACHE, C. (1932) - Multiple twins of diamond and spharelite - Amer. Mineral., v. 17, pp. 360-361.

PATEL, A. R. e RAMACHANDRAN, N. (1968) Growth spirals on octahedral faces of synthetic diamond - Ind. Diam. Rev., v. 28, pp. 127-129.

PATEL, A. R. e AGARWAL, M. K. (1965) - Microestuctures on Panna diamond surfaces Amer. Mineral., v. 50, pp. 124-131.

POEN, O. (1959) - Microprojection with x-rays - Martinus Nijhoff, The Hague, 132 pp.

POINTDEXTER, E. (1955) - Piezobirefringence in diamond - Amer. Mineral., v. 40, pp. 10321054.

POLINARD, E. (1932) - Les formes cristallines des diamants de L'Oubangui-Chari - Bull. Soc. Fra. Min., v. 55, pp. 213-235.

PROKOPCHUK, B. I., SERGIYENKO, V. M. e MAKAROVA, N. V. (1964) - Diamonds from the North-eastern Siberian plataform (diamond bearing region near the Lena) - Doklady Akad. Nauk. SSSR, v. 154, pp. 101-103.

RAAL, F. A. (1957) - A spectrographic study of the minor element content of diamond - Amer. Mineral., v. 42, pp. 354-361. 
REIS, E. (1959) - Os grandes diamantes brasileiros - Div. Geol. Min. DNPM, n. 191, 65 pp.

RIMANN, E. (1915) - Uber Kimberlit und Alnöit in Brasilien - Tscherm. Min. Petr. Mitt., v. 33, pp. 244-262.

RIMANN, E. (1917) - Uber das Muttergestein der Diamanten Brasiliens - Tscherm. Min. Petr. Mitt., v. 34, pp. 255-261.

RIMANN, E. (1931) - Uber das Muttergestein der Diamanten von Minas Geraes (Brasilien) Fortschr. Min. Krist. Petr., v. 16, pp. 93-96.

ROBERTSON, R., FOX, J. J. e MARTIN, A. E. (1934) - Two types of diamond - Phil. Trans. Roy. Soc., v. A 232, p. 463 - Citado por Mitchell (1964).

ROSENFELD, J. L. (1950) - Determination of al principal indices of refraction on difficultly oriented minerals by direct measurement Amer. Mineral., v. 35, pp. 902-905.

ROSSINI, F. D., WAGMAN, D. D., EVANS, W. H., LEVINE, S. e JAFFE, I. (1952) - Nat. Bur. Standard, Circular 500 - Citado por Simon (1968b).

SALDANHA, R. (1941; - O diamante Coromandel - Bol. Fac. Fil. Ciênc. Let, USP. n. 21 (Mineralogia 4), pp. 15-23.

SALDANHA, R. (1942) - O diamante "Governador Valadares" - Bol. Fac. Fil. Ciênc. Let., USP, n. 30 (Mineralogia 5), pp. 17-23.

SEAL, M. (1962) - The surface structure of diamonds - Gems and Gemmology, v. 10, pp. 309 . 314 .

SEAL, M. (1965) - Structure in diamonds as revealed by etching - Amer. Mineral,, v. 50, pp. 105-123.

SEAL, M. (1968) - Diamond - as a crystal and as an industrial material - Ind. Diam. Rev., v. 28 , pp. 104-110.

SHAH, C. J. e LANG, A. R. (1963) - An unusual distribution of precipitates in a diamond Min. Mag., v. 33, pp. 594-599.

SHARP, W. E. (1966) - Pyrhotite: a common inclusion in South-African diamonds - Nature, v. 211, pp. 402-403.

SIMON, B. (1968a) - Contribuition à l'étude de la formation des macles de croissance - Tese de Doutoramento (Primeira Tese), Universidade de Marseille, 149 pp.

SIMON, B. (1968b) - La synthese du diamant Tese de Doutoramento (Segunda Tese), Universidade de Marseille, 11 pp.
SLAWSON, C.B. (1950) - Twining in the diamond - Amer. Mineral., v. 35, pp. 193-206.

SMITH, W. V., SOROKIN, P. P., GELLES, I. L. e LASHER, G. J. (1959) - Phys. Rev., v. 115 , p. 1546 - Citado por Du Preez e Raal (1965).

SPENCER, L. J. (1924) - An inclusion of magnetite in diamond - Min. Mag., v. 20, pp. 245247.

SRIRAMADAS, A. (1957) - Diagrams for the correlation of unit cell edges and refractive indices with the chemical composition of garnets - Amer. Mineral., v. 42, pp. 294-298.

SUTHERLAND, G. B. B. M., BLACKWELL, P. E. e SIMERAL, W. G. (1954) - The problem of the two types of diamond - Nature, v. 174 pp. 901-904.

SUTTON, J. R. (1921) - Inclusions in diamond from South Africa - Min. Mag., v. 19, pp. 208-210.

TOLANSKY, S. e SUNAGAWA, I. (1959) - Spiral and other growth forms of synthetic diamonds: a distinction between natural and synthetic diamonds - Nature, v. 184, pp. 1526-1527.

TOLANSKY, S. (1960) - Surface Microtopography - Longmans, London, 296 pp.

TOLANSKY, S. (1966) - Birrefringence of diamond - Nature, v. 211, pp. 158-160.

TOLANSKY, S. e KOMATSU, H. (1967) - Abundance of type II diamonds - Science, v. 157 , pp. 1173-1175, Ind. Diam. Abst., v. 28, p. 183.

UREY, H. C., MELE, A. e MAYEDA, T. (1957) - Diamonds in stone meteorites - Geochim. Cosm. Acta, v. 13 , pp. 1-4.

VALARELLI, J. V. (1963) - Morfologia de um cristal de diamante - Gemologia, n. 31, pp. $1-6$.

WAGNER, P. A. (1914) - The diamond fields of Southern Africa - Johannesburg - Citado por Harris (1968).

WEDEPHOL, P. T. (1957) - Electrical and optical properties of type Ilb diamonds - Proc. Phys. Soc. Lond., v. 70B, pp. 177-185.

WILLIAMS, A. F. (1932) - The genesis of diamond. V. II - Ernest Benn, London, $536 \mathrm{pp.}$

YODER, H. S. e SAHAMA, T. H. G. (1957) Olivine $\mathrm{x}$-ray determinative curve - Amer, Mineral., v. 42, pp. 475-491. 